\title{
Strontium Distribution Coefficients of Basalt Core Samples from the Idaho National Engineering and Environmental Laboratory,
}

Idaho

By Joseph J. Colello, U.S. Geological Survey; Jeffrey J.

Q851

Rosentreter, Idaho State University; Roy C. Bartholomay and

Michael J. Liszewski, U.S. Geological Survey

U.S. GEOLOGICAL SURVEY

Water-Resources Investigations Report 98-4256

Prepared in cooperation with

the U.S. DEPARTMENT OF ENERGY 


\section{U.S. DEPARTMENT OF THE INTERIOR BRUCE BABBITT, Secretary}

\section{U.S. GEOLOGICAL SURVEY \\ Charles G. Groat, Director}

Any use of trade, product, or firm names is for descriptive purposes only and does not imply endorsement by the U.S. Government.

For additional information write to:

U.S. Geological Survey

INEEL, MS 1160

P. O. Box 2230

Idaho Falls, ID 83403-2230
Copies of this report can be purchased from:

U.S. Geological Survey

Information Services

Box 25286, Denver Federal Center

Denver, CO 80225 


\section{DISCLAIMER}

This report was prepared as an account of work sponsored by an agency of the United States Government. Neither the United States Government nor any agency thereof, nor any of their employees, make any warranty, express or implied, or assumes any legal liability or responsibility for the accuracy, completeness, or usefulness of any information, apparatus, product, or process disclosed, or represents that its use would not infringe privately owned rights. Reference herein to any specific commercial product, process, or service by trade name, trademark, manufacturer, or otherwise does not necessarily constitute or imply its endorsement, recommendation, or favoring by the United States Government or any agency thereof. The views and opinions of authors expressed herein do not necessarily state or reflect those of the United States Government or any agency thereof. 


\section{DISCLAIMER}

Portions of this document may be illegible in electronic image products. Images are produced from the best available original document. 


\section{CONTENTS}

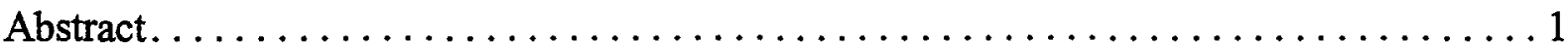

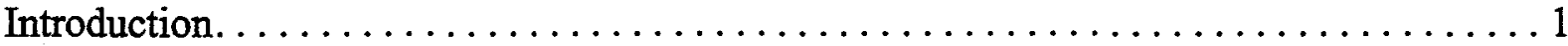

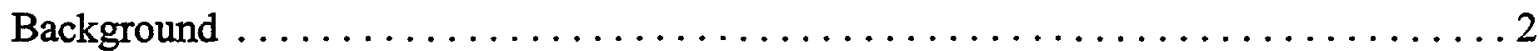

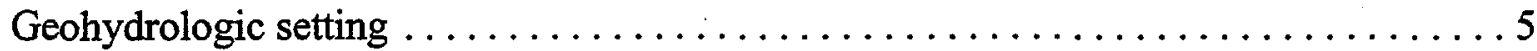

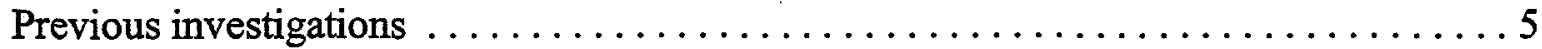

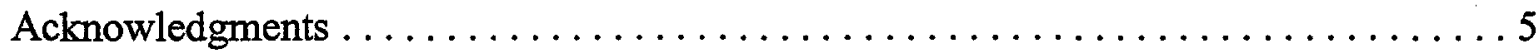

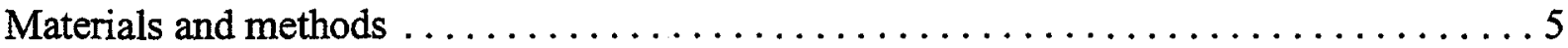

Collection, description, and preparation of basalt core samples $\ldots \ldots \ldots \ldots \ldots \ldots . \ldots$

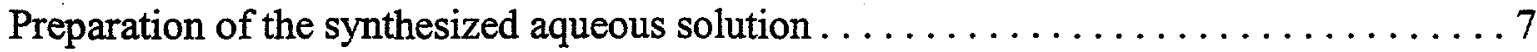

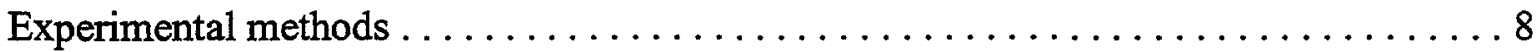

Derivation of the strontium distribution coefficient using the linear sorption isotherm

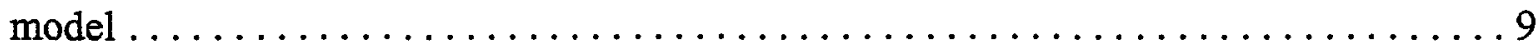

Strontium distribution coefficients of basalt core samples.................. 9

Conclusions. . . . . . . . . . . . . . . . . . . . . . . . . . . . . . 10

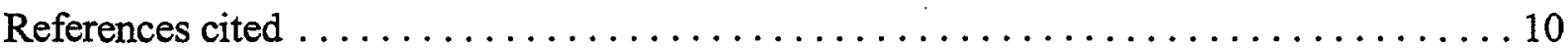

\section{FIGURES}

1. Map showing location of the Idaho National Engineering and Environmental Laboratory and selected facilities...............................

2. Map showing location of the Idaho Chemical Processing Plant, Test Reactor Area, and selected waste-disposal sites, Idaho National Engineering and Environmental

Laboratory ................................... 4

3. Map showing location of sites where basalt core samples were collected, Idaho National Engineering and Environmental Laboratory. . . . . . . . . . . . . . . . . . . 6

\section{TABLES}

1. Depths and descriptions of basalt core samples from the Idaho National Engineering and Environmental Laboratory. . . . . . . . . . . . . . . . . . . . . . . . . 13

2. Whole-rock analysis for selected major, minor, and trace elements of basalt samples from the Idaho National Engineering and Environmental Laboratory . . . . . . . . . 14

3. Brunauer-Emmett-Teller surface areas of selected basalt samples from the Idaho National Engineering and Environmental Laboratory $\ldots \ldots \ldots \ldots \ldots \ldots \ldots \ldots$

4. Target concentrations of alkalinity, aluminum, calcium, iron, magnesium, potassium, silica, sodium, strontium, and $\mathrm{pH}$ in the synthesized aqueous solutions used in the strontium batch experiments . . . . . . . . . . . . . . . . . . . . . . . 16

5. Concentrations of alkalinity, calcium, magnesium, potassium, silica, sodium, and strontium, and $\mathrm{pH}$ in samples collected from infiltration ponds at the Idaho Chemical Processing Plant

6. Basalt mass; initial and final aluminum, calcium, iron, magnesium, potassium, sodium, and strontium concentrations; initial and final conductivity and $\mathrm{pH}$; and measured distribution coefficients of synthesized solutions . . . . . . . . . . . . . . . . 17

7. Calculated and measured strontium distribution coefficients of basalt samples from the Idaho National Engineering and Environmental Laboratory . . . . . . . . . . . 65 
CONVERSION FACTORS AND ABBREVIATED UNITS

\begin{tabular}{lll}
\hline \multicolumn{1}{c}{ Multiply } & By & To obtain \\
\hline cubic centimeter $\left(\mathrm{cm}^{3}\right)$ & 0.06102 & cubic inch \\
centimeter $(\mathrm{cm})$ & 2.54 & inch \\
gram $(\mathrm{g})$ & 0.03527 & ounce \\
kilometer $(\mathrm{km})$ & 0.6214 & mile \\
square kilometer $\left(\mathrm{km}^{2}\right)$ & 0.3861 & square mile \\
meter $(\mathrm{m})$ & 3.281 & foot \\
becquerel per liter $(\mathrm{Bq} / \mathrm{L})$ & 27 & picocuries per liter \\
terra becquerel $(\mathrm{TBq})$ & 27 & curies \\
\hline
\end{tabular}

For temperature, degrees Celsius $\left({ }^{\circ} \mathrm{C}\right)$ can be converted to degrees Fahrenheit $\left({ }^{\circ} \mathrm{F}\right)$ by using the formula $\mathrm{F}=(1.8)(\mathrm{C})+32$.

Abbreviated units used in report: $\mathrm{K}_{\mathrm{d}}$ (distribution coefficient), $\mathrm{mg} / \mathrm{L}$ (milligrams per liter), $\mathrm{mL}$ (milliliter), $\mathrm{mL} / \mathrm{g}$, (milliliters per gram), $\mu \mathrm{g} / \mathrm{kg}$ (milligrams per kilogram), $\mu \mathrm{s} / \mathrm{cm}$ (microsiemens per centimeter), $\mathrm{m}^{2} / \mathrm{g}$ (meters squared per gram). 


\title{
Strontium Distribution Coefficients of Basalt Core Samples from the Idaho National Engineering and Environmental Laboratory, Idaho
}

\author{
By Joseph J. Colello, U.S. Geological Survey; Jeffrey J. Rosentreter, Idaho State \\ University; Roy C. Bartholomay and Michael J. Liszewski, U.S. Geological \\ Survey
}

\section{Abstract}

Strontium distribution coefficients $\left(\mathrm{K}_{\mathrm{d}} \mathrm{s}\right)$ were measured for 24 basalt core samples collected from selected sites at the Idaho National Engineering and Environmental Laboratory (INEEL). The measurements were made to help assess the variability of strontium $K_{d}$ 's as part of an ongoing investigation of strontium transport properties through geologic materials at the INEEL. The investigation is being conducted by the U.S. Geological Survey and Idaho State University in cooperation with the U.S. Department of Energy. Batch experiments were used to measure $\mathrm{K}_{\mathrm{d}}$ 's of basalt core samples using an aqueous solution representative of wastewater in waste-disposal ponds at the INEEL. Calculated strontium $\mathrm{K}_{\mathrm{d}}$ 's of the 24 basalt core samples ranged from $3.6 \pm 1.3$ to $29.4 \pm 1.6$ milliliters per gram. These results indicate a narrow range of variability in the strontium sorptive capacities of basalt relative to those of the sedimentary materials at the INEEL. The narrow range of the basalt $K_{d}$ 's can be attributed to physical and chemical properties of the basalt, and to compositional changes in the equilibrated solutions after being mixed with the basalt. The small $\mathrm{K}_{d}$ 's indicate that basalt is not a major contributor in preventing the movement of strontium-90 in solution.

\section{INTRODUCTION}

The transport and fate of waste constituents in geologic material is dependent on chemical and physical processes that govern the distribution of constituents between the solid, geologic, stationary phase and an aqueous mobile phase. This distribution often is quantified, at thermodynamic equilibrium, by an empirically determined parameter called the distribution coefficient $\left(\mathrm{K}_{d}\right)$. $\mathrm{K}_{d}$ 's can be used effectively to summarize the chemical factors that affect transport efficiency of groundwater constituents. Many transport models for radionuclides use $\mathrm{K}_{\mathrm{d}}$ 's to predict the extent to which the migration of the constituent will be lessened relative to the mean ground-water velocity (Bohn, 1985, p. 153-207; Sposito, 1989, p. 150155; Fetter, 1993, p. 117-127).

In 1949, the U.S. Atomic Energy Commission, which later became the U.S. Department of Energy (DOE), requested that the U.S. Geological Survey (USGS) describe the water resources of the area now known as the Idaho National Engineering and Environmental Laboratory (INEEL). The purpose of the resulting study was to characterize these resources before the development of nuclear-reactor testing facilities. The USGS since has maintained a monitoring network at the INEEL to determine hydrologic trends and to delineate the movement of facility-related radiochemical and chemical wastes in the Snake River Plain aquifer. As part of this effort, the USGS and Idaho State University (ISU), in cooperation with the DOE, are conducting a study to determine geochemical properties that affect strontium transport in basalt at the INEEL. The purpose of this study is to determine the fate and transport behavior of chemical constituents in wastewater discharged to infiltration ponds and to the Snake River Plain aquifer at the INEEL. Study objectives include assessing the variability of strontium $\mathrm{K}_{\mathrm{d}}$ 's in basalt at the INEEL.

This report presents experimentally derived strontium $\mathrm{K}_{d}$ 's of 24 basalt core samples collected 
from selected sites at the INEEL. Basalt core samples were mixed with synthesized aqueous solutions using batch experimental techniques to determine the strontium distributions between the solid and aqueous phases. The synthesized aqueous solutions were representative of wastewater in disposal ponds at the INEEL with respect to major cations and $\mathrm{pH}$. Strontium concentrations in the solutions were varied to define strontium sorption isotherms. Strontium $\mathrm{K}_{\mathrm{d}}$ 's were derived from the isotherms using the linear sorption model described by Fetter (1993, p. 117-119).

\section{Background}

The INEEL comprises $2,300 \mathrm{~km}^{2}$ of the eastern Snake River Plain in southeastern Idaho (fig.1). The INEEL was established in 1949 by the DOE for the development of peacetime atomicenergy applications such as nuclear-safety research, defense programs, and advanced energy concepts. More than 50 nuclear reactors have been operated at the INEEL since its inception. Facilities at the INEEL also are used to store nuclear waste, such as spent fuel rods from the U.S. Navy's nuclear fleet and other DOE sites, and wastes generated onsite.

Aqueous chemical and radiochemical wastes, including strontium- $\left.90{ }^{90} \mathrm{Sr}\right)$, have been discharged to wastewater-disposal ponds and wells at the INEEL since 1952. Prior to February 1984, much of the wastewater discharged at the Idaho Chemical Processing Plant (ICPP) was injected directly into the Snake River Plain aquifer through a deep injection well. Since 1984 , most of the wastewater has been discharged to unlined infiltration ponds. Some chemical constituents from wastewater may enter the aquifer indirectly following percolation from the infiltration ponds through sediments and basalt layers in the unsaturated zone (Pittman and others, 1988). Disposal of radioactive wastewater to the Test Reactor Area (TRA) radioactive-waste ponds ceased in August of 1993 and the ponds were remediated (Eddie Chew, U.S. Department of Energy, written commun., 1995). Radioactive wastewater at the TRA now is discharged to two lined evaporation ponds.

${ }^{90} \mathrm{Sr}$ is a radionuclide produced by the fission of uranium, has a half-life of 28.8 years, and decays through beta emission (Eisenbud, 1973, p. 83-97). The global deposition of ${ }^{90} \mathrm{Sr}$ is well documented (Eisenbud, 1973, p. 320-331). This radionuclide is present in ground water as the result of fallout from nuclear explosions and as a result of the waste-disposal practices used in the nuclear industry. Because of its tendency to concentrate uniformly throughout bone tissues, ${ }^{90} \mathrm{Sr}$ is a health hazard. The maximum contaminant level allowable in drinking water is $8 \mathrm{pCi} / \mathrm{L}(0.3 \mathrm{~Bq} / \mathrm{L})$ (U.S. Environmental Protection Agency, 1989, p. 551).

Approximately $5.6 \mathrm{TBq}$ of ${ }^{90} \mathrm{Sr}$ was discharged to the subsurface at the INEEL from the early 1950 's to 1995 , primarily at the ICPP and TRA facilities (Bartholomay and others, 1997, p. 30). Documented disposals include:

1.2 $\mathrm{TBq}$ of ${ }^{90} \mathrm{Sr}$ discharged into a pit at the ICPP during 1962-63 (Robertson and others, 1974, p. 119);

$0.9 \mathrm{TBq}$ of ${ }^{90} \mathrm{Sr}$ discharged to a disposal well and infiltration ponds at the ICPP (fig. 2) from 1952-95, of which approximately $0.02 \mathrm{TBq}$ was discharged to the waste disposal ponds (Bartholomay and others, 1995, p. 21; Bartholomay and others, 1997, p. 30); and

$3.4 \mathrm{TBq}$ of ${ }^{90} \mathrm{Sr}$ discharged to radioactivewaste disposal ponds at the TRA (fig. 2) from 1952-95 (Bartholomay and others, 1997, p. 30).

Concentrations of ${ }^{90} \mathrm{Sr}$ in perched ground water beneath the ICPP ranged from 0 to $0.63 \pm 0.07$ $\mathrm{Bq} / \mathrm{L}$ during 1991 through 1995. Concentrations of ${ }^{90} \mathrm{Sr}$ in perched ground water beneath the TRA ranged from 0 to $5.3 \pm 0.2 \mathrm{~Bq} / \mathrm{L}$ during the same period (Bartholomay, 1998, p. 16). Disposal of ${ }^{90} \mathrm{Sr}$ has resulted in a $10-\mathrm{km}^{2}$ plume within the eastern Snake River Plain aquifer beneath the ICPP (Bartholomay and others, 1997, p. 33) with concentrations greater than $0.3 \mathrm{~Bq} / \mathrm{L}$. In 1995 , concentrations of ${ }^{90} \mathrm{Sr}$ in water from wells completed in the Snake River Plain aquifer were as large as $2.8 \pm 0.1 \mathrm{~Bq} / \mathrm{L}$ (Bartholomay and others, 1997, p. 30). ${ }^{90} \mathrm{Sr}$ has not been detected within the eastern Snake River Plain aquifer beneath the TRA. This may, in part, be explained by the use of disposal ponds rather than the disposal well at this facility. Sorption processes in the unsaturated and perched-water zones beneath the disposal ponds 


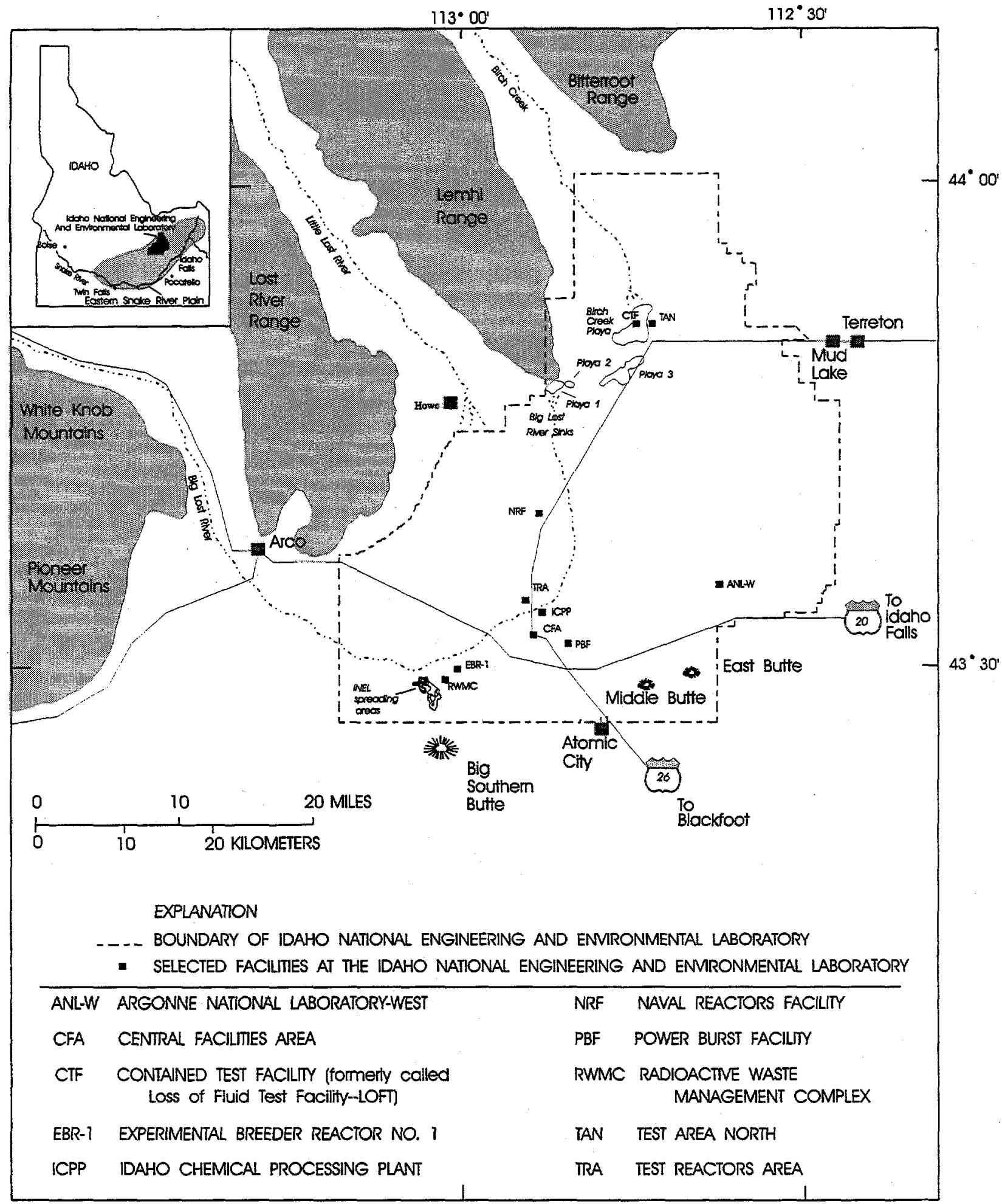

Figure 1. Location of the Idaho National Engineering and Environmental Laboratory and selected facilities. 


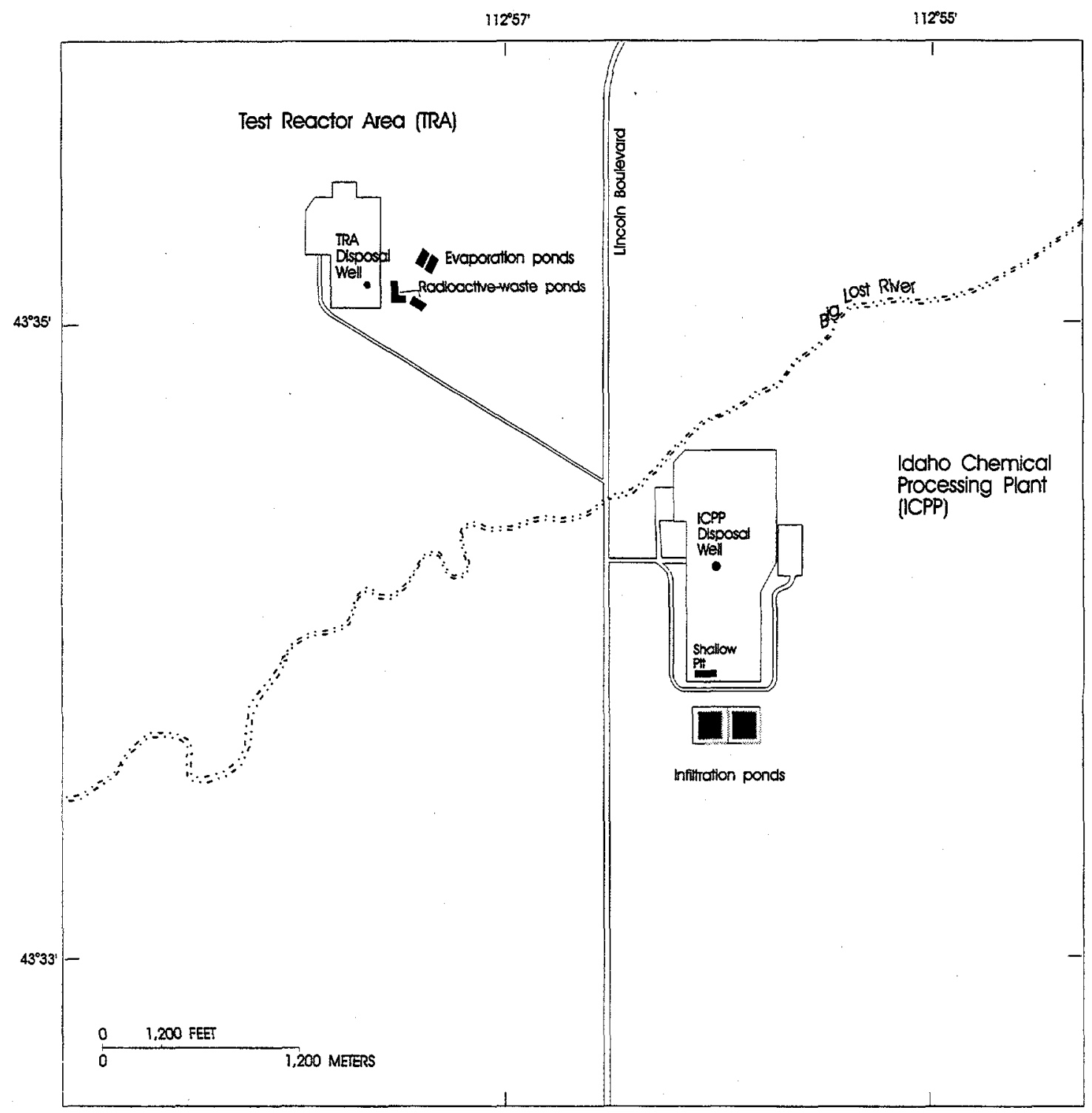

Figure 2. Location of the Idaho Chemical Processing Plant, Test Reactor Area, and selected waste-disposal sites, Idaho National Engineering and Environmental Laboratory. 
likely have lessened ${ }^{90} \mathrm{Sr}$ migration at the TRA. Also, more sediment is present beneath the TRA than beneath the ICPP (Anderson, 1991, p. 22-28).

\section{Geohydrologic Setting}

The eastern Snake River Plain is a northeasttrending structural basin about $320 \mathrm{~km}$ long and 80 to $110 \mathrm{~km}$ wide. The plain is underlain by a layered sequence of basaltic rocks and cinder beds intercalated with alluvial and lakebed deposits. Individual layers of basalt range from 3 to $15 \mathrm{~m}$ in thickness, although the average thickness may be from 6 to $8 \mathrm{~m}$ (Mundorff and others, 1964, p. 143). The sedimentary deposits consist mainly of lenticular beds of sand, silt, and clay, and lesser amounts of gravel. Locally, rhyolitic rocks and tuffs are exposed at the land surface or occur at depth. The basaltic rocks and intercalated sedimentary deposits combine to form the framework for the Snake River.Plain aquifer system, which is the main source of ground water on the plain. The depth to water in the aquifer system ranges from about $60 \mathrm{~m}$ below land surface in the northern part of the INEEL to more than $275 \mathrm{~m}$ in the southern part (Bartholomay and others, 1997, p. 20). The general direction of ground-water flow is from the northeast to the southwest. The INEEL obtains its entire water supply from the Snake River Plain aquifer.

\section{Previous Investigations}

Strontium $\mathrm{K}_{\mathrm{d}}$ 's of sediment collected from the INEEL have been reported by Hawkins and Short (1965), Schmalz (1972), Del Debbio and Thomas (1989), Newman and others (1996), Bunde and others (1997), Hemming and others (1997), Liszewski and others (1997), Bunde and others (1998), and Liszewski and others (1998). Strontium $K_{d}$ 's of basalt collected from the INEEL have been reported by Del Debbio and Thomas (1989) and Newman (1996). Strontium $\mathrm{K}_{d}$ 's of the Columbia River basalt have been reported by Barney (1981). Many researchers have studied strontium $K_{d}$ 's and the factors that affect them. A summary and review of available information published through 1976 of strontium and other radionuclide interactions with geologic material was compiled by Ames and Rai (1978).

\section{Acknowledgments}

The authors gratefully acknowledge the assistance and cooperation, laboratory space, and equipment, provided by the ISU Department of Chemistry, Dr. Dennis Strommen, Chairman. The authors are grateful to Mary Pace and Steven $R$. Anderson of the USGS for technical review of the manuscript.

\section{MATERIALS AND METHODS}

Experiments for measuring $\mathrm{K}_{d}$ 's required the collection and preparation of basalt core samples and the preparation of the synthesized aqueous solution. Once the samples and solution were prepared, they were combined in a reaction vessel and agitated using batch experimental techniques for a period of time sufficient for an apparent equilibrium to be reached. Then solutions were analyzed for dissolved-strontium content. The amount of strontium sorbed to the basalt was calculated from the difference between the initial and equilibrium solution concentrations multiplied by the volumeto-mass ratio. Sorption isotherms and $K_{d}$ 's then were calculated using the linear sorption isotherm model (Fetter, 1993, p. 118).

\section{Collection, Description, and Preparation of Basalt Samples}

Basalt core samples were collected during October and November of 1996 from archived cores housed at the INEEL lithologic core storage library (Davis and others, 1997). For this study, 24 basalt samples were collected from four corehole sites at the INEEL; USGS 123, WO-1, WO-2, and TAN CH1 (fig. 3). A general description of each sample is given in table 1. More detailed descriptions of basalt cores are given by Lanphere and others (1993) and Lanphere and others (1994). The geochemical compositions of the basalt samples are given in table 2, and Brunauer-Emmett-Teller (BET) surface areas of selected samples are given in table 3. Well USGS 123 is near the ICPP and contains ${ }^{90} \mathrm{Sr}$ concentrations in ground water above the MCL for drinking water (Bartholomay and others, 1997, p. 33). TAN CH1 is near Test Area North (TAN). At both of these facilities, radioactive wastewater containing ${ }^{90} \mathrm{Sr}$ have been dis- 


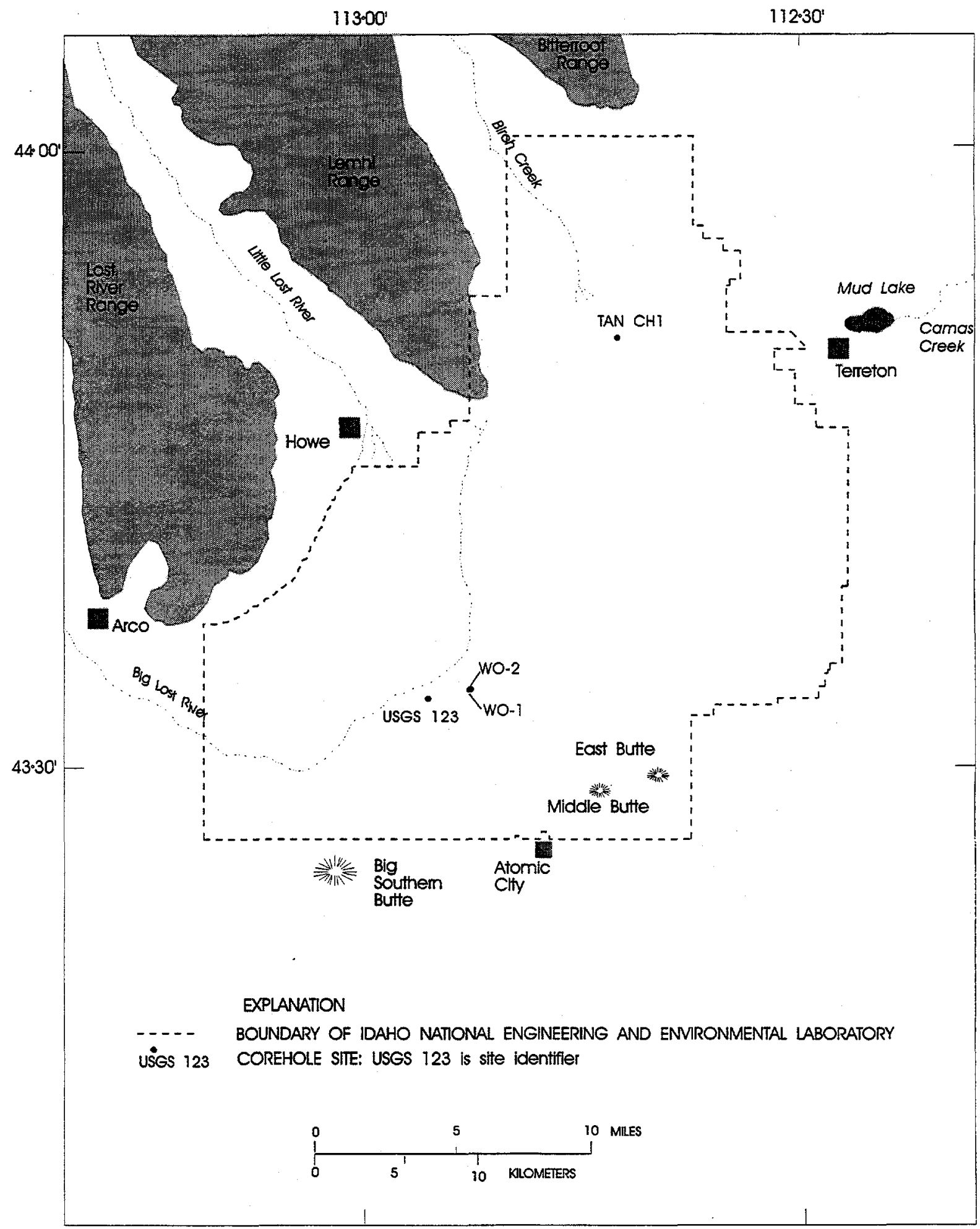

Figure 3. Location of sites where basalt core samples were collected, Idaho National Engineering and Environmental Laboratory. 
charged to the subsurface. Additional samples were collected from cores WO-1 and WO-2, which are located approximately $4 \mathrm{~km}$ hydraulically upgradient from the ICPP and are outside of the ${ }^{90} \mathrm{Sr}$ waste plume.

Representative 8-cm pieces of core were collected using a core splitter, placed into plastic bags, and then labeled and transported to ISU for preparation and analyses. Sample selection criteria for USGS 123 was based on the availability of samples from the top of every major basalt flow, emphasizing areas of vesicularity, sediment infill, secondary mineralization, and fracture zones because these are the main conduits for groundwater flow. Massive-basalt samples were collected at each corehole site for comparison with vesicular samples. Basalt samples from USGS 123 are from depths of $14,64,68,130,153,156,172$, $189,209,211$, and $221 \mathrm{~m}$. Two samples were collected from the 14-m depth because of major differences in vesicularity. Duplicate analyses were performed for the sample from the $211-\mathrm{m}$ depth. Special attention was given to the I Flow (Anderson, 1991) because it is the thickest and most extensive flow in the Snake River Plain aquifer at the INEEL.

Sample selection at cores from WO- 1 and WO-2 concentrated on major flows below the water table, especially the I Flow. Basalt samples from WO-1 are from depths of 141 and $146 \mathrm{~m}$. Basalt samples from WO-2 are from depths of $185,186,397,400$, and $520 \mathrm{~m}$.

Samples were collected at TAN CH1 to observe differences in basalt characteristics related to a contamination plume above sedimentary interbed Q-R (Anderson and Bowers, 1995). TAN CH1 also was selected because the basalt is much older than the basalt from the other three sites. One vesicular and three massive samples were collected. Basalt samples from TAN CH1 are from depths of $83,86,128$, and $176 \mathrm{~m}$.

At ISU the selected basalt samples were prepared for batch experiments by first removing the exterior surface rind. The rind was removed by placing the basalt core on the center of a precleaned circular steel plate and crushing with a pre-cleaned hammer. Fragments with exterior rind were removed from the sample. The samples were then packaged, labeled, and crushed and sieved through a $2.83-\mathrm{mm}$ sieve.

\section{Preparation of the Synthesized Aqueous Solution}

A synthesized aqueous solution that chemically represented wastewater in the ICPP infiltration ponds was prepared because of the difficulty in obtaining actual wastewater and because of the potential chemical changes associated with the long-term storage of wastewater. The synthesized aqueous solution contained dissolved calcium, chloride, magnesium, potassium, sodium, strontium, silica, and carbonate alkalinity. The $\mathrm{pH}$ of the synthesized aqueous solution was fixed at $8.0 \pm 0.1$. The use of a synthesized aqueous solution allowed for the control of experimental variables, and potential saturation problems and chemical-phase modifications, and provided a constant supply of solution.

A concentrated stock solution containing 1,000 $\mathrm{mg} / \mathrm{L}$ of calcium, $200 \mathrm{mg} / \mathrm{L}$ of magnesium, and $200 \mathrm{mg} / \mathrm{L}$ of potassium was prepared by adding American Chemical Society (ACS) certified reagents of calcium carbonate, magnesium carbonate, and potassium chloride along with concentrated trace-metal-grade hydrochloric acid to deionized water. A concentrated stock solution containing $1,000 \mathrm{mg} / \mathrm{L}$ of stable strontium was prepared separately by adding ACS-certified strontium carbonate and concentrated trace-metal-grade hydrochloric acid to deionized water. Stable strontium was substituted for the radioactive ${ }^{90} \mathrm{Sr}$ isotope so that no special handling was required. Stable strontium is assumed to behave geochemically in the same manner as ${ }^{90} \mathrm{Sr}$. Concentrated trace-metal-grade hydrochloric acid was added to the stock solutions to enhance stability of the concentrated solutions and to evolve carbon dioxide. The resulting $\mathrm{pH}$ of the concentrated stock solutions was less than 2.0 .

Four volumetric flasks of the synthesized aqueous solution were prepared by first diluting the concentrated stock solution of calcium, magnesium, and potassium with deionized water. The solution in each of the flasks then was spiked with different amounts of the strontium stock solution. 
Next, silica, in the form of sodium silicate, was added directly to the solutions using a Fisher Scientific $1,000-\mathrm{mg} / \mathrm{L}$ atomic-absorption reference standard. The $\mathrm{pH}$ then was adjusted to $8.0 \pm 0.1$ by adding 1.0-molar sodium hydroxide and hydrochloric acid. Sodium then was added to the synthesized aqueous solutions in the form of solid sodium bicarbonate and the $\mathrm{pH}$ was readjusted to 8.0. Finally, the solutions were equilibrated with atmospheric gases by leaving the flasks open to the atmosphere overnight and then adjusting the $\mathrm{pH}$ again, if necessary.

The synthesized aqueous solutions were prepared and spiked with strontium. Target concentrations of alkalinity, aluminum, calcium, iron, magnesium, potassium, silica, sodium, and strontium and $\mathrm{pH}$ are listed in table 4. Because the strontium concentrate used for spiking was acidified, each of the spiked solutions required different amounts of sodium hydroxide and hydrochloric acid for $\mathrm{pH}$ adjustment, which caused slight variations in the concentrations of sodium and chloride. These slight variations were not expected to affect strontium sorption to a measurable degree. Chloride concentrations were not determined analytically. Target concentrations of calcium, magnesium, potassium, silica, sodium, and $\mathrm{pH}$ of the synthesized aqueous solution were based on typical concentrations of these constituents in historical wastewater samples from ICPP disposal ponds (table 5). Historical pond-water analyses (table 5) presented as supporting data in this report were performed by the U.S. Geological Survey's National Water Quality Laboratory using analytical techniques prescribed by Skougstad and others (1979). Alkalinity concentrations were dependent on the amount of sodium bicarbonate added to the solution as described above.

\section{Experimental Methods}

The strontium $\mathrm{K}_{\mathrm{d}}$ studies were done using batch experimental techniques in $50-\mathrm{cm}^{3}$ polyethylene centrifuge tubes. Batch experiments were used because they are relatively simple and inexpensive, and many experiments can be done simultaneously. Basalt samples were homogenized and split into 2-g subsamples using a riffler to minimize bias. The 2-g subsamples were equilibrated with $20.0 \mathrm{~mL}$ of the synthesized aqueous solution at $30^{\circ} \mathrm{C}$ in a constant-temperature shaker at a setting of 70 cycles per minute for 144 hours. The 1 to-10 mass-to-volume ratio was selected so that the amount of sorption would be larger than the analytical uncertainty. Del Debbio and Thomas (1989) previously demonstrated that smaller ratios, such as 1 to 20 , resulted in significant measurement error. The time of equilibration and the agitation rate were selected to be consistent with $\mathrm{Del}$ Debbio and Thomas (1989). The time of equilibration also was demonstrated to be sufficient by kinetic experiments performed in this study that indicated that sorption was relatively rapid and nearly complete within 60 hours. The aqueous phase was separated from the solid phase at the end of the experiment by centrifugation for 12 minutes at 3,500 revolutions per minute. The supernatant samples were preserved by adding a small amount of trace-metal-grade concentrated nitric acid.

Linear sorption isotherms for each basalt sample were determined from strontium-distribution data for four initial-solution concentrations (table 4). Strontium linear sorption isotherms and $K_{d}$ 's were derived from the least-squares regression of equilibrium concentrations of strontium sorbed to the basalt as a function of dissolved strontium in solution (Fetter, 1993, p. 118). Concentrations of dissolved strontium were measured directly using inductively coupled plasma techniques. Concentrations of sorbed strontium were calculated as the difference between the initial and equilibrium concentrations of dissolved strontium multiplied by the volume-to-mass ratio. Initial concentrations were determined on the basis of concentrations in control samples measured at the conclusion of the experiment. Control samples consisted of reaction vessels containing the synthesized aqueous solution and no basalt. The determination of initialsolution concentrations assumed that any changes that occurred during the experiments in the solution concentrations of the control samples also occurred in the regular samples. To best represent field conditions in the unsaturated and perched ground-water zones, the basalt samples were not pretreated with the simulated-wastewater solution before experimentation. 
Experiments were grouped into sets consisting of 12 samples of basalt mixed with synthesized aqueous solution in centrifuge tubes, three replicate basalt subsamples at each of four strontium concentrations in the synthesized aqueous solution. Additionally, an experimental blank and four control samples were included in each experimental set. The blank consisted of a centrifuge tube containing only deionized water, and control samples consisted of centrifuge tubes containing only synthesized aqueous solution, one at each of the four strontium concentrations. Blanks and controls provided experimental evidence that the constituents in these experiments did not adsorb onto or desorb from the reaction-vessel walls or experimental apparatus.

The synthesized aqueous solutions, controls, and blanks were analyzed for concentrations of alkalinity, aluminum, iron, calcium, magnesium, potassium, sodium, strontium, $\mathrm{pH}$, and specific conductance before and after equilibration with the basalt. Cation concentrations were determined using a Perkin Elmer Plasma 400 Emission Spectrometer with Plasma 400 software, Color version 4.10 , using the standard methods for metals in water (Greenberg and others, 1992); $\mathrm{pH}$ was measured using an Orion Research model $231 \mathrm{pH}$ meter, specific conductivity was measured using a Fischer Scientific conductivity meter; and alkalinity was determined using a Hach digital titrator.

\section{Derivation of the Strontium Distribution Coefficient Using the Linear Sorption Isotherm Model}

The measured distribution coefficient is defined by Kipp and others (1986, p. 523) as:

$$
\mathrm{K}_{\mathrm{d}}=[\mathrm{Sr}]_{\mathrm{s}} /[\mathrm{Sr}]_{\mathrm{eq}}
$$

where

$\mathrm{K}_{\mathrm{d}}$ is measured in milliliters per gram,

$[\mathrm{Sr}]_{\mathrm{S}}=$ concentration of sorbed constituent per unit mass of basalt, in milligram per kilogram, and

$[\mathrm{Sr}]_{\mathrm{eq}}=$ concentration of dissolved constituent in the equilibrated solution, in milligram per liter.

Equilibrium sorption of solutes on basalt material commonly is described by the linear isotherm model, where the $\mathrm{K}_{\mathrm{d}}$ is equal to the slope of a least-squares fit between sorbed and aqueous strontium concentrations at thermodynamic equilibrium (Fetter, 1993, p. 118). Plots of isotherms for the basalt samples used in the study indicated. that the basalts conformed to the linear isotherm model. Therefore, the slopes of the linear sorption isotherms were used to calculate the $K_{d}$ 's in this study.

Experimental values of $[\mathrm{Sr}]_{\mathrm{s}}$ were determined using assayed concentrations of aqueous strontium and ratios of solution to basalt used in experimentation:

$$
[\mathrm{Sr}]_{\mathrm{s}}=\left\{[\mathrm{Sr}]_{\mathrm{i}}-[\mathrm{Sr}]_{\mathrm{eq}}\right\} \mathrm{V} / \mathrm{M}
$$

where

$[\mathrm{Sr}]_{\mathrm{i}}=$ initial concentration of aqueous strontium in the solution before equilibration with the

basalt, in milligrams per liter,

$\mathrm{V}=$ volume of solution, in milliliters, and

$\mathbf{M}=$ mass of basalt, in grams.

\section{STRONTIUM DISTRIBUTION COEFFICIENTS OF BASALT CORE SAMPLES}

The basalt sample mass, initial- and final-solution concentrations of aluminum, calcium, iron, magnesium, potassium, sodium, and strontium, the initial and final specific conductance and $\mathrm{pH}$ and measured strontium $\mathrm{K}_{d}$ 's of each basalt sample are presented in table 6 . The calculated strontium $\mathrm{K}_{d}$ 's of the 24 basalt samples ranged from $3.6 \pm 1.3$ to $29.4 \pm 1.6 \mathrm{~mL} / \mathrm{g}$ (table 7). The calculated $\mathrm{K}_{d}$ 's were determined from the slope of the linear isotherm model, and the uncertainties are the standard error of the linear regression. The measured strontium $\mathrm{K}_{\mathrm{d}}$ 's for three replicate determinations ranged from $-10.0 \pm 0.02 \mathrm{~mL} / \mathrm{g}$ for a sample with an initial strontium concentration of $0 \mathrm{mg} / \mathrm{L}$ to $27.0 \pm 1.1 \mathrm{~mL} / \mathrm{g}$ for a sample with an initial strontium concentration of $2.5 \mathrm{mg} / \mathrm{L}$ (table 7). The negative strontium $\mathrm{K}_{\mathrm{d}}$ 's for the initial strontium concentrations of $0 \mathrm{mg} / \mathrm{L}$ indicate that strontium was desorbing from the basalt samples at that concentration. The isotherm calculations incorporate uniformly the desorption effect for all experimental samples at each site. 
The results of the experiments show a narrow range of $\mathrm{K}_{\mathrm{d}}$ 's of basalt samples compared with the ranges of $\mathrm{K}_{d}$ 's of surficial and interbed sediments at the INEEL (Liszewski and others, 1997; Liszewski and others, 1998). The surficial sediment $K_{d}$ 's ranged from $26 \pm 1$ to $275 \pm 3 \mathrm{~mL} / \mathrm{g} ; \mathrm{K}_{\mathrm{d}}$ 's of interbed sediments ranged from $38 \pm 7$ to $328 \pm 41 \mathrm{~mL} / \mathrm{g}$. $\mathrm{K}_{d}$ 's of both types of sediments were determined using experimental methods similar to those used for the basalt samples. The results of the sediment experiments indicate that the ion-exchange mechanism was the predominant sorption mechanism. In contrast, the basalts had low strontium sorption and showed little evidence of exchangeable ions in the equilibrium solutions (table 6). Instead the predominant sorption mechanism probably was physisorption, which resulted in significantly smaller $\mathrm{K}_{\mathrm{d}}$ values, as shown in table 7 .

$\mathrm{K}_{d}$ 's of the basalt samples that contained exchangeable cations in small amounts of secondary minerals or sediment infill were among the smallest $\mathrm{K}_{\mathrm{d}}$ values. These samples contained elevated calcium concentrations in the equilibrium solutions owing to dissolution of the minerals and sediments. The solvated calcium cations effectively filled the sorption sites, sites that otherwise could have sorbed strontium, on the silicious basalt surface. This process resulted in the small $\mathrm{K}_{\mathrm{d}}$ values of the basalt samples.

Initial expectations of this study were that the vesicular basalts would produce larger $\mathrm{K}_{d}$ 's than the massive samples. This was expected because many of the vesicular samples had sedimentary infill material and secondary mineralization which was expected to increase the sorption capacity of the analyzed sample. Tables 1 and 7 show that the sorption values were similar for both the massive and vesicular samples. The $\mathrm{K}_{d}$ 's ranged from $4.1 \pm 0.95$ to $23.3 \pm 1.4 \mathrm{~mL} / \mathrm{g}$ for the massive samples and from $3.6 \pm 1.3$ to $29.4 \pm 1.6 \mathrm{~mL} / \mathrm{g}$ for the vesicular samples. This similarity in $\mathrm{K}_{\mathrm{d}}$ ranges may indicate that the results of sample preparation affected $\mathrm{K}_{d}$ 's more than the physical nature of the samples before preparation. During sample preparation, significant amounts of fresh surfaces were generated for both massive and vesicular samples. This may have decreased the effect of the texture of the samples on the $\mathrm{K}_{d}$ 's. This theory is sup- ported by the BET surface-area analyses (table 3 ), which indicated a very narrow range of surfacearea values for the samples analyzed.

\section{CONCLUSIONS}

The results indicate that the basalt samples have small strontium $\mathrm{K}_{d}$ 's and a narrow range of $\mathrm{K}_{d}$ 's. There was no correlation between $\mathrm{K}_{d}$ 's of the basalt samples and any of the following characteristics: presence of secondary mineralization or sediment infill, sample texture (massive or vesicular), sample depth, aerial position, or sample composition. The narrow range of $\mathrm{K}_{d}$ 's can be attributed to the physical and chemical properties of the basalt samples and to compositional changes in the equilibrated solutions after being mixed with the basalt. The small $\mathrm{K}_{d}$ 's indicate that there is probably only a small amount of sorption of strontium on basalts in the Snake River Plain aquifer system, therefore, basalt probably does not impede the movement of strontium-90 in solution.

\section{REFERENCES CITED}

Ames, L.L., and Rai, D., 1978, Radionuclide interactions with soil and rock media, v. 1 of processes influencing radionuclide mobility and retention, element chemistry and geochemistry, conclusions and evaluation: U.S. Environmental Protection Agency, EPA 520/6-78007, variously paged.

Anderson, S.R., 1991, Stratigraphy of the unsaturated zone and uppermost part of the Snake River Plain aquifer at the Idaho Chemical Processing Plant and Test Reactors Area, Idaho National Engineering Laboratory, Idaho: U.S. Geological Survey Water-Resources Investigations Report 91-4010, 71 p.

Anderson, S.R., and Bowers, B., 1995, Stratigraphy of the unsaturated zone and uppermost part of the Snake River Plain at the Test Area North, Idaho National Engineering Laboratory, Idaho: U.S. Geological Survey WaterResources Investigations Report 95-4130, $47 \mathrm{p}$. 
Barney, G.S., 1981, Radionuclide reactions with groundwater and basalts from Columbia River Basalts: Rockwell Hanford Operations, prepared for U.S. Department of Energy, RHOSA-217, [52] p.

Bartholomay, R.C., 1998, Distribution of selected radiochemical and chemical constituents in perched ground water, Idaho National Engineering Laboratory, Idaho, 1992-95: WaterResources Investigations Report 98-4026, $59 \mathrm{p}$.

Bartholomay, R.C., Orr, B.R., Liszewski, M.J., and Jensen, R.G., 1995, Hydrologic conditions and distribution of selected chemical constituents in water, Snake River Plain aquifer, Idaho National Engineering Laboratory, Idaho, 1989 through 1991: U.S. Geological Survey Water-Resources Investigations Report 95-4175, 47 p.

Bartholomay, R.C., Tucker, B.J., Ackerman, D.J., and Liszewski, M.J., 1997, Hydrologic conditions and distribution of selected radiochemical and chemical constituents in water, Snake River Plain aquifer, Idaho National Engineering Laboratory, Idaho, 1992 through 1995: U.S. Geological Survey Water-Resources Investigations Report 97-4086, 57 p.

Bohn, H.L., 1985, Soil chemistry: New York, John Wiley and Sons, Inc., 341 p.

Brunauer, S., Emmett, P.H., and Teller, E., 1938, Adsorption of gases in multimolecular layers: Journal of American Chemical Society, v. 60, p. 309-319.

Bunde, R.L., Rosentreter, J.J., and Liszewski, M.J., 1998, Rate of strontium sorption and the effects of variable aqueous concentrations of sodium and potassium on strontium distribution coefficients of a surficial sediment at the Idaho National Engineering Laboratory, Idaho: Environmental Geology, v. 34, no. 2-3, p. 135-142.

Bunde, R.L., Rosentreter, J.J., Liszewski, M.J., Hemming, C.H., and Welhan, J., 1997 , Effects of calcium and magnesium on strontium distribution coefficients: Environmental Geology, v. 32(3), p. 219-229.
Davis, L.C., Hannula, S.R., and Bowers, Beverly, 1997, Procedures for use of, and drill cores and cuttings available for study at, the lithologic core storage library, Idaho National Engineering Laboratory, U.S. Geological Survey Open-File Report 97-124, 31 p.

Del Debbio, J.A., and Thomas, T.R., 1989, Transport properties of radionuclides and hazardous chemical species in soils at the Idaho Chemical Processing Plant: Idaho Falls, Idaho, Westinghouse Idaho Nuclear Company, Inc., WINCO-1068, variously paged.

Eisenbud, M., 1973, Environmental radioactivity: New York and London, Academic Press, $542 \mathrm{p}$.

Fetter, C.W., 1993, Contaminant hydrogeology: New York, Macmillan International, $458 \mathrm{p}$.

Greenberg, A.E.; Clesceri, L.S., and Eaton, A.D.; eds., 1992, Standard methods for the examination of water and wastewater (18th ed.): American Public Health Association, American Water Works Association, Water Environment Federation, variously paged.

Hawkins, D.B., and Short, H.L., 1965, Equations for the sorption of cesium and strontium on soil and clinoptilolite: U.S. Atomic Energy Commission, Idaho Operations Office, IDO$12046,33 \mathrm{p}$.

Hemming, C.H., Bunde, R.L., Liszewski, M.J., Rosentreter, J.J., and Welhan, J., 1997, Effect of experimental techniques on the determination of strontium distribution coefficients of a surficial sediment from the Idaho National Engineering Laboratory, Idaho: Water Research, v. 31, no. 7, p. 1629-1636.

Kipp, K.L., Stollenwerk, K.G., and Grove, D.B., 1986, Groundwater transport of strontium-90 in a glacial outwash environment: Water Resources Research, v. 22, p. 519-530.

Lanphere, M.A., Champion, D.E., and Kuntz, M.A., 1993, Petrography, age, and paleomagnetism of basalt flows in coreholes well 80 , NRF-89-04, NRF-89-05, and ICPP 123, Idaho 
National Engineering Laboratory: U.S. Geological Survey Open-File Report 93-327, $40 \mathrm{p}$.

Lanphere, M.A., Kuntz, M.A., and Champion, D.E., 1994, Petrography, age, and paleomagnetism of basaltic lava flows in coreholes at Test Area North (TAN), Idaho National Engineering Laboratory: U.S. Geological Survey Open-File Report 94-686, 49 p.

Liszewski, M.J., Rosentreter, J.J., and Miller, K.E., 1997, Strontium distribution coefficients of surficial sediment samples from the Idaho National Engineering Laboratory, Idaho: Water-Resources Investigations Report 974044, 33 p.

Liszewski, M.J., Rosentreter, J.J., Miller, K.E., and Bartholomay, R.C., 1998, Strontium distribution coefficients of surficial and sedimentary interbed samples from the Idaho National Engineering and Environmental Laboratory, Idaho: Water-Resources Investigations Report 98-4073, $55 \mathrm{p}$.

Mundorff, M.J., Crosthwaite, E.G., and Kilburn, C., 1964, Ground water for irrigation in the Snake River Basin in Idaho: U.S. Geological Survey Water-Supply Paper 1654, 224 p.

Newman, M.E., Porro, I., Scott, R., Dunnivant, F.M., Goff, R.W., Blevins, M.D., Ince, S.M., Leyba, J.D., DeVol, T.A., Elzerman, A.W., and Fjeld, R.A., 1996, Evaluation of the mobility of $\mathrm{Am}, \mathrm{Cs}, \mathrm{Co}, \mathrm{Pu}, \mathrm{Sr}$, and $\mathrm{U}$ through
INEL basalt and interbed materials: Summary Report of the INEL/Clemson University Laboratory Studies: Wag7-82, INEL-95/282, variously paged.

Pittman, J.R., Jensen, R.G., and Fischer, P.R., 1988 , Hydrologic conditions at the Idaho National Engineering Laboratory, 1982 to 1985: U.S. Geological Survey WaterResources Investigations Report 89-4008, $73 \mathrm{p}$.

Robertson, J.B., Schoen, R., and Barraclough, J.T., 1974, The influence of liquid waste disposal on the geochemistry of water at the National Reactor Testing Station, Idaho, 1952-1970: U.S. Geological Survey Open-File Report, IDO-22053, $231 \mathrm{p}$.

Schmalz, B.L., 1972, Radionuclide distribution in soil mantle of the lithosphere as a consequence of waste disposal at the National Reactor Testing Station: U.S. Atomic Energy Commission, Idaho Operations Office, IDO$10049,80 \mathrm{p}$.

Skougstad, M.W., Fishman, M.J., Friedman, L.C., Erdmann, D.E., and Duncan, S.S., eds., 1979, Methods for analysis of inorganic substances in water and fluvial sediment: U.S. Geological Survey Techniques of Water-Resources Investigations, book 5, chap. A1, $626 \mathrm{p}$.

Sposito, G., 1989, The chemistry of soils: New York, Oxford University Press, 277 p. 
Table 1. Depths and descriptions of basalt core samples from the Idaho National Engineering and Environmental Laboratory

[Depth is the approximate depth below land surface at which the sample was collected. Abbreviation: $m$, meter]

\begin{tabular}{ccc}
\hline Core site & Depth $(\mathbf{m})$ & Description \\
\hline 123 & 14 & $\begin{array}{l}\text { Samples are from top of flow, diktytaxitic, medium light gray. 14a highly vesicular; } 14 \mathrm{~b} \\
\text { massive but contains minor vesicles. Samples contain secondary mineralization, hematite } \\
\text { weathering and red oxidized surfaces. Yellow to orange alteration along the bottom of } \\
\text { sample 14b. }\end{array}$
\end{tabular}

WO-1

WO-1

WO-2

Wo-2

WO-2

WO-2

wo-2

TAN CH1

TAN CH1

TAN CH1

TAN CH1
Sample is from top of flow, highly vesicular, diktytaxitic, reddish dark gray and contains sediment along fracture and minor calcite/caliche rinds in vesicles.

Sample is from middle of flow, diktytaxitic, reddish dark gray and contains calcite deposition in rounded vesicles. Vertical fracture is present with caliche deposition and some weathering alteration.

Sample is from the top of the flow, slightly diktytaxitic, medium dark gray, and contains minor calcite precipitation in rounded vesicles.

Sample is from top of flow, diktytaxitic, reddish brown, and contains elongate vesicles filled with sediment near top of sample. Minor sediment infill further down sample. Also contains glomerophyric plagioclase phenocrysts and iron oxide deposits associated with olivines.

Sample is from top of the flow, diktytaxitic, medium dark gray, and contains round to elongate vesicles with minor calcite precipitation.

Sample is from top of flow, reddish brown, highly vesicular and contains round to elongate vesicles with many precipitated globs of calcite.

Sample is from middle of flow, reddish gray, massive, and contains tiny spherical vesicles. Iron oxide stain on plagioclase phenocrysts.

Sample is from bottom of flow, medium gray, massive and contains minor round to elongated vesicles.

Sample is from bottom of flow from a fracture zone, slightly diktytaxitic, reddish brown, and vesicular. Caliche rinds in some vesicles and calcite coating on fracture surfaces.

Sample is reddish brown, slightly diktytaxitic, fractured vesicular. Fracture surface is coated with fine purplish precipitate.

Sample is light gray, slightly diktytaxitic, massive and contains small round vesicles.

Sample is reddish gray, slightly diktytaxitic and contains minor round vesicles with light coating of white to blue precipitate.

Sample is medium gray, slightly diktytaxitic, vesicular and contains minor sediment infill in vesicles.

Sample is massive, gray, diktytaxitic and contains minor vesicles with no infill.

Sample is massive, gray, diktytaxitic and contains minor round vesicles and no infill.

Sample is highly vesicular, dark gray and contains minor sediment infill.

Sample is massive, gray, slightly diktytaxitic and contains minor spherical vesicles and no infill. Sample has many large plagioclase laths and weathered olivines.

Sample is massive, light gray, diktytaxitic and contains minor small vesicles.

Sample is dark gray, diktytaxitic, vesicular and contains some minor sediment infill.

Sample is massive, dark gray, diktytaxitic and contains little vesicularity.

Sample is massive, brownish gray, fractured. Fractures are covered with white bluish precipitate. 
Table 2. Whole-rock analysis for selected major, minor, and trace elements of basalt samples from the Idaho National Engineering and Environmental Laboratory

[Silica, titanium, aluminum, iron, manganese, magnesium, calcium, sodium, and potassium are reported as oxide concentrations in weight percent. Strontium and barium are reported as elcmental concentrations in parts per million. Whole-rock analysis determined using inductively coupled plasma techniques. $\mathrm{Abbreviations:} \mathrm{SiO}_{2}$, silica dioxide; $\mathrm{TiO}_{2}$, titanium dioxide; $\mathrm{Al}_{2} \mathrm{O}_{3}$, aluminum oxide; $\mathrm{Fe}_{2} \mathrm{O}_{3}$, iron oxide; $\mathrm{MnO}$, manganese oxide; $\mathrm{MgO}$, magnesium oxide; $\mathrm{CaO}$, calcium oxide; $\mathrm{Na} 2 \mathrm{O}$, sodium oxide; $\mathrm{K}_{2} \mathrm{O}$, potassium oxide; Sr, strontium; $\mathrm{Ba}$, barium]

\begin{tabular}{|c|c|c|c|c|c|c|c|c|c|c|c|}
\hline \multirow[b]{2}{*}{ Sample name } & \multicolumn{9}{|c|}{ Whole rock analysis } & \multicolumn{2}{|c|}{ ppm } \\
\hline & $\mathrm{SiO}_{2}$ & $\mathrm{TiO}_{2}$ & $\mathrm{Al}_{2} \mathrm{O}_{3}$ & $\mathrm{Fe}_{2} \mathrm{O}_{3}$ & $\mathrm{MnO}$ & $\mathrm{MgO}$ & $\mathrm{CaO}$ & $\mathrm{Na}_{2} \mathrm{O}$ & $\mathrm{K}_{2} \mathrm{O}$ & $\mathbf{S r}$ & $\mathbf{B a}$ \\
\hline $123-14 a$ & 46.2 & 3.78 & 12.4 & 16.7 & 0.22 & 5.16 & 9.83 & 2.75 & 0.89 & 268 & 497 \\
\hline $123-14 b$ & 45.9 & 2.60 & 14.3 & 15.4 & .20 & 8.25 & 9.60 & 2.55 & .57 & 283 & 326 \\
\hline $123-64$ & 45.7 & 2.95 & 14.3 & 15.7 & .20 & 6.92 & 9.30 & 2.51 & .85 & 308 & 501 \\
\hline $123-68$ & 46.2 & 3.24 & 14.6 & 15.9 & .20 & 6.58 & 9.50 & 2.52 & .89 & 311 & 507 \\
\hline $123-130$ & 47.9 & 1.76 & 15.2 & 12.4 & .18 & 8.50 & 10.3 & 2.25 & .62 & 247 & 297 \\
\hline $123-153$ & 46.3 & 1.35 & 14.8 & 11.7 & .17 & 10.5 & 10.0 & 2.11 & .35 & 196 & 193 \\
\hline $123-156$ & 47.6 & 1.67 & 15.2 & 12.7 & .18 & 10.3 & 10.0 & 2.31 & .56 & 229 & 270 \\
\hline $123-172$ & 46.5 & 2.72 & 14.7 & 15.0 & .20 & 6.94 & 10.9 & 2.50 & .67 & 293 & 411 \\
\hline $123-189$ & 47.7 & 2.25 & 15.2 & 14.4 & .19 & 9.02 & 10.3 & 2.45 & .54 & 264 & 288 \\
\hline 123-209 & 47.8 & 2.20 & 15.4 & 14.4 & .19 & 9.46 & 10.5 & 2.41 & .46 & 266 & 266 \\
\hline $123-211 \mathrm{a}$ & 46.7 & 2.21 & 15.0 & 13.9 & .19 & 8.65 & 9.97 & 2.34 & .74 & 270 & 376 \\
\hline $123-211 \mathrm{~b}$ & 46.9 & 2.25 & 14.9 & 14.0 & .19 & 8.70 & 10.4 & 2.35 & .69 & 269 & 383 \\
\hline $123-221$ & 45.4 & 3.06 & 14.2 & 16.2 & .21 & 6.95 & 9.39 & 2.51 & .79 & 315 & 479 \\
\hline W0-1-141 & 46.8 & 3.01 & 14.5 & 16.0 & .21 & 7.40 & 9.84 & 2.47 & .62 & 352 & 460 \\
\hline W0-1-146 & 46.6 & 2.75 & 14.7 & 15.4 & .20 & 7.56 & 9.57 & 2.48 & .69 & 344 & 440 \\
\hline W0-2-185 & 46.5 & 2.26 & 14.9 & 14.2 & .19 & 8.96 & 10.3 & 2.36 & .49 & 259 & 290 \\
\hline W0-2-186 & 47.5 & 2.21 & 15.3 & 14.4 & .19 & 9.39 & 10.5 & 2.38 & .48 & 264 & 276 \\
\hline W0-2-397 & 48.0 & 2.42 & 15.0 & 14.3 & .19 & 8.13 & 10.2 & 2.53 & .67 & 305 & 336 \\
\hline W0-2-400 & 47.8 & 2.13 & 15.1 & 14.2 & .19 & 9.03 & 10.3 & 2.38 & .55 & 257 & 357 \\
\hline W0-2-520 & 46.2 & 3.23 & 13.8 & 16.9 & .23 & 8.04 & 9.58 & 2.39 & .60 & 286 & 394 \\
\hline TAN CH1-83 & 46.9 & 2.54 & 14.6 & 15.1 & .20 & 8.22 & 9.51 & 2.53 & .53 & 326 & 353 \\
\hline TAN CH1-86 & 45.2 & 2.58 & 14.7 & 15.3 & .20 & 7.36 & 9.40 & 2.48 & .42 & 332 & 451 \\
\hline TAN CH1-128 & 46.1 & 2.27 & 14.9 & 14.6 & .19 & 7.77 & 10.40 & 2.45 & .37 & 271 & 302 \\
\hline TAN CH1-176 & 45.5 & 2.88 & 14.7 & 16.1 & .20 & 7.39 & 9.56 & 2.71 & .46 & 323 & 328 \\
\hline
\end{tabular}


Table 3. Brunauer-Emmett-Teller surface areas of selected basalt samples from the Idaho National Engineering and Environmental Laboratory

[The surface area of each basalt sample was determined using the Brunauer-Emmett-Teller (BET) method (Brunauer and others, 1938). BET surface area was determined using a Micromeritics Gemini 2360 surface-area analyzer. Abbreviation: $\mathrm{m}^{2} / \mathrm{g}$, meters squared per gram]

\begin{tabular}{lc}
\hline Sample name & Surface area $\left(\mathbf{m}^{2} / \mathbf{g}\right)$ \\
\hline $123-153$ & 0.33 \\
$123-156$ & .96 \\
$123-172$ & 1.2 \\
$123-189$ & 1.4 \\
& \\
$123-209$ & 1.5 \\
$123-211$ & 1.4 \\
$123-221$ & 1.9 \\
& \\
WO-1-141 & 2.5 \\
& \\
WO-1-146 & 1.3 \\
WO-2-185 & .99 \\
WO-2-186 & 1.8 \\
WO-2-400 & 1.1 \\
\hline
\end{tabular}


Table 4. Target concentrations of alkalinity, aluminum, calcium, iron, magnesium, potassium, silica, sodium, strontium, and pH in the synthesized aqueous solutions used in the strontium batch experiments

[Alkalinity was determined using a Hach digital titrator. Aluminum, calcium, iron, magnesium, potassium, silica, sodium, and strontium concentrations were determined by assay using inductively coupled plasma. $\mathrm{pH}$ was measured using an Orion Research model $231 \mathrm{pH}$ meter. Sodium concentrations include sodium additions from sodium bicarbonate, sodium hydroxide, and sodium silicate. Abbreviations: $\mathrm{mg} / \mathrm{L}$, milligrams per liter; $\mathrm{CaCO}_{3}$, calcium carbonate; $\mathrm{SiO}_{2}$, silica dioxide]

\begin{tabular}{|c|c|c|c|c|c|c|c|c|c|}
\hline $\begin{array}{l}\text { Alkalinity } \\
(\mathrm{mg} / \mathrm{L} \text { as } \\
\left.\mathrm{CaCO}_{3}\right)\end{array}$ & $\begin{array}{l}\text { Aluminum } \\
\text { (mg/L) }\end{array}$ & $\begin{array}{l}\text { Calcium } \\
(\mathrm{mg} / \mathrm{L})\end{array}$ & $\begin{array}{c}\text { Iron } \\
(\mathbf{m g} / \mathbf{L})\end{array}$ & $\begin{array}{l}\text { Magnesium } \\
(\mathrm{mg} / \mathrm{L})\end{array}$ & $\begin{array}{l}\text { Potassium } \\
\text { (mg/L) }\end{array}$ & $\begin{array}{c}\text { Silica } \\
\left(\mathrm{mg}^{\prime} / \mathrm{L} \text { as }\right. \\
\left.\mathrm{SiO}_{2}\right)\end{array}$ & $\begin{array}{l}\text { Sodium } \\
(\mathrm{mg} / \mathbf{L})\end{array}$ & $\begin{array}{c}\text { Strontium } \\
\text { (mg/L) }\end{array}$ & pH \\
\hline 99 & 0 & 10 & 0 & 2 & 2 & 21 & 79.0 & 0 & 8.0 \\
\hline 100 & 0 & 10 & 0 & 2 & 2 & 21 & 78.8 & 2.5 & 8.0 \\
\hline 96 & 0 & 10 & 0 & 2 & 2 & 21 & 78.7 & 5.0 & 8.0 \\
\hline
\end{tabular}

Table 5. Concentrations of alkalinity, calcium, magnesium, potassium, silica, sodium, and strontium, and $\mathrm{pH}$ in samples collected from infiltration ponds at the Idaho Chemical Processing Plant

[Analyses were performed by the U.S. Geological Survey's National Water Quality Laboratory using analytical techniques prescribed by Skougstad and others (1979). Abbreviations: $\mathrm{mg} / \mathrm{L}$, milligrams per liter; $\mathrm{CaCO}_{3}$, calcium carbonate; $\mathrm{SiO}_{2}$, silica dioxide. Location of ponds shown on fig. 2]

\begin{tabular}{|c|c|c|c|c|c|c|c|c|}
\hline $\begin{array}{l}\text { Date } \\
\text { sampled }\end{array}$ & $\begin{array}{l}\text { Alkalinity } \\
(\mathrm{mg} / \mathrm{L} \text { as } \\
\left.\mathrm{CaCO}_{3}\right)\end{array}$ & $\begin{array}{l}\text { Calcium } \\
(\mathrm{mg} / \mathrm{L})\end{array}$ & $\begin{array}{l}\text { Magnesium } \\
\quad(\mathrm{mg} / \mathrm{L})\end{array}$ & $\begin{array}{l}\text { Potassium } \\
(\mathrm{mg} / \mathrm{L})\end{array}$ & $\begin{array}{c}\text { Silica } \\
\left(\mathrm{mg} / \mathrm{L} \text { as } \mathrm{SiO}_{2}\right) \\
\end{array}$ & $\begin{array}{c}\text { Sodium } \\
(\mathrm{mg} / \mathrm{L})\end{array}$ & $\begin{array}{c}\text { Strontium } \\
(\mathrm{mg} / \mathrm{L})\end{array}$ & pH \\
\hline $10 / 27 / 86$ & 158 & 3.7 & 1.2 & 1.2 & 21 & 87 & 0.017 & 8.30 \\
\hline $1 / 28 / 87$ & 159 & 5.7 & 1.4 & 2.5 & 21 & 84 & .029 & 8.29 \\
\hline $10 / 26 / 87$ & 150 & 9.7 & 2.5 & 1.6 & 21 & 88 & .051 & 8.50 \\
\hline $1 / 25 / 88$ & 125 & 2.5 & .65 & .90 & 24 & 87 & .012 & 8.00 \\
\hline $4 / 26 / 88$ & 103 & 67 & 29 & 2.8 & 21 & 92 & .34 & 7.20 \\
\hline $7 / 28 / 88$ & 137 & 260 & 53 & 1.5 & 24 & 340 & 1.3 & 8.00 \\
\hline $10 / 31 / 88$ & 145 & 11 & 3.0 & 1.1 & 22 & 98 & .057 & 8.00 \\
\hline
\end{tabular}


Table 6. Basalt mass; initial and final aluminum, calcium, iron, magnesium, potassium, sodium, and strontium concentrations; initial and final conductivity and $\mathrm{pH}$; and measured distribution coefficients of synthesized solutions

[Sample set refers to all the samples associated with the determination of a single distribution coefficient. Sample numbers 1-3, 5-7, 9-11, and 13-15 represent triplicate experiments at each of 4 strontium concentrations. Sample type 1 refers to regular samples containing basalt and synthesized aqueous solution; type 2 refers to control samples containing only synthesized aqueous solution without basalt, and type 3 (number 17) refers to a blank sample containing only deionized water. Basalt mass is the mass of basalt mixed with 20.0 milliliters of synthesized aqueous solution. Initial concentrations for sample numbers $4,8,12$, and 16 (control samples) are those determined for the synthesized aqueous solution before the experiments began. Initial concentrations for aluminum (Al), calcium $(\mathrm{Ca})$, iron $(\mathrm{Fe})$, magnesium $(\mathrm{Mg})$, potassium $(\mathrm{K})$, sodium $(\mathrm{Na})$ and strontium $(\mathrm{Sr})$ for sample numbers $1-3$, 5-7, 9-11, and 13-15 (regular samples) were determined on the basis of the final concentration of the control samples measured after the conclusion of the experiments. These determinations for the regular samples assume that any changes in solution concentrations that occurred in the control samples during the experiments also occurred in the regular samples. Final concentrations are of dissolved constituents after being equilibrated with the basalt for a period of 144 hours. Aluminum, calcium, iron, magnesium, potassium, sodium, and strontium concentrations were determined by assay using atomic-emission spectroscopy. Abbreviations: $\mu \mathrm{S} / \mathrm{cm}$, microseimens per centimeter; $\mathrm{mg} / \mathrm{L}, \mathrm{milligrams}$ per liter; $\Delta$, change; Kd, distribution coefficient]

\begin{tabular}{|c|c|c|c|c|c|c|c|c|c|c|c|}
\hline $\begin{array}{c}\text { Sample } \\
\text { set }\end{array}$ & $\begin{array}{l}\text { Sample } \\
\text { number }\end{array}$ & $\begin{array}{l}\text { Sample } \\
\text { type }\end{array}$ & $\begin{array}{c}\text { Basalt } \\
\text { mass } \\
\text { (grams) }\end{array}$ & Initial pH & Final pH & $\begin{array}{c}\text { Initial } \\
\text { conductivity } \\
(\mu \mathrm{S} / \mathrm{cm})\end{array}$ & $\begin{array}{c}\text { Final } \\
\text { conductivity } \\
(\mu \mathbf{S} / \mathbf{c m})\end{array}$ & $\begin{array}{c}\text { Initial Al } \\
(\mathrm{mg} / \mathrm{L})\end{array}$ & $\begin{array}{c}\text { Final Al } \\
(\mathbf{m g} / \mathbf{L})\end{array}$ & $\begin{array}{c}\text { Initial Ca } \\
\text { (mg/L) }\end{array}$ & $\begin{array}{c}\text { Final Ca } \\
(\mathrm{mg} / \mathrm{L})\end{array}$ \\
\hline $123-14 a$ & 1 & 1 & 1.9941 & 8.24 & 8.16 & 851 & 567 & 0.03 & 0.88 & 10.47 & 11.91 \\
\hline $123-14 a$ & 2 & 1 & 2.0018 & 8.24 & 8.22 & 851 & 572 & .03 & 1.25 & 10.47 & 11.82 \\
\hline $123-14 a$ & 3 & 1 & 2.0032 & 8.24 & 8.13 & 851 & 588 & .03 & 1.36 & 10.47 & 12.12 \\
\hline $123-14 a$ & 5 & 1 & 2.0032 & 8.24 & 8.21 & 681 & 552 & .03 & .46 & 10.87 & 11.55 \\
\hline $123-14 a$ & 6 & 1 & 1.9996 & 8.24 & 8.12 & 681 & 626 & .03 & 1.30 & 10.87 & 12.27 \\
\hline $123-14 a$ & 7 & 1 & 1.9954 & 8.24 & 8.23 & 681 & 745 & .03 & 1.98 & 10.87 & 13.87 \\
\hline $123-14 a$ & 9 & 1 & 2.0000 & 8.03 & 8.17 & 665 & 677 & .03 & 1.39 & 10.58 & 13.35 \\
\hline $123-14 a$ & 10 & 1 & 2.0036 & 8.03 & 8.21 & 665 & 667 & .03 & 1.27 & 10.58 & 12.83 \\
\hline $123-14 a$ & 11 & 1 & 2.0024 & 8.03 & 8.32 & 665 & 660 & .03 & .79 & 10.58 & 12.28 \\
\hline $123-14 a$ & 13 & 1 & 1.9990 & 8.27 & 8.21 & 502 & 388 & .05 & .91 & 11.27 & 13.50 \\
\hline $123-14 a$ & 14 & 1 & 2.0006 & 8.27 & 8.18 & 502 & 630 & .05 & .79 & 11.27 & 13.19 \\
\hline $123-14 a$ & 15 & 1 & 1.9986 & 8.27 & 8.22 & 502 & 424 & .05 & .79 & 11.27 & 13.19 \\
\hline $123-14 a$ & 4 & 2 & & 8.03 & 8.24 & 472 & 851 & .04 & .03 & 10.20 & 10.47 \\
\hline $123-14 a$ & 8 & 2 & & 8.06 & 8.24 & 452 & 681 & .05 & .03 & 9.68 & 10.87 \\
\hline $123-14 a$ & 12 & 2 & & 8.03 & 8.03 & 533 & 665 & .05 & .03 & 10.19 & 10.58 \\
\hline $123-14 a$ & 16 & 2 & & 8.00 & 8.27 & 563 & 502 & .04 & .05 & 10.45 & 11.27 \\
\hline $123-14 a$ & 17 & 3 & & 5.74 & 7.64 & 45 & 2 & .00 & .01 & .01 & .15 \\
\hline
\end{tabular}


Table 6. Basalt mass; initial and final aluminum, calcium, iron, magnesium, potassium, sodium, and strontium concentrations; initial and final specific conductance and $\mathrm{pH}$; and measured distribution coefficients of synthesized solutions - Continued

\begin{tabular}{|c|c|c|c|c|c|c|c|c|c|c|c|c|c|c|}
\hline $\begin{array}{c}\text { Sample } \\
\text { set }\end{array}$ & $\begin{array}{l}\text { Sample } \\
\text { number }\end{array}$ & $\begin{array}{c}\text { Sample } \\
\text { type }\end{array}$ & $\begin{array}{c}\text { Initial } \\
\text { Fe } \\
\text { (mg/L) }\end{array}$ & $\begin{array}{c}\text { Final Fe } \\
(\mathrm{mg} / \mathrm{L})\end{array}$ & $\begin{array}{c}\text { Initial } \\
\mathrm{Mg} \\
(\mathrm{mg} / \mathrm{L})\end{array}$ & $\begin{array}{c}\text { Final } \\
\mathrm{Mg} \\
(\mathrm{mg} / \mathrm{L})\end{array}$ & $\begin{array}{c}\text { Initial K } \\
\text { (mg/L) }\end{array}$ & $\begin{array}{c}\text { Final K } \\
(\mathrm{mg} / \mathrm{L})\end{array}$ & $\begin{array}{c}\text { Initial } \\
\mathrm{Na} \\
(\mathrm{mg} / \mathrm{L})\end{array}$ & $\begin{array}{c}\text { Final } \\
\mathrm{Na} \\
(\mathrm{mg} / \mathrm{L})\end{array}$ & $\begin{array}{c}\text { Initial } \\
\text { Sr } \\
(\mathrm{mg} / \mathrm{L})\end{array}$ & $\begin{array}{c}\text { Final Sr } \\
(\mathrm{mg} / \mathrm{L})\end{array}$ & $\Delta \mathbf{S r}$ & Sr Kd \\
\hline $123-14 a$ & 1 & 1 & 0.02 & 0.98 & 1.85 & 2.28 & 3.08 & 3.71 & 105.8 & 104.8 & 0.00 & 0.05 & -0.05 & -9.81 \\
\hline $123-14 a$ & 2 & 1 & .02 & 1.47 & 1.85 & 2.26 & 3.08 & 3.68 & 105.8 & 103.1 & .00 & .06 & -.06 & -9.79 \\
\hline $123-14 a$ & 3 & 1 & .02 & 1.67 & 1.85 & 2.39 & 3.08 & 3.65 & 105.8 & 104.3 & .00 & .06 & -.05 & -9.77 \\
\hline $123-14 a$ & 5 & 1 & .01 & .44 & 1.80 & 2.26 & 2.38 & 3.04 & 101.7 & 103.5 & 1.04 & .41 & .63 & 15.51 \\
\hline $123-14 a$ & 6 & 1 & $: 01$ & 1.55 & 1.80 & 2.32 & 2.38 & 3.11 & 101.7 & 97.9 & 1.04 & .41 & .64 & 15.72 \\
\hline $123-14 a$ & 7 & 1 & .01 & 5.08 & 1.80 & 3.95 & 2.38 & 3.20 & 101.7 & 97.9 & 1.04 & .42 & .62 & 14.75 \\
\hline $123-14 a$ & 9 & 1 & .00 & 2.96 & 1.78 & 2.68 & 2.53 & 3.28 & 97.2 & 98.7 & 2.56 & 1.06 & 1.50 & 14.07 \\
\hline $123-14 a$ & 10 & 1 & .00 & 1.99 & 1.78 & 2.53 & 2.53 & 3.19 & 97.2 & 99.7 & 2.56 & 1.01 & 1.55 & 15.24 \\
\hline $123-14 a$ & 11 & 1 & .00 & .87 & 1.78 & 2.24 & 2.53 & 3.17 & 97.2 & 96.2 & 2.56 & .97 & 1.58 & 16.25 \\
\hline $123-14 a$ & 13 & 1 & -.01 & 1.19 & 1.88 & 2.69 & 2.41 & 3.15 & 103.5 & 105.6 & 5.22 & 2.27 & 2.94 & $12.9 \dot{5}$ \\
\hline $123-14 a$ & 14 & 1 & -.01 & .95 & 1.88 & 2.56 & 2.41 & 3.13 & 103.5 & 104.7 & 5.22 & 2.28 & 2.94 & 12.87 \\
\hline $123-14 a$ & 15 & 1 & -.01 & .96 & 1.88 & 2.56 & 2.41 & 3.15 & 103.5 & 102.2 & 5.22 & 2.23 & 2.99 & $13 . \dot{41}$ \\
\hline $123-14 a$ & 4 & 2 & .01 & .02 & 1.86 & 1.85 & 3.02 & 3.08 & 105.2 & 105.8 & .00 & .00 & .00 & \\
\hline $123-14 a$ & 8 & 2 & .01 & .01 & 1.69 & 1.80 & 2.35 & 2.38 & 92.0 & 101.7 & .92 & 1.04 & -.12 & \\
\hline $123-14 a$ & 12 & 2 & .01 & .00 & 1.84 & 1.78 & 2.44 & 2.53 & 99.5 & 97.2 & 2.50 & 2.56 & -.05 & \\
\hline $123-14 a$ & 16 & 2 & .01 & -.01 & 1.75 & 1.88 & 2.34 & 2.41 & 99.9 & 103.5 & 5.01 & 5.22 & -.21 & \\
\hline $123-14 a$ & 17 & 3 & -.01 & .00 & .00 & .00 & .12 & .17 & -.8 & .4 & .00 & .00 & .00 & \\
\hline
\end{tabular}


Table 6. Basalt mass; initial and final aluminum, calcium, iron, magnesium, potassium, sodium, and strontium concentrations; initial and final specific conductance and $\mathrm{pH}$; and measured distribution coefficients of synthesized solutions - Continued

\begin{tabular}{|c|c|c|c|c|c|c|c|c|c|c|c|}
\hline Sample set & $\begin{array}{l}\text { Sample } \\
\text { number }\end{array}$ & $\begin{array}{l}\text { Sample } \\
\text { type }\end{array}$ & $\begin{array}{c}\text { Basalt mass } \\
\text { (grams) }\end{array}$ & Initial pH & Final pH & $\begin{array}{c}\text { Initial } \\
\text { conductivity } \\
(\mu \mathrm{S} / \mathrm{cm})\end{array}$ & $\begin{array}{c}\text { Final } \\
\text { conductivity } \\
(\mu \mathrm{S} / \mathrm{cm})\end{array}$ & $\begin{array}{c}\text { Initial Al } \\
\text { (mg/L) }\end{array}$ & $\begin{array}{c}\text { Final Al } \\
(\mathrm{mg} / \mathrm{L})\end{array}$ & $\begin{array}{c}\text { Initial Ca } \\
\text { (mg/L) }\end{array}$ & $\begin{array}{c}\text { Final Ca } \\
(\mathrm{mg} / \mathrm{L})\end{array}$ \\
\hline $123-14 b$ & 1 & 1 & 2.0233 & 8.22 & 8.21 & 874 & 504 & .04 & 1.07 & 13.03 & 12.74 \\
\hline $123-14 b$ & 2 & 1 & 2.0147 & 8.22 & 8.32 & 874 & 546 & .04 & 1.18 & 13.03 & 13.16 \\
\hline $123-14 b$ & 3 & 1 & 2.0137 & 8.22 & 8.18 & 874 & 635 & .04 & 1.23 & 13.03 & 13.69 \\
\hline $123-14 b$ & 5 & 1 & 2.0078 & 8.13 & 8.22 & 522 & 436 & .04 & 1.54 & 9.41 & 11.25 \\
\hline $123-14 b$ & 6 & 1 & 1.9903 & 8.13 & 8.19 & 522 & 516 & .04 & 1.82 & 9.41 & 11.12 \\
\hline $123-14 b$ & 7 & 1 & 2.0048 & 8.13 & 8.22 & 522 & 526 & .04 & 1.10 & 9.41 & 10.63 \\
\hline $123-14 b$ & 9 & 1 & 2.0001 & 8.18 & 8.10 & 593 & 597 & .04 & .84 & 10.41 & 11.89 \\
\hline $123-14 b$ & 10 & 1 & 2.0035 & 8.18 & 8.12 & 593 & 441 & .04 & 1.09 & 10.41 & 12.21 \\
\hline $123-14 b$ & 11 & 1 & 1.9915 & 8.18 & 8.20 & 593 & 515 & .04 & 1.22 & 10.41 & 12.03 \\
\hline $123-14 b$ & 13 & 1 & 1.9978 & 7.76 & 8.18 & 511 & 474 & .04 & 1.27 & 9.61 & 11.39 \\
\hline $123-14 b$ & 14 & 1 & 2.0017 & 7.76 & 8.08 & 511 & 329 & .04 & 1.04 & 9.61 & 11.39 \\
\hline $123-14 b$ & 15 & 1 & 2.0083 & 7.76 & 8.07 & 511 & 535 & .04 & 1.45 & 9.61 & 11.53 \\
\hline $123-14 b$ & 4 & 2 & & 8.05 & 8.22 & 545 & 487 & .04 & .04 & 10.20 & 13.03 \\
\hline $123-14 b$ & 8 & 2 & & 7.99 & 8.13 & 533 & 522 & .05 & .04 & 9.68 & 9.41 \\
\hline $123-14 \mathrm{~b}$ & 12 & 2 & & 8.02 & 8.18 & 506 & 593. & .05 & .04 & 10.19 & 10.41 \\
\hline $123-14 b$ & 16 & 2 & & 8.01 & 7.76 & 525 & 511 & .04 & .04 & 10.45 & 9.61 \\
\hline $123-14 b$ & 17 & 3 & & 5.35 & 6.28 & 2 & 620 & .00 & .01 & .17 & .16 \\
\hline
\end{tabular}


Table 6. Basalt mass; initial and final aluminum, calcium, iron, magnesium, potassium, sodium, and strontium concentrations; initial and final specific conductance and $\mathrm{pH}$; and measured distribution coefficients of synthesized solutions - Continued

\begin{tabular}{|c|c|c|c|c|c|c|c|c|c|c|c|c|c|c|}
\hline $\begin{array}{c}\text { Sample } \\
\text { set }\end{array}$ & $\begin{array}{l}\text { Sample } \\
\text { number }\end{array}$ & $\begin{array}{c}\text { Sample } \\
\text { type }\end{array}$ & $\begin{array}{c}\text { Initial } \\
\mathbf{F e} \\
(\mathrm{mg} / \mathrm{L})\end{array}$ & $\begin{array}{c}\text { Final Fe } \\
(\mathrm{mg} / \mathrm{L})\end{array}$ & $\begin{array}{c}\text { Initial } \\
\mathbf{M g} \\
(\mathrm{mg} / \mathrm{L})\end{array}$ & $\begin{array}{c}\text { Final } \\
\mathbf{M g} \\
(\mathrm{mg} / \mathrm{L})\end{array}$ & $\begin{array}{c}\text { Initial K } \\
(\mathrm{mg} / \mathrm{L})\end{array}$ & $\begin{array}{c}\text { Final K } \\
(\mathrm{mg} / \mathrm{L})\end{array}$ & $\begin{array}{c}\text { Initial } \\
\mathbf{N a} \\
(\mathrm{mg} / \mathbf{L})\end{array}$ & $\begin{array}{c}\text { Final } \\
\mathrm{Na} \\
(\mathrm{mg} / \mathrm{L})\end{array}$ & $\begin{array}{c}\text { Initial } \\
\mathrm{Sr} \\
(\mathrm{mg} / \mathrm{L})\end{array}$ & $\begin{array}{c}\text { Final Sr } \\
(\mathrm{mg} / \mathrm{L})\end{array}$ & $\Delta \mathbf{S r}$ & Sr Kd \\
\hline $123-14 b$ & 1 & 1 & .00 & .71 & 1.96 & 2.48 & 3.09 & 3.476 & 110.9 & 110.1 & .00 & .05 & -.05 & -9.53 \\
\hline $123-14 b$ & 2 & 1 & .00 & 1.07 & 1.96 & 2.74 & 3.09 & 3.477 & 110.9 & 110.2 & .00 & .05 & -.04 & -9.56 \\
\hline $123-14 b$ & 3 & 1 & .00 & .86 & 1.96 & 2.52 & 3.09 & 3.551 & 110.9 & 107.8 & .00 & .05 & -.05 & -9.58 \\
\hline $123-14 b$ & 5 & 1 & .01 & 1.14 & 1.91 & 2.47 & 2.25 & 2.905 & 104.5 & 104.6 & .99 & .54 & .45 & 8.40 \\
\hline $123-14 b$ & 6 & 1 & .01 & 1.55 & 1.91 & 2.59 & 2.25 & 2.896 & 104.5 & 104.3 & .99 & .52 & .46 & 8.84 \\
\hline $123-14 b$ & 7 & 1 & .01 & .93 & 1.91 & 2.40 & 2.25 & 2.740 & 104.5 & 102.7 & .99 & .52 & .47 & 9.07 \\
\hline $123-14 b$ & 9 & 1 & .01 & .53 & 1.97 & 2.48 & 2.40 & 2.890 & 103.9 & 103.6 & 2.56 & 1.42 & 1.14 & 8.07 \\
\hline $123-14 b$ & 10 & 1 & .01 & .73 & 1.97 & 2.51 & 2.40 & 2.935 & 103.9 & 105.0 & 2.56 & 1.40 & 1.16 & 8.22 \\
\hline $123-14 b$ & 11 & 1 & .01 & .84 & 1.97 & 2.54 & 2.40 & 2.929 & 103.9 & 104.8 & 2.56 & 1.37 & 1.19 & 8.72 \\
\hline $123-14 b$ & 13 & 1 & .01 & .90 & 1.91 & 2.52 & 2.29 & 2.855 & 102.5 & 102.0 & 4.86 & 2.78 & 2.08 & 7.50 \\
\hline $123-14 b$ & 14 & 1 & .01 & .69 & 1.91 & 2.42 & 2.29 & 2.839 & 102.5 & 104.4 & 4.86 & 2.83 & 2.03 & 7.18 \\
\hline $123-14 b$ & 15 & 1 & .01 & 1.63 & 1.91 & 2.46 & 2.29 & 2.845 & 102.5 & 103.2 & 4.86 & 2.82 & 2.04 & 7.20 \\
\hline $123-14 b$ & 4 & 2 & .01 & .00 & 1.86 & 1.96 & 3.02 & 3.087 & 105.2 & 110.9 & .00 & .00 & .00 & \\
\hline $123-14 b$ & 8 & 2 & .01 & .01 & 1.69 & 1.91 & 2.35 & 2.246 & 92.0 & 104.5 & .92 & .99 & -.07 & \\
\hline $123-14 b$ & 12 & 2 & .01 & .01 & 1.84 & 1.97 & 2.44 & 2.396 & 99.5 & 103.9 & 2.50 & 2.56 & -.06 & \\
\hline $123-14 b$ & 16 & 2 & .01 & .01 & 1.75 & 1.91 & 2.34 & 2.285 & 99.9 & 102.5 & 5.01 & 4.86 & .14 & \\
\hline $123-14 b$ & 17 & 3 & -.01 & .01 & .00 & .01 & .12 & .141 & -.7 & .5 & .00 & .00 & .00 & \\
\hline
\end{tabular}


Table 6. Basalt mass; initial and final aluminum, calcium, iron, magnesium, potassium, sodium, and strontium concentrations; initial and final specific conductance and $\mathrm{pH}$; and measured distribution coefficients of synthesized solutions - Continued

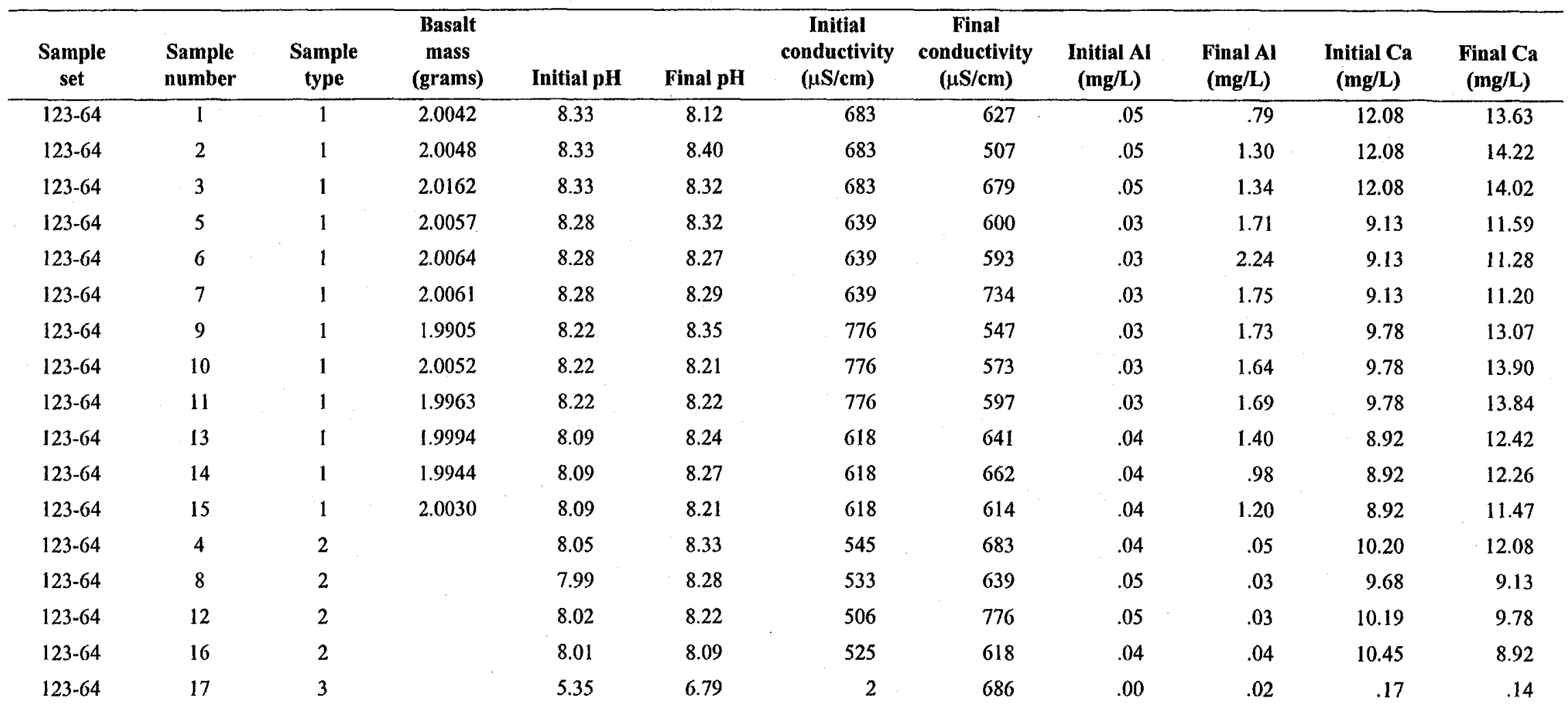


Table 6. Basalt mass; initial and final aluminum, calcium, iron, magnesium, potassium, sodium, and strontium concentrations; initial and final specific conductance and $\mathrm{pH}$; and measured distribution coefficients of synthesized solutions - Continued

\begin{tabular}{|c|c|c|c|c|c|c|c|c|c|c|c|c|c|c|}
\hline $\begin{array}{c}\text { Sample } \\
\text { set }\end{array}$ & $\begin{array}{l}\text { Sample } \\
\text { number }\end{array}$ & $\begin{array}{c}\text { Sample } \\
\text { type }\end{array}$ & $\begin{array}{c}\text { Initial } \\
\text { Fe } \\
(\mathrm{mg} / \mathrm{L})\end{array}$ & $\begin{array}{c}\text { Final Fe } \\
(\mathrm{mg} / \mathrm{L})\end{array}$ & $\begin{array}{c}\text { Initial } \\
\mathbf{M g} \\
(\mathrm{mg} / \mathrm{L})\end{array}$ & $\begin{array}{c}\text { Final } \\
\text { Mg } \\
(\mathbf{m g} / \mathbf{L})\end{array}$ & $\begin{array}{c}\text { Initial } \\
\mathbf{K} \\
(\mathbf{m g} / \mathbf{L})\end{array}$ & $\begin{array}{c}\text { Final K } \\
(\mathrm{mg} / \mathrm{L})\end{array}$ & $\begin{array}{c}\text { Initial } \\
\mathrm{Na} \\
(\mathrm{mg} / \mathrm{L})\end{array}$ & $\begin{array}{c}\text { Final } \\
\mathrm{Na} \\
(\mathrm{mg} / \mathrm{L})\end{array}$ & $\begin{array}{c}\text { Initial } \\
\mathrm{Sr} \\
(\mathrm{mg} / \mathrm{L})\end{array}$ & $\begin{array}{c}\text { Final Sr } \\
(\mathrm{mg} / \mathrm{L})\end{array}$ & $\Delta \mathrm{Sr}$ & Sr Kd \\
\hline $123-64$ & 1 & 1 & .01 & .52 & 1.79 & 2.62 & 3.03 & 4.09 & 98.4 & 102.8 & .00 & .07 & -.07 & -9.78 \\
\hline $123-64$ & 2 & 1 & .01 & .87 & 1.79 & 2.84 & 3.03 & 4.11 & 98.4 & 106.6 & .00 & .08 & -.08 & -9.78 \\
\hline $123-64$ & 3 & 1 & .01 & 1.10 & 1.79 & 2.89 & 3.03 & 4.02 & 98.4 & 104.0 & .00 & .08 & -.07 & -9.72 \\
\hline $123-64$ & 5 & 1 & .01 & 1.62 & 1.87 & 2.75 & 2.29 & 3.59 & 95.1 & 100.1 & .97 & .45 & .52 & 11.74 \\
\hline $123-64$ & 6 & 1 & .01 & 2.58 & 1.87 & 2.75 & 2.29 & 3.57 & 95.1 & 96.4 & .97 & .42 & .55 & 13.08 \\
\hline $123-64$ & 7 & 1 & .01 & 1.29 & 1.87 & 2.60 & 2.29 & 3.47 & 95.1 & 94.6 & .97 & .43 & .54 & 12.30 \\
\hline $123-64$ & 9 & 1 & .02 & 3.16 & 1.83 & 3.99 & 2.25 & 3.44 & 96.5 & 97.4 & 2.44 & 1.16 & 1.28 & 11.11 \\
\hline $123-64$ & 10 & 1 & .02 & 7.57 & 1.83 & 6.48 & 2.25 & 3.51 & 96.5 & 96.5 & 2.44 & 1.19 & 1.25 & 10.50 \\
\hline $123-64$ & 11 & 1 & .02 & 3.87 & 1.83 & 4.82 & 2.25 & 3.56 & 96.5 & 98.8 & 2.44 & 1.22 & 1.22 & 10.02 \\
\hline $123-64$ & 13 & 1 & .01 & 1.10 & 1.73 & 2.73 & 2.24 & 3.67 & 93.0 & 95.7 & 4.54 & 2.31 & 2.23 & 9.64 \\
\hline $123-64$ & 14 & 1 & .01 & .86 & 1.73 & 2.69 & 2.24 & 2.96 & 93.0 & 96.5 & 4.54 & 2.20 & 2.34 & 10.68 \\
\hline $123-64$ & 15 & 1 & .01 & .99 & 1.73 & 2.64 & 2.24 & 3.39 & 93.0 & 91.7 & 4.54 & 2.17 & 2.37 & 10.87 \\
\hline $123-64$ & 4 & 2 & .00 & .01 & 1.86 & 1.79 & 3.02 & 3.03 & 105.2 & 98.4 & .00 & .00 & .00 & \\
\hline $123-64$ & 8 & 2 & .01 & .01 & 1.69 & 1.87 & 2.35 & 2.29 & 92.0 & 95.1 & .92 & .97 & -.05 & \\
\hline $123-64$ & 12 & 2 & .01 & .02 & 1.84 & 1.83 & 2.44 & 2.25 & 99.5 & 96.5 & 2.50 & 2.44 & .06 & \\
\hline $123-64$ & 16 & 2 & .01 & .01 & 1.75 & 1.73 & 2.34 & 2.24 & 99.9 & 93.0 & 5.01 & 4.54 & .47 & \\
\hline $123-64$ & 17 & 3 & -.01 & .01 & .00 & .01 & .12 & .15 & -.7 & .5 & .00 & .00 & .00 & \\
\hline
\end{tabular}


Table 6. Basalt mass; initial and final aluminum, calcium, iron, magnesium, potassium, sodium, and strontium concentrations; initial and final specific conductance and $\mathrm{pH}$; and measured distribution coefficients of synthesized solutions - Continued

\begin{tabular}{|c|c|c|c|c|c|c|c|c|c|c|c|}
\hline $\begin{array}{l}\text { Sample } \\
\text { set }\end{array}$ & $\begin{array}{l}\text { Sample } \\
\text { number }\end{array}$ & $\begin{array}{c}\text { Sample } \\
\text { type }\end{array}$ & $\begin{array}{l}\text { Basalt mass } \\
\text { (grams) }\end{array}$ & Initial pH & Final pH & $\begin{array}{c}\text { Initial } \\
\text { conductivity } \\
(\mu \mathrm{S} / \mathrm{cm})\end{array}$ & $\begin{array}{c}\text { Final } \\
\text { conductivity } \\
(\mu \mathrm{S} / \mathrm{cm})\end{array}$ & $\begin{array}{c}\text { Initial Al } \\
(\mathbf{m g} / \mathbf{L})\end{array}$ & $\begin{array}{c}\text { Final Al } \\
(\mathrm{mg} / \mathrm{L})\end{array}$ & $\begin{array}{c}\text { Initial Ca } \\
(\mathrm{mg} / \mathrm{L})\end{array}$ & $\begin{array}{c}\text { Final Ca } \\
(\mathrm{mg} / \mathrm{L})\end{array}$ \\
\hline $123-68$ & 1 & 1 & 1.9946 & 8.39 & 8.28 & 650 & 746 & .05 & 1.21 & 12.72 & 13.81 \\
\hline $123-68$ & 3 & 1 & 2.0068 & 8.39 & 8.31 & 650 & 583 & .05 & 1.20 & 12.72 & 13.71 \\
\hline $123-68$ & 5 & 1 & 2.0038 & 8.28 & 8.18 & 733 & 566 & .03 & 1.71 & 8.79 & 9.86 \\
\hline $123-68$ & 6 & 1 & 2.0062 & 8.28 & 8.31 & 733 & 579 & .03 & 1.82 & 8.79 & 10.28 \\
\hline $123-68$ & 9 & 1 & 1.9962 & 8.25 & 8.20 & 585 & 612 & .30 & 1.56 & 10.49 & 11.14 \\
\hline $123-68$ & 10 & 1 & 1.9963 & 8.25 & 8.19 & 585 & 645 & .30 & 1.34 & 10.49 & 10.96 \\
\hline $123-68$ & 11 & 1 & 1.9930 & 8.25 & 8.24 & 585 & 395 & .30 & 1.25 & 10.49 & 11.09 \\
\hline $123-68$ & 13 & 1 & 2.0000 & 8.12 & 8.13 & 560 & 653 & .03 & 1.10 & 9.44 & 11.24 \\
\hline $123-68$ & 14 & 1 & 1.9993 & 8.12 & 8.09 & 560 & 438 & .03 & 1.12 & 9.44 & 11.05 \\
\hline $123-68$ & 15 & 1 & 1.9944 & 8.12 & 8.25 & 560 & 524 & .03 & 1.07 & 9.44 & 10.56 \\
\hline $123-68$ & 16 & 2 & & 8.01 & 8.12 & 525 & 560 & .04 & .03 & 10.45 & 9.44 \\
\hline $123-68$ & 17 & 3 & & 5.35 & 7.28 & 2 & 353 & .00 & .00 & .17 & .14 \\
\hline
\end{tabular}


Table 6. Basalt mass; initial and final aluminum, calcium, iron, magnesium, potassium, sodium, and strontium concentrations; initial and final specific conductance and $\mathrm{pH}$; and measured distribution coefficients of synthesized solutions - Continued

\begin{tabular}{|c|c|c|c|c|c|c|c|c|c|c|c|c|c|c|}
\hline $\begin{array}{c}\text { Sample } \\
\text { set }\end{array}$ & $\begin{array}{l}\text { Sample } \\
\text { number }\end{array}$ & $\begin{array}{c}\text { Sample } \\
\text { type }\end{array}$ & $\begin{array}{c}\text { Initial } \\
\mathrm{Fe} \\
(\mathrm{mg} / \mathrm{L})\end{array}$ & $\begin{array}{c}\text { Final Fe } \\
(\mathrm{mg} / \mathrm{L})\end{array}$ & $\begin{array}{c}\text { Initial } \\
\mathbf{M g} \\
\text { (mg/L) }\end{array}$ & $\begin{array}{c}\text { Final } \\
\mathrm{Mg} \\
(\mathrm{mg} / \mathrm{L})\end{array}$ & $\begin{array}{c}\text { Initial } \\
\mathbf{K} \\
(\mathrm{mg} / \mathrm{L})\end{array}$ & $\begin{array}{c}\text { Final K } \\
(\mathrm{mg} / \mathrm{L})\end{array}$ & $\begin{array}{c}\text { Initial } \\
\mathrm{Na} \\
(\mathrm{mg} / \mathrm{L})\end{array}$ & $\begin{array}{c}\text { Final } \\
\mathrm{Na} \\
(\mathrm{mg} / \mathrm{L})\end{array}$ & $\begin{array}{c}\text { Initial } \\
\mathrm{Sr} \\
(\mathrm{mg} / \mathrm{L})\end{array}$ & $\begin{array}{c}\text { Final Sr } \\
(\mathbf{m g} / \mathbf{L})\end{array}$ & $\Delta \mathrm{Sr}$ & Sr Kd \\
\hline $123-68$ & 1 & 1 & .00 & .36 & 1.67 & 2.39 & 3.07 & 3.93 & 94.4 & 105.7 & .00 & .05 & -.05 & -9.76 \\
\hline $123-68$ & 2 & 1 & .00 & .32 & 1.67 & 2.28 & 3.07 & 3.78 & 94.4 & 103.8 & .00 & .05 & -.05 & -9.76 \\
\hline $123-68$ & 3 & 1 & .00 & 1.62 & 1.67 & 2.91 & 3.07 & 3.82 & 94.4 & 103.9 & .00 & .05 & -.05 & -9.70 \\
\hline $123-68$ & 5 & 1 & .02 & .68 & 1.78 & 2.21 & 2.36 & 3.22 & 97.9 & 97.0 & .94 & .48 & .46 & 9.56 \\
\hline $123-68$ & 6 & 1 & .02 & .68 & 1.78 & 2.28 & 2.36 & 2.89 & 97.9 & 101.3 & .94 & .50 & .44 & 8.70 \\
\hline $123-68$ & 7 & 1 & .02 & .59 & 1.78 & 2.28 & 2.36 & 3.20 & 97.9 & 98.4 & .94 & .52 & .42 & 8.16 \\
\hline $123-68$ & 9 & 1 & .02 & .59 & 1.91 & 2.25 & 2.36 & 3.47 & 99.7 & 96.6 & 2.60 & 1.33 & 1.27 & 9.62 \\
\hline $123-68$ & 10 & 1 & .02 & .52 & 1.91 & 2.26 & 2.36 & 3.22 & 99.7 & 100.5 & 2.60 & 1.38 & 1.22 & 8.90 \\
\hline $123-68$ & 11 & 1 & .02 & .46 & 1.91 & 2.24 & 2.36 & 2.93 & 99.7 & 98.2 & 2.60 & 1.38 & 1.21 & 8.80 \\
\hline $123-68$ & 13 & 1 & .01 & .40 & 1.76 & 2.26 & 2.34 & 3.09 & 97.2 & 100.3 & 4.86 & 2.84 & 2.02 & 7.11 \\
\hline $123-68$ & 14 & 1 & .01 & .44 & 1.76 & 2.30 & 2.34 & 3.13 & 97.2 & 99.6 & 4.86 & 2.78 & 2.07 & 7.44 \\
\hline $123-68$ & 15 & 1 & .01 & .68 & 1.76 & 2.24 & 2.34 & 3.08 & 97.2 & 93.5 & 4.86 & 2.70 & 2.15 & 8.00 \\
\hline $123-68$ & 4 & 2 & .00 & .00 & 1.86 & 1.67 & 3.02 & 3.07 & 105.2 & 94.4 & .00 & .00 & .00 & \\
\hline $123-68$ & 8 & 2 & .01 & .02 & 1.69 & 1.78 & 2.35 & 2.36 & 92.0 & 97.9 & .92 & .94 & -.02 & \\
\hline $123-68$ & 12 & 2 & .01 & .02 & 1.84 & 1.91 & 2.44 & 2.36 & 99.5 & 99.7 & 2.50 & 2.60 & -.10 & \\
\hline $123-68$ & 16 & 2 & .01 & .01 & 1.75 & 1.76 & 2.34 & 2.34 & 99.9 & 97.2 & 5.01 & 4.86 & .15 & \\
\hline $123-68$ & 17 & 3 & -.01 & .01 & .00 & .01 & .12 & .24 & -.7 & .6 & .00 & .00 & .00 & \\
\hline
\end{tabular}


Table 6. Basalt mass; initial and final aluminum, calcium, iron, magnesium, potassium, sodium, and strontium concentrations; initial and final specific conductance and $\mathrm{pH}$; and measured distribution coefficients of synthesized solutions - Continued

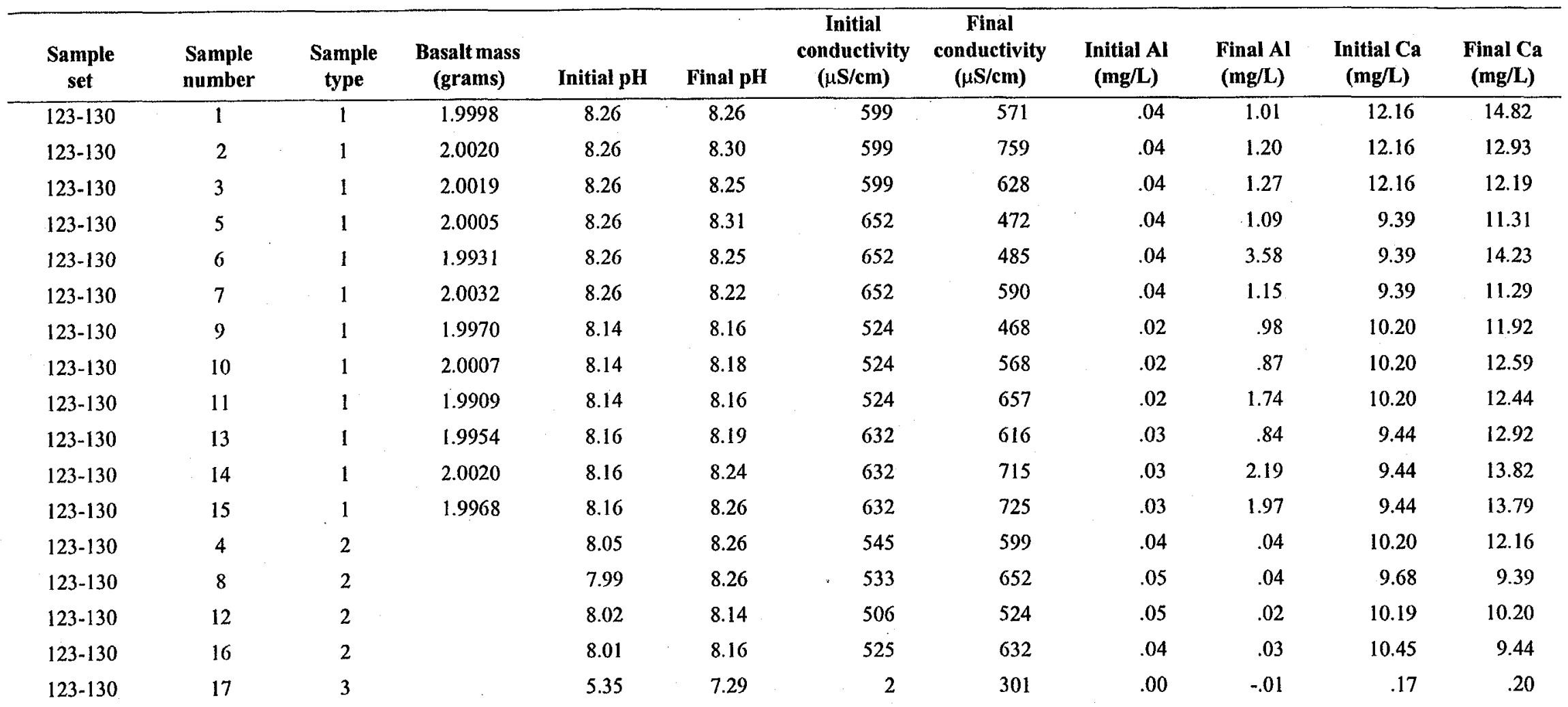


Table 6. Basalt mass; initial and final aluminum, calcium, iron, magnesium, potassium, sodium, and strontium concentrations; initial and final specific conductance and $\mathrm{pH}$; and measured distribution coefficients of synthesized solutions - Continued

\begin{tabular}{|c|c|c|c|c|c|c|c|c|c|c|c|c|c|c|}
\hline $\begin{array}{c}\text { Sample } \\
\text { set }\end{array}$ & $\begin{array}{l}\text { Sample } \\
\text { number }\end{array}$ & $\begin{array}{c}\text { Sample } \\
\text { type }\end{array}$ & $\begin{array}{c}\text { Initial } \\
\text { Fe } \\
\text { (mg/L) }\end{array}$ & $\begin{array}{c}\text { Final Fe } \\
\text { (mg/L) }\end{array}$ & $\begin{array}{c}\text { Initial } \\
\mathrm{Mg} \\
(\mathrm{mg} / \mathrm{L})\end{array}$ & $\begin{array}{c}\text { Final } \\
\text { Mg } \\
\text { (mg/L) }\end{array}$ & $\begin{array}{c}\text { Initial } \\
\mathrm{K} \\
(\mathrm{mg} / \mathrm{L})\end{array}$ & $\begin{array}{c}\text { Final K } \\
(\mathrm{mg} / \mathrm{L})\end{array}$ & $\begin{array}{c}\text { Initial } \\
\text { Na } \\
\text { (mg/L) }\end{array}$ & $\begin{array}{c}\text { Final } \\
\text { Na } \\
\text { (mg/L) }\end{array}$ & $\begin{array}{c}\text { Initial } \\
\mathrm{Sr} \\
(\mathrm{mg} / \mathrm{L})\end{array}$ & $\begin{array}{c}\text { Final Sr } \\
(\mathrm{mg} / \mathrm{L})\end{array}$ & $\Delta \mathbf{S r}$ & Sr Kd \\
\hline $123-130$ & 1 & 1 & .00 & .57 & 1.99 & 2.66 & 3.17 & 3.79 & 110.0 & 109.5 & .00 & .04 & -.04 & -9.65 \\
\hline $123-130$ & 2 & 1 & .00 & .82 & 1.99 & 2.72 & 3.17 & 3.86 & 110.0 & 106.3 & .00 & .04 & -.04 & -9.63 \\
\hline $123-130$ & 3 & 1 & .00 & .91 & 1.99 & 2.75 & 3.17 & 3.76 & 110.0 & 100.8 & .00 & .04 & -.04 & -9.59 \\
\hline $123-130$ & 5 & 1 & .00 & .54 & 1.88 & 2.70 & 2.31 & 3.01 & 103.4 & 108.3 & .96 & .63 & .33 & 5.26 \\
\hline $123-130$ & 6 & 1 & .00 & 5.79 & 1.88 & 6.06 & 2.31 & 3.09 & 103.4 & 105.5 & .96 & .64 & .32 & 5.02 \\
\hline $123-130$ & 7 & 1 & .00 & 1.46 & 1.88 & 3.18 & 2.31 & 3.00 & 103.4 & 104.6 & .96 & .61 & .35 & 5.78 \\
\hline $123-130$ & 9 & 1 & .00 & .94 & 1.85 & 2.72 & 2.45 & 3.23 & 103.0 & 101.4 & 2.49 & 1.65 & .84 & 5.09 \\
\hline $123-130$ & 10 & 1 & .00 & 1.07 & 1.85 & 3.00 & 2.45 & 3.15 & 103.0 & 101.1 & 2.49 & 1.68 & .82 & 4.87 \\
\hline $123-130$ & 11 & 1 & .00 & 1.22 & 1.85 & 3.04 & 2.45 & 3.13 & 103.0 & 102.8 & 2.49 & 1.65 & .84 & 5.11 \\
\hline $123-130$ & 13 & 1 & .00 & .37 & 1.80 & 2.85 & 2.32 & 2.90 & 101.1 & 113.3 & 4.86 & 3.50 & 1.37 & 3.92 \\
\hline $123-130$ & 14 & 1 & .00 & 1.82 & 1.80 & 3.66 & 2.32 & 2.83 & 101.1 & 109.4 & 4.86 & 3.58 & 1.29 & 3.60 \\
\hline $123-130$ & 15 & 1 & .00 & 3.74 & 1.80 & 4.64 & 2.32 & 2.86 & 101.1 & 112.3 & 4.86 & 3.65 & 1.21 & 3.33 \\
\hline $123-130$ & 4 & 2 & .00 & .00 & 1.86 & 1.99 & 3.02 & 3.17 & 105.2 & 110.0 & .00 & .00 & .00 & \\
\hline $123-130$ & 8 & 2 & .01 & .00 & 1.69 & 1.88 & 2.35 & 2.31 & 92.0 & 103.4 & .92 & .96 & -.04 & \\
\hline $123-130$ & 12 & 2 & .01 & .00 & 1.84 & 1.85 & 2.44 & 2.45 & 99.5 & 103.0 & 2.50 & 2.49 & .01 & \\
\hline $123-130$ & 16 & 2 & .01 & .00 & 1.75 & 1.80 & 2.34 & 2.32 & 99.9 & 101.1 & 5.01 & 4.86 & .14 & \\
\hline $123-130$ & 17 & 3 & -.01 & .00 & .00 & .01 & .12 & .32 & -.7 & .0 & .00 & .00 & .00 & \\
\hline
\end{tabular}


Table 6. Basalt mass; initial and final aluminum, calcium, iron, magnesium, potassium, sodium, and strontium concentrations; initial and final specific conductance and $\mathrm{pH}$; and measured distribution coefficients of synthesized solutions - Continued

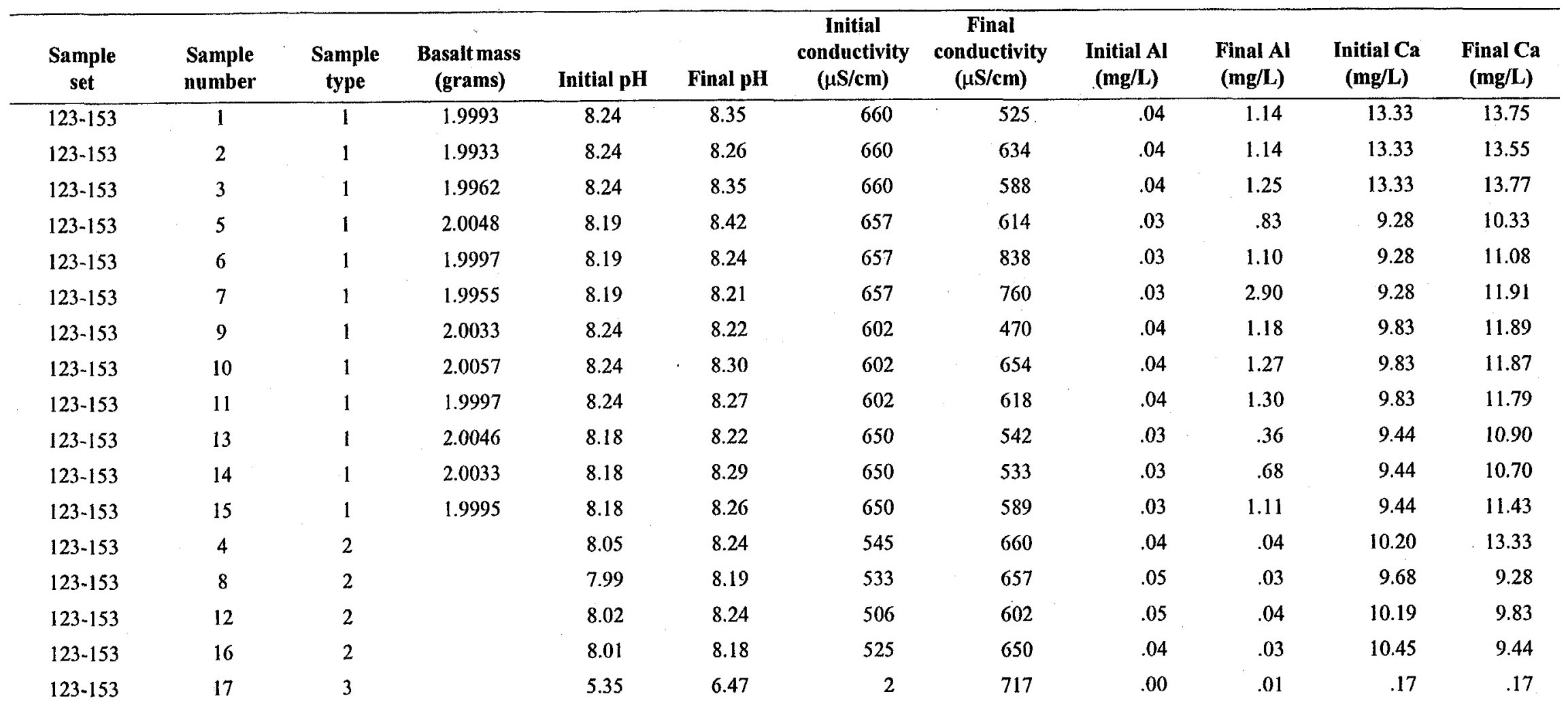


Table 6. Basalt mass; initial and final aluminum, calcium, iron, magnesium, potassium, sodium, and strontium concentrations; initial and final specific conductance and $\mathrm{pH}$; and measured distribution coefficients of synthesized solutions - Continued

\begin{tabular}{|c|c|c|c|c|c|c|c|c|c|c|c|c|c|c|}
\hline $\begin{array}{l}\text { Sample } \\
\text { set }\end{array}$ & $\begin{array}{l}\text { Sample } \\
\text { number }\end{array}$ & $\begin{array}{c}\text { Sample } \\
\text { type }\end{array}$ & $\begin{array}{c}\text { Initial } \\
\mathrm{Fe} \\
(\mathrm{mg} / \mathrm{L})\end{array}$ & $\begin{array}{c}\text { Final Fe } \\
(\mathrm{mg} / \mathrm{L})\end{array}$ & $\begin{array}{c}\text { Initial } \\
\mathbf{M g} \\
(\mathrm{mg} / \mathrm{L})\end{array}$ & $\begin{array}{c}\text { Final } \\
\mathrm{Mg} \\
(\mathrm{mg} / \mathrm{L})\end{array}$ & $\begin{array}{c}\text { Initial } \\
\mathbf{K} \\
(\mathrm{mg} / \mathrm{L})\end{array}$ & $\begin{array}{l}\text { Final K } \\
(\mathrm{mg} / \mathrm{L})\end{array}$ & $\begin{array}{c}\text { Initial } \\
\mathrm{Na} \\
(\mathrm{mg} / \mathrm{L})\end{array}$ & $\begin{array}{c}\text { Final } \\
\mathrm{Na} \\
(\mathrm{mg} / \mathrm{L})\end{array}$ & $\begin{array}{c}\text { Initial } \\
\mathrm{Sr} \\
(\mathbf{m g} / \mathrm{L})\end{array}$ & $\begin{array}{c}\text { Final Sr } \\
(\mathbf{m g} / \mathbf{L})\end{array}$ & $\Delta \mathbf{S r}$ & $\mathbf{S r} \mathbf{K d}$ \\
\hline $123-153$ & 1 & 1 & .00 & .54 & 1.92 & 2.86 & 3.02 & 3.55 & 109.9 & 111.9 & .00 & .04 & -.04 & -9.56 \\
\hline $123-153$ & 2 & 1 & .00 & .71 & 1.92 & 2.94 & 3.02 & 3.41 & 109.9 & 109.2 & .00 & .04 & -.04 & -9.56 \\
\hline $123-153$ & 3 & 1 & .00 & .46 & 1.92 & 2.89 & 3.02 & 3.27 & 109.9 & 109.6 & .00 & .04 & -.04 & -9.55 \\
\hline $123-153$ & 5 & 1 & .00 & .26 & 1.82 & 2.57 & 2.43 & 2.77 & 102.7 & 103.9 & 1.00 & .63 & .37 & 5.84 \\
\hline $123-153$ & 6 & 1 & .00 & .46 & 1.82 & 2.71 & 2.43 & 2.82 & 102.7 & 103.1 & 1.00 & .65 & .35 & 5.42 \\
\hline $123-153$ & 7 & 1 & .00 & .82 & 1.82 & 3.77 & 2.43 & 3.03 & 102.7 & 100.0 & 1.00 & .65 & .35 & 5.46 \\
\hline $123-153$ & 9 & 1 & .01 & .39 & 1.86 & 2.91 & 2.48 & 3.03 & 101.4 & 103.1 & 2.50 & 1.73 & .76 & 4.41 \\
\hline $123-153$ & 10 & 1 & .01 & .43 & 1.86 & 2.94 & 2.48 & 3.04 & 101.4 & 103.6 & 2.50 & 1.69 & .80 & 4.73 \\
\hline $123-153$ & 11 & 1 & .01 & .38 & 1.86 & 2.89 & 2.48 & 2.94 & 101.4 & 101.7 & 2.50 & 1.73 & .76 & 4.41 \\
\hline $123-153$ & 13 & 1 & .01 & .08 & 1.81 & 2.42 & 2.50 & 2.68 & 101.8 & 104.5 & 4.87 & 3.52 & 1.35 & 3.83 \\
\hline $123-153$ & 14 & 1 & .01 & .95 & 1.81 & 2.48 & 2.50 & 2.70 & 101.8 & 102.0 & 4.87 & 3.50 & 1.37 & 3.90 \\
\hline $123-153$ & 15 & 1 & .01 & .41 & 1.81 & 2.81 & 2.50 & 2.96 & 101.8 & 101.4 & 4.87 & 3.44 & 1.44 & 4.18 \\
\hline $123-153$ & 4 & 2 & .00 & .00 & 1.86 & 1.92 & 3.02 & 3.02 & 105.2 & 109.9 & .00 & .00 & .00 & \\
\hline $123-153$ & 8 & 2 & .01 & .00 & 1.69 & 1.82 & 2.35 & 2.43 & 92.0 & 102.7 & .92 & 1.00 & -.08 & \\
\hline $123-153$ & 12 & 2 & .01 & .01 & 1.84 & 1.86 & 2.44 & 2.48 & 99.5 & 101.4 & 2.50 & 2.50 & .01 & \\
\hline $123-153$ & 16 & 2 & .01 & .01 & 1.75 & 1.81 & 2.34 & 2.50 & 99.9 & 101.8 & 5.01 & 4.87 & .14 & \\
\hline $123-153$ & 17 & 3 & -.01 & .01 & .00 & .01 & .12 & .34 & -.7 & .3 & .00 & .00 & .00 & \\
\hline
\end{tabular}


Table 6. Basalt mass; initial and final aluminum, calcium, iron, magnesium, potassium, sodium, and strontium concentrations; initial and final specific conductance and $\mathrm{pH}$; and measured distribution coefficients of synthesized solutions - Continued

\begin{tabular}{|c|c|c|c|c|c|c|c|c|c|c|c|}
\hline $\begin{array}{l}\text { Sample } \\
\text { set }\end{array}$ & $\begin{array}{l}\text { Sample } \\
\text { number }\end{array}$ & $\begin{array}{l}\text { Sample } \\
\text { type }\end{array}$ & $\begin{array}{c}\text { Basalt mass } \\
\text { (grams) }\end{array}$ & Initial pH & Final pH & $\begin{array}{c}\text { Initial } \\
\text { conductivity } \\
(\mu \mathrm{S} / \mathrm{cm})\end{array}$ & $\begin{array}{c}\text { Final } \\
\text { conductivity } \\
(\mu \mathrm{S} / \mathrm{cm})\end{array}$ & $\begin{array}{c}\text { Initial Al } \\
(\mathbf{m g} / \mathbf{L})\end{array}$ & $\begin{array}{c}\text { Final Al } \\
(\mathbf{m g} / \mathbf{L})\end{array}$ & $\begin{array}{c}\text { Initial Ca } \\
\text { (mg/L) }\end{array}$ & $\begin{array}{c}\text { Final Ca } \\
(\mathrm{mg} / \mathrm{L})\end{array}$ \\
\hline $123-156$ & 1 & 1 & 1.9977 & 8.22 & 8.23 & 723 & 867 & .04 & 1.16 & 10.50 & 12.71 \\
\hline $123-156$ & 3 & 1 & 2.0005 & 8.22 & 8.40 & 723 & 546 & .04 & 1.20 & 10.50 & 11.88 \\
\hline $123-156$ & 5 & 1 & 1.9997 & 8.18 & 8.31 & 527 & 560 & .04 & 1.27 & 10.55 & 12.54 \\
\hline $123-156$ & 6 & 1 & 1.9966 & 8.18 & 8.26 & 527 & 581 & .04 & 1.37 & 10.55 & 12.37 \\
\hline $123-156$ & 10 & 1 & 2.0072 & 8.24 & 8.40 & 705 & 630 & .04 & .98 & 10.14 & 12.22 \\
\hline $123-156$ & 11 & 1 & 1.9951 & 8.24 & 8.27 & 705 & 782 & .04 & 1.22 & 10.14 & 11.94 \\
\hline $123-156$ & 13 & 1 & 2.0018 & 8.35 & 8.32 & 703 & 718 & .04 & .97 & 10.91 & 12.70 \\
\hline $123-156$ & 14 & 1 & 2.0071 & 8.35 & 8.31 & 703 & 425 & .04 & 3.43 & 10.91 & 14.54 \\
\hline $123-156$ & 15 & 1 & 2.0045 & 8.35 & 8.34 & 703 & 852 & .04 & .74 & 10.91 & 12.23 \\
\hline $123-156$ & 16 & 2 & & 8.00 & 8.35 & 563 & 703 & .04 & .04 & 10.45 & 10.91 \\
\hline $123-156$ & 17 & 3 & & 5.74 & 6.35 & 45 & 187 & .00 & .01 & .01 & .13 \\
\hline
\end{tabular}


Table 6. Basalt mass; initial and final aluminum, calcium, iron, magnesium, potassium, sodium, and strontium concentrations; initial and final specific conductance and $\mathrm{pH}$; and measured distribution coefficients of synthesized solutions - Continued

\begin{tabular}{|c|c|c|c|c|c|c|c|c|c|c|c|c|c|c|}
\hline $\begin{array}{l}\text { Sample } \\
\text { set }\end{array}$ & $\begin{array}{l}\text { Sample } \\
\text { number }\end{array}$ & $\begin{array}{c}\text { Sample } \\
\text { type }\end{array}$ & $\begin{array}{c}\text { Initial } \\
\mathrm{Fe} \\
(\mathrm{mg} / \mathrm{L})\end{array}$ & $\begin{array}{c}\text { Final Fe } \\
(\mathrm{mg} / \mathrm{L})\end{array}$ & $\begin{array}{c}\text { Initial } \\
\mathbf{M g} \\
(\mathrm{mg} / \mathrm{L})\end{array}$ & $\begin{array}{c}\text { Final } \\
\mathrm{Mg} \\
(\mathrm{mg} / \mathrm{L})\end{array}$ & $\begin{array}{c}\text { Initial } \\
\mathbf{K} \\
(\mathbf{m g} / \mathbf{L})\end{array}$ & $\begin{array}{c}\text { Final K } \\
(\mathrm{mg} / \mathrm{L})\end{array}$ & $\begin{array}{c}\text { Initial } \\
\mathrm{Na} \\
(\mathrm{mg} / \mathrm{L})\end{array}$ & $\begin{array}{c}\text { Final } \\
\mathrm{Na} \\
(\mathrm{mg} / \mathrm{L})\end{array}$ & $\begin{array}{c}\text { Initial } \\
\mathrm{Sr} \\
(\mathrm{mg} / \mathrm{L})\end{array}$ & $\begin{array}{c}\text { Final Sr } \\
(\mathrm{mg} / \mathrm{L})\end{array}$ & $\Delta \mathrm{Sr}$ & Sr Kd \\
\hline $123-156$ & 1 & 1 & -.01 & .53 & 1.86 & 2.93 & 3.13 & 3.67 & 104.6 & 108.1 & .00 & .05 & -.05 & -9.72 \\
\hline $123-156$ & 3 & 1 & -.01 & .81 & 1.86 & 2.98 & 3.13 & 3.70 & 104.6 & 105.9 & .00 & .04 & -.04 & -9.66 \\
\hline $123-156$ & 5 & 1 & -.01 & .72 & 1.87 & 2.99 & 2.42 & 2.94 & 102.1 & 100.7 & 1.03 & .68 & .35 & 5.06 \\
\hline $123-156$ & $\sigma$ & 1 & -.01 & .79 & 1.87 & 3.29 & 2.42 & 2.81 & 102.1 & 98.7 & 1.03 & .68 & .35 & 5.23 \\
\hline $123-156$ & 9 & 1 & -.01 & .66 & 1.85 & 2.78 & 2.50 & 2.88 & 98.6 & 99.5 & 2.61 & 1.70 & .91 & 5.33 \\
\hline $123-156$ & 10 & 1 & -.01 & .44 & 1.85 & 2.84 & 2.50 & 2.97 & 98.6 & 99.1 & 2.61 & 1.67 & .93 & 5.56 \\
\hline $123-156$ & 11 & 1 & -.01 & .49 & 1.85 & 2.94 & 2.50 & 2.88 & 98.6 & 99.3 & 2.61 & 1.68 & .93 & 5.57 \\
\hline $123-156$ & 13 & 1 & .00 & .48 & 1.86 & 2.85 & 2.40 & 2.95 & 102.3 & 103.4 & 5.28 & 3.69 & 1.59 & 4.29 \\
\hline $123-156$ & 14 & 1 & .00 & 3.29 & 1.86 & 6.74 & 2.40 & 2.92 & 102.3 & 102.0 & 5.28 & 3.69 & 1.59 & 4.28 \\
\hline $123-156$ & 15 & 1 & .00 & .43 & 1.86 & 2.65 & 2.40 & 2.80 & 102.3 & 102.0 & 5.28 & 3.65 & 1.63 & 4.46 \\
\hline $123-156$ & 16 & 2 & .01 & .00 & 1.75 & 1.86 & 2.34 & 2.40 & 99.9 & 102.3 & 5.01 & 5.28 & -.27 & \\
\hline $123-156$ & 17 & 3 & -.01 & .00 & .00 & .00 & .12 & .23 & -.8 & .2 & .00 & .00 & .00 & \\
\hline
\end{tabular}


Table 6. Basalt mass; initial and final aluminum, calcium, iron, magnesium, potassium, sodium, and strontium concentrations; initial and final specific conductance and $\mathrm{pH}$; and measured distribution coefficients of synthesized solutions - Continued

\begin{tabular}{|c|c|c|c|c|c|c|c|c|c|c|c|}
\hline $\begin{array}{l}\text { Sample } \\
\text { set }\end{array}$ & $\begin{array}{l}\text { Sample } \\
\text { number }\end{array}$ & $\begin{array}{c}\text { Sample } \\
\text { type }\end{array}$ & $\begin{array}{c}\text { Basalt mass } \\
\text { (grams) }\end{array}$ & Initial pH & Final pH & $\begin{array}{c}\text { Initial } \\
\text { conductivity } \\
(\mu \mathrm{S} / \mathrm{cm})\end{array}$ & $\begin{array}{c}\text { Final } \\
\text { conductivity } \\
(\mu \mathrm{S} / \mathrm{cm})\end{array}$ & $\underset{(\mathrm{mg} / \mathrm{L})}{\text { Initial Al }}$ & $\begin{array}{c}\text { Final Al } \\
(\mathrm{mg} / \mathrm{L})\end{array}$ & $\begin{array}{c}\text { Initial Ca } \\
\text { (mg/L) }\end{array}$ & $\begin{array}{c}\text { Final Ca } \\
(\mathrm{mg} / \mathrm{L})\end{array}$ \\
\hline $123-172$ & 1 & 1 & 2.0037 & 8.34 & 8.47 & 737 & 705 & .04 & .84 & 12.41 & 17.82 \\
\hline $123-172$ & 3 & 1 & 1.9995 & 8.34 & 8.44 & 737 & 677 & .04 & 2.82 & 12.41 & 20.51 \\
\hline $123-172$ & 5 & 1 & 2.0039 & 8.21 & 8.43 & 581 & 441 & .03 & .95 & 9.26 & 16.61 \\
\hline $123-172$ & 6 & 1 & 2.0031 & 8.21 & 8.39 & 581 & 636 & .03 & 1.01 & 9.26 & 15.70 \\
\hline $123-172$ & 9 & 1 & 2.0015 & 8.24 & 8.44 & 537 & 549 & .03 & 1.04 & 9.89 & 16.09 \\
\hline $123-172$ & 10 & 1 & 1.9997 & 8.24 & 8.36 & 537 & 505 & .03 & .75 & 9.89 & 16.23 \\
\hline $123-172$ & 11 & 1 & 1.9925 & 8.24 & 8.35 & 537 & 620 & .03 & .55 & 9.89 & 15.16 \\
\hline $123-172$ & 13 & 1 & 2.0040 & 8.25 & 8.33 & 552 & 499 & .03 & 1.07 & 9.47 & 16.63 \\
\hline $123-172$ & 14 & 1 & 2.0008 & 8.25 & 8.33 & 552 & 628 & .03 & .70 & 9.47 & 15.36 \\
\hline $123-172$ & 15 & 1 & 1.9925 & 8.25 & 8.34 & 552 & 712 & .03 & .64 & 9.47 & 14.88 \\
\hline $123-172$ & 16 & 2 & & 8.01 & 8.25 & 525 & 552 & .04 & .03 & 10.45 & 9.47 \\
\hline $123-172$ & 17 & 3 & & 5.35 & 7.73 & 2 & 232 & .00 & .00 & .17 & .17 \\
\hline
\end{tabular}


Table 6. Basalt mass; initial and final aluminum, calcium, iron, magnesium, potassium, sodium, and strontium concentrations; initial and final specific conductance and $\mathrm{pH}$; and measured distribution coefficients of synthesized solutions - Continued

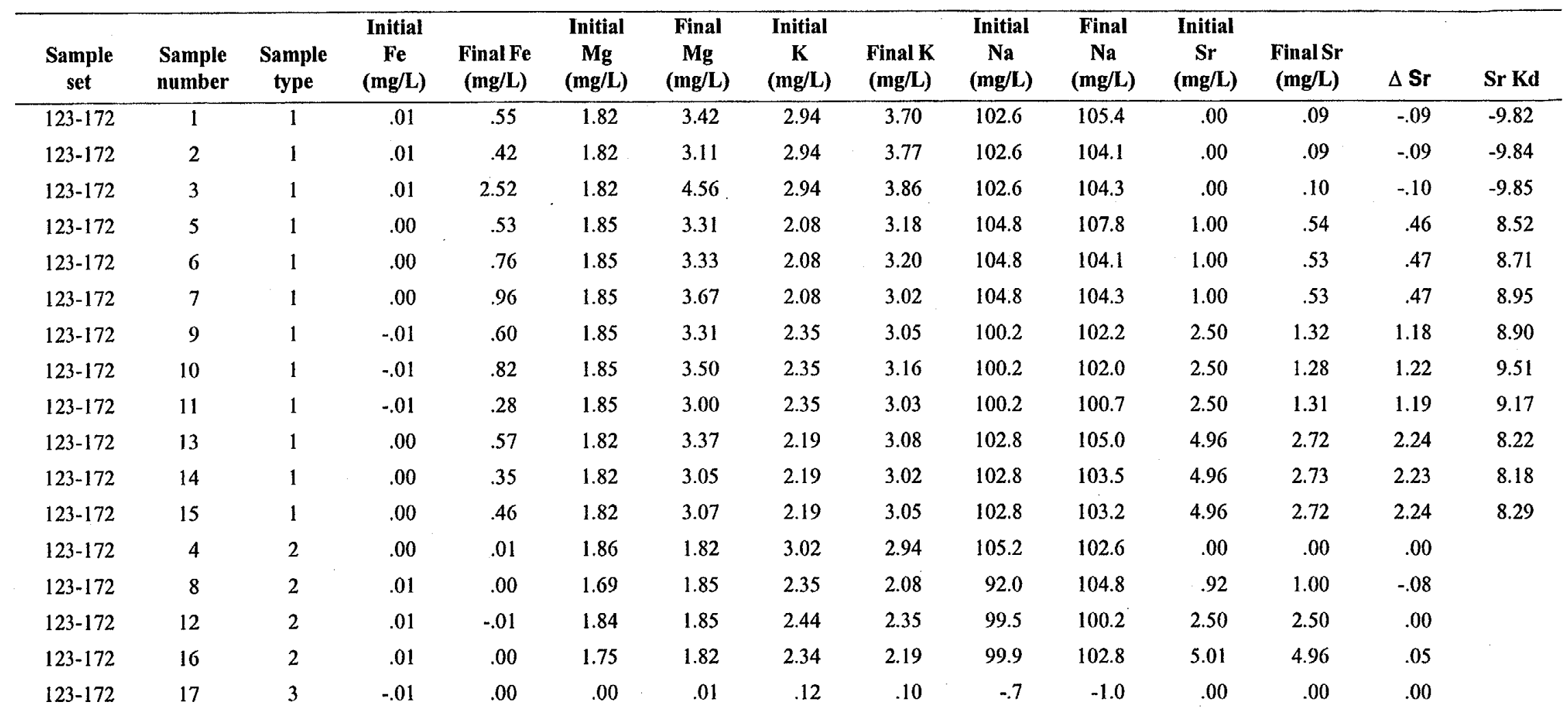


Table 6. Basalt mass; initial and final aluminum, calcium, iron, magnesium, potassium, sodium, and strontium concentrations; initial and final specific conductance and $\mathrm{pH}$; and measured distribution coefficients of synthesized solutions - Continued

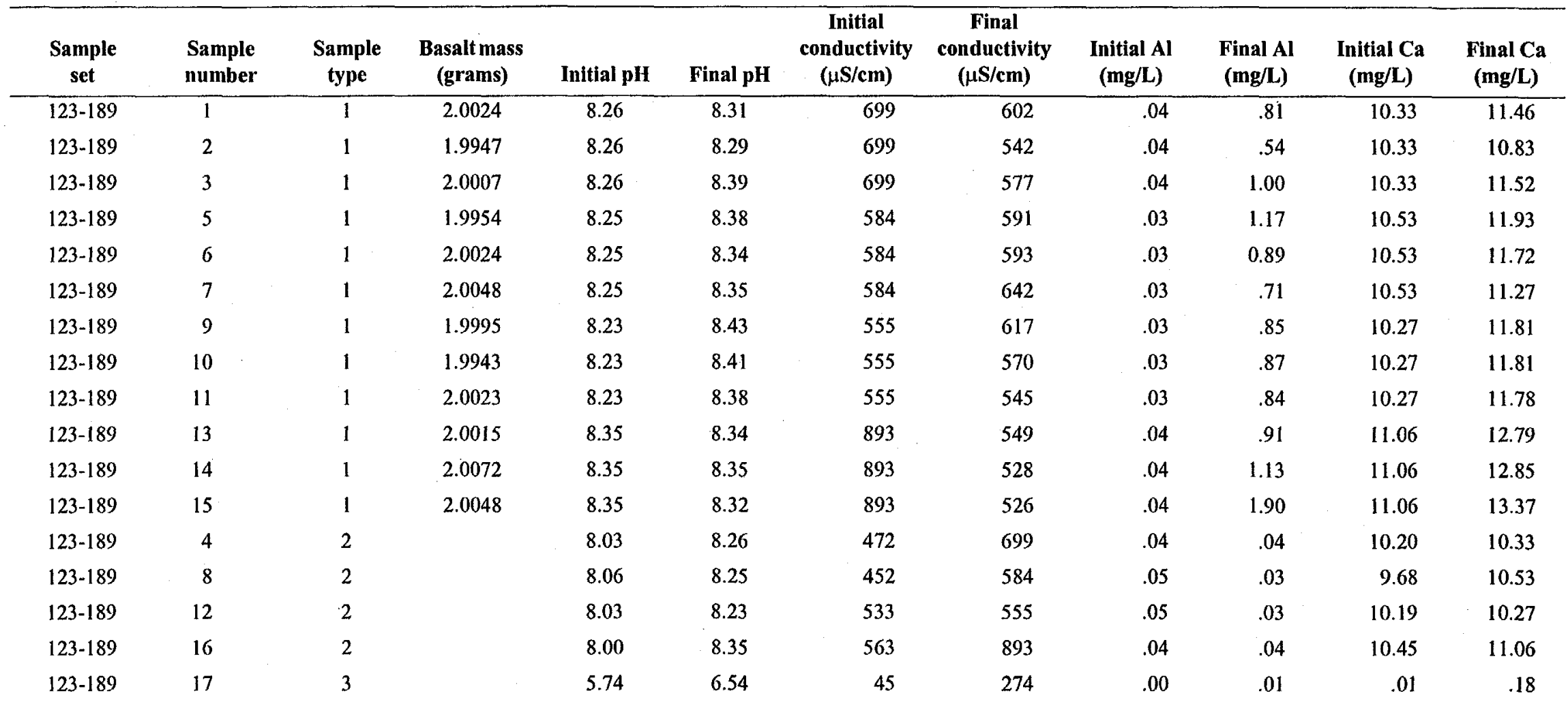


Table 6. Basalt mass; initial and final aluminum, calcium, iron, magnesium, potassium, sodium, and strontium concentrations; initial and final specific conductance and $\mathrm{pH}$; and measured distribution coefficients of synthesized solutions - Continued

\begin{tabular}{|c|c|c|c|c|c|c|c|c|c|c|c|c|c|c|}
\hline $\begin{array}{c}\text { Sample } \\
\text { set }\end{array}$ & $\begin{array}{l}\text { Sample } \\
\text { number }\end{array}$ & $\begin{array}{c}\text { Sample } \\
\text { type }\end{array}$ & $\begin{array}{c}\text { Initial } \\
\text { Fe } \\
(\mathrm{mg} / \mathrm{L})\end{array}$ & $\begin{array}{c}\text { Final Fe } \\
(\mathrm{mg} / \mathrm{L})\end{array}$ & $\begin{array}{c}\text { Initial } \\
\mathrm{Mg} \\
(\mathrm{mg} / \mathrm{L})\end{array}$ & $\begin{array}{c}\text { Final } \\
\mathrm{Mg} \\
(\mathrm{mg} / \mathrm{L})\end{array}$ & $\begin{array}{c}\text { Initial } \\
\mathbf{K} \\
(\mathrm{mg} / \mathrm{L})\end{array}$ & $\begin{array}{c}\text { Final K } \\
(\mathbf{m g} / \mathbf{L})\end{array}$ & $\begin{array}{c}\text { Initial } \\
\mathrm{Na} \\
(\mathrm{mg} / \mathrm{L})\end{array}$ & $\begin{array}{c}\text { Final } \\
\mathrm{Na} \\
(\mathrm{mg} / \mathrm{L})\end{array}$ & $\begin{array}{c}\text { Initial } \\
\mathrm{Sr} \\
(\mathrm{mg} / \mathrm{L})\end{array}$ & $\begin{array}{c}\text { Final Sr } \\
(\mathrm{mg} / \mathrm{L})\end{array}$ & $\Delta \mathbf{S r}$ & Sr Kd \\
\hline 123-189 & 1 & 1 & .02 & .42 & 1.90 & 3.12 & 3.05 & 3.37 & 106.6 & 112.2 & .00 & .04 & -.04 & -9.62 \\
\hline $123-189$ & 2 & 1 & .02 & .27 & 1.90 & 2.71 & 3.05 & 3.31 & 106.6 & 110.6 & .00 & .04 & -.03 & -9.64 \\
\hline $123-189$ & 3 & 1 & .02 & 1.12 & 1.90 & 3.48 & 3.05 & 3.36 & 106.6 & 108.9 & .00 & .04 & -.04 & -9.61 \\
\hline $123-189$ & 5 & 1 & .01 & .57 & 1.85 & 3.15 & 2.35 & 2.65 & 102.2 & 102.5 & 1.05 & .68 & .36 & 5.33 \\
\hline $123-189$ & 6 & 1 & .01 & .66 & 1.85 & 3.12 & 2.35 & 2.71 & 102.2 & 103.0 & 1.05 & .67 & .38 & 5.70 \\
\hline $123-189$ & 7 & 1 & .01 & .37 & 1.85 & 2.96 & 2.35 & 2.59 & 102.2 & 101.6 & 1.05 & .67 & .37 & 5.55 \\
\hline $123-189$ & 9 & 1 & .01 & .50 & 1.84 & 3.02 & 2.40 & 2.78 & 102.2 & 101.1 & 2.62 & 1.75 & .87 & 4.96 \\
\hline $123-189$ & 10 & 1 & .01 & .46 & 1.84 & 3.03 & 2.40 & 2.73 & 102.2 & 102.1 & 2.62 & 1.75 & .87 & 4.98 \\
\hline $123-189$ & 11 & 1 & .01 & .42 & 1.84 & 2.99 & 2.40 & 2.70 & 102.2 & 101.7 & 2.62 & 1.73 & .89 & 5.10 \\
\hline $123-189$ & 13 & 1 & .01 & .62 & 1.92 & 3.20 & 2.33 & 2.70 & 105.1 & 107.7 & 5.42 & 3.86 & 1.55 & 4.02 \\
\hline $123-189$ & 14 & 1 & .01 & .92 & 1.92 & 3.39 & 2.33 & 2.67 & 105.1 & 108.0 & 5.42 & 3.82 & 1.60 & 4.18 \\
\hline $123-189$ & 15 & 1 & .01 & 2.31 & 1.92 & 4.15 & 2.33 & 2.65 & .105 .1 & 107.9 & 5.42 & 3.88 & 1.54 & 3.96 \\
\hline $123-189$ & 4 & 2 & .00 & .02 & 1.86 & 1.90 & 3.02 & 3.05 & 105.2 & 106.6 & .00 & .00 & .00 & \\
\hline $123-189$ & 8 & 2 & .01 & .01 & 1.69 & 1.85 & 2.35 & 2.35 & 92.0 & 102.2 & .92 & 1.05 & -.12 & \\
\hline $123-189$ & 12 & 2 & .01 & .01 & 1.84 & 1.84 & 2.44 & 2.40 & 99.5 & 102.2 & 2.50 & 2.62 & -.12 & \\
\hline $123-189$ & 16 & 2 & .01 & .01 & 1.75 & 1.92 & 2.34 & 2.33 & 99.9 & 105.1 & 5.01 & 5.42 & -.41 & \\
\hline $123-189$ & 17 & 3 & -.01 & .00 & .00 & .01 & .12 & .10 & -.8 & 1.4 & .00 & .00 & .00 & \\
\hline
\end{tabular}


Table 6. Basalt mass; initial and final aluminum, calcium, iron, magnesium, potassium, sodium, and strontium concentrations; initial and final specific conductance and $\mathrm{pH}$; and measured distribution coefficients of synthesized solutions - Continued

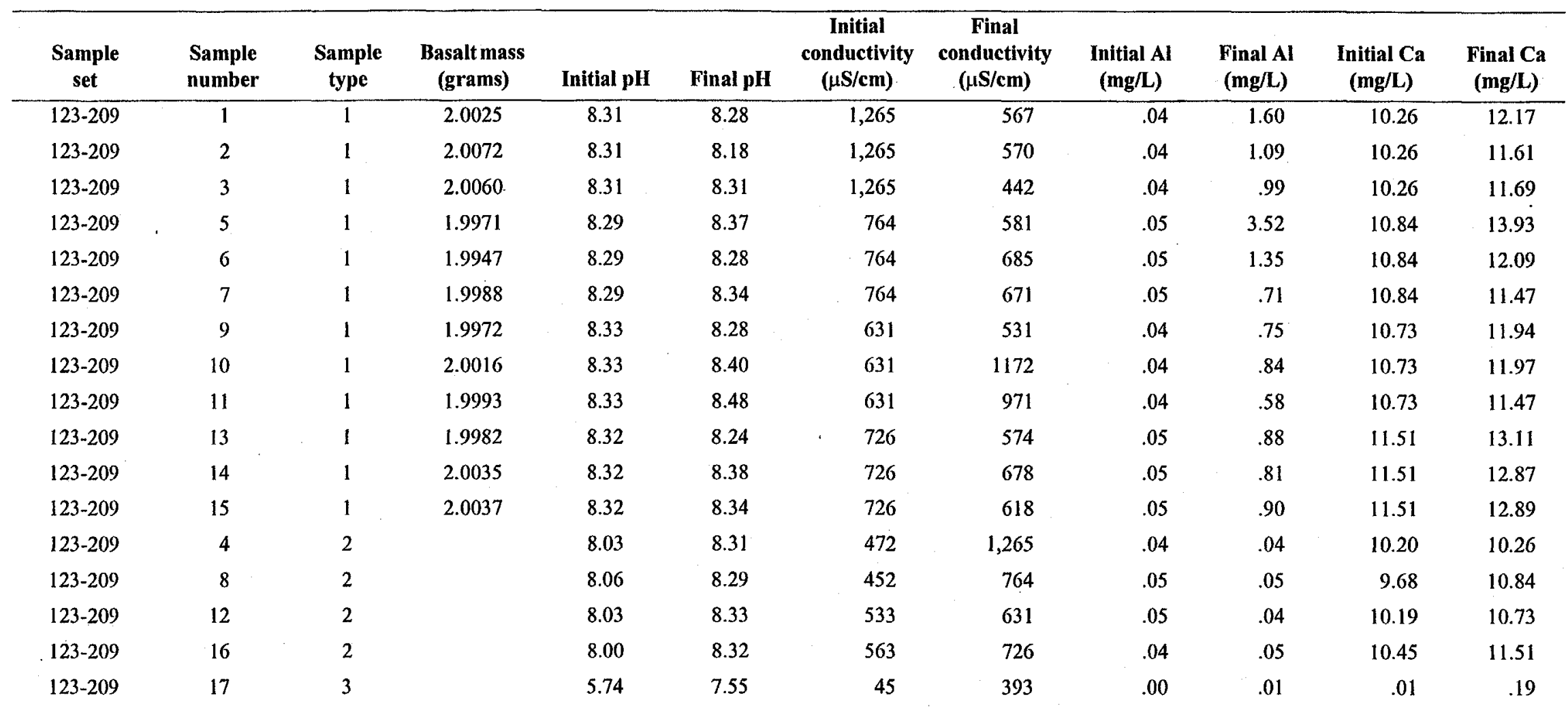


Table 6. Basalt mass; initial and final aluminum, calcium, iron, magnesium, potassium, sodium, and strontium concentrations; initial and final specific conductance and $\mathrm{pH}$; and measured distribution coefficients of synthesized solutions - Continued

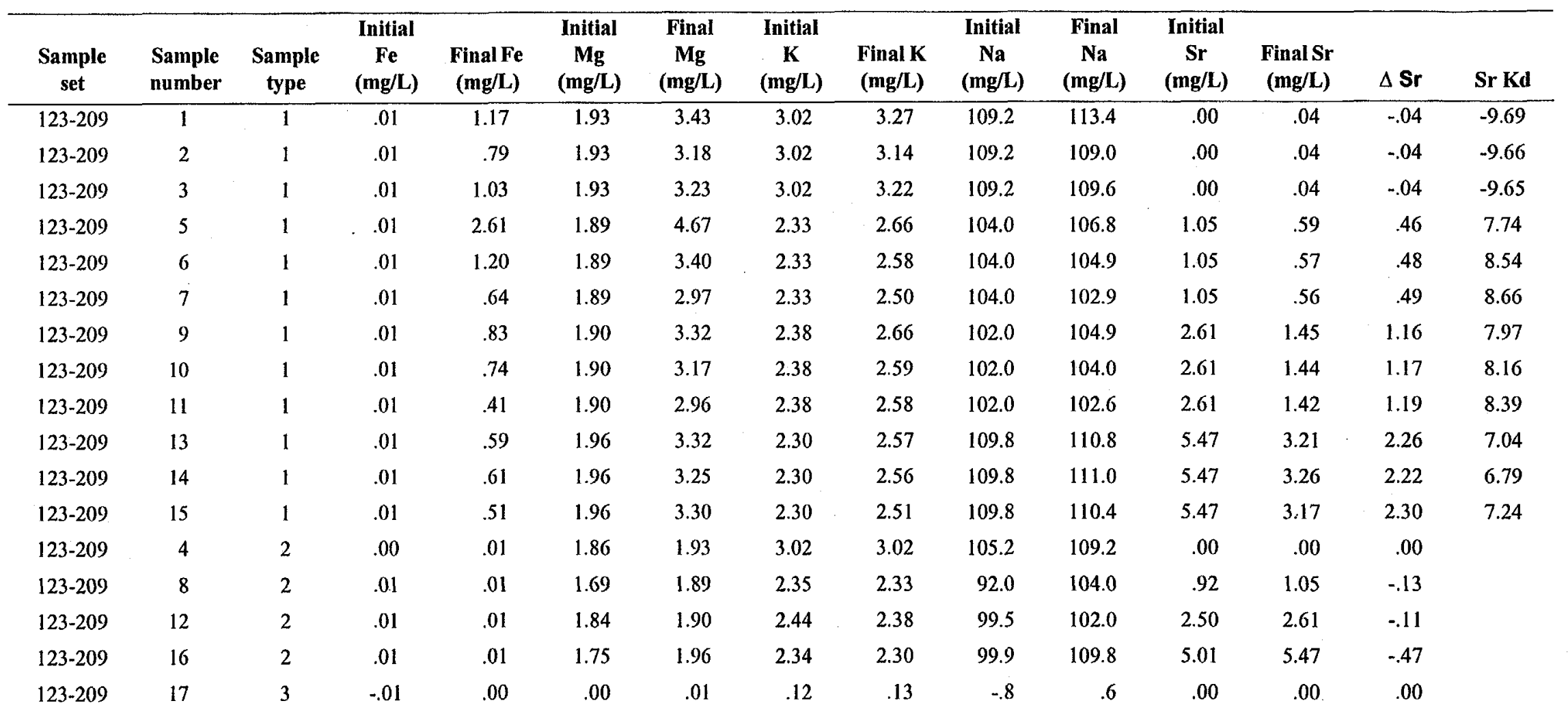


Table 6. Basalt mass; initial and final aluminum, calcium, iron, magnesium, potassium, sodium, and strontium concentrations; initial and final specific conductance and $\mathrm{pH}$; and measured distribution coefficients of synthesized solutions - Continued

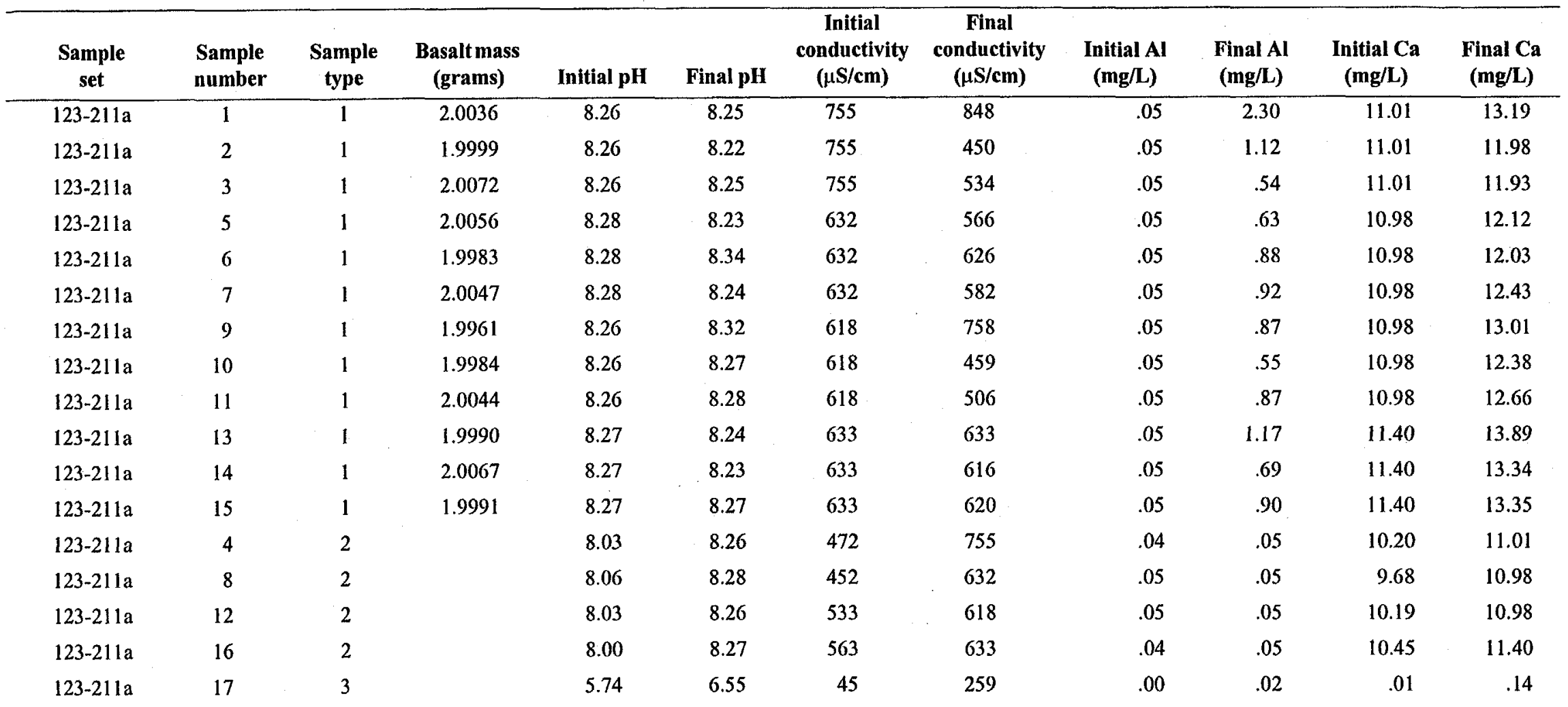


Table 6. Basalt mass; initial and final aluminum, calcium, iron, magnesium, potassium, sodium, and strontium concentrations; initial and final specific conductance and $\mathrm{pH}$; and measured distribution coefficients of synthesized solutions - Continued

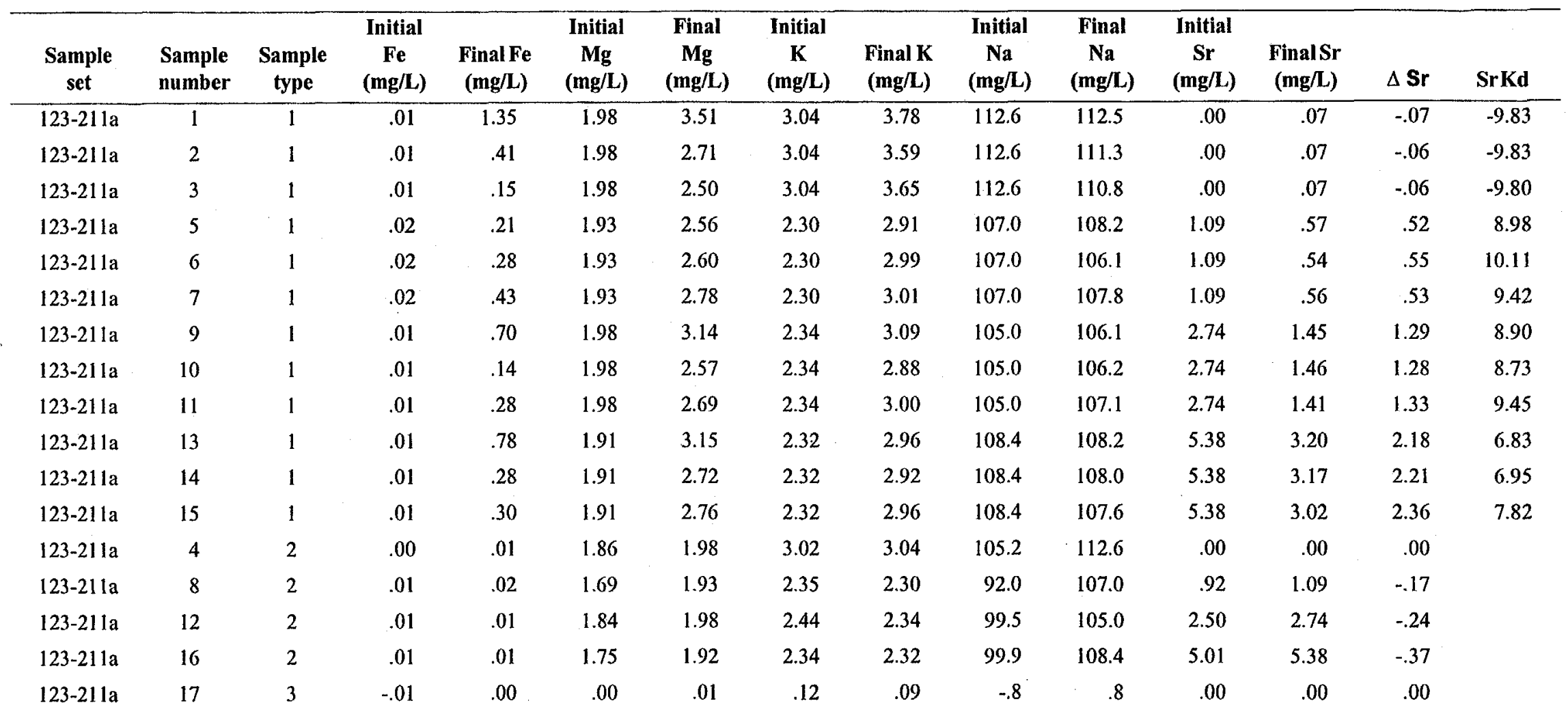


Table 6. Basalt mass; initial and final aluminum, calcium, iron, magnesium, potassium, sodium, and strontium concentrations; initial and final specific conductance and $\mathrm{pH}$; and measured distribution coefficients of synthesized solutions - Continued

\begin{tabular}{|c|c|c|c|c|c|c|c|c|c|c|c|}
\hline $\begin{array}{l}\text { Sample } \\
\text { set }\end{array}$ & $\begin{array}{l}\text { Sample } \\
\text { number }\end{array}$ & $\begin{array}{c}\text { Sample } \\
\text { type }\end{array}$ & $\begin{array}{c}\text { Basalt } \\
\text { mass } \\
\text { (grams) }\end{array}$ & Initial pH & Final pH & $\begin{array}{c}\text { Initial } \\
\text { conductivity } \\
(\mu \mathrm{S} / \mathrm{cm})\end{array}$ & $\begin{array}{c}\text { Final } \\
\text { conductivity } \\
(\mu \mathrm{S} / \mathrm{cm})\end{array}$ & $\begin{array}{c}\text { Initial Al } \\
(\mathbf{m g} / \mathrm{L})\end{array}$ & $\begin{array}{c}\text { Final Al } \\
(\mathrm{mg} / \mathrm{L})\end{array}$ & $\begin{array}{c}\text { Initial Ca } \\
\text { (mg/L) }\end{array}$ & $\begin{array}{c}\text { Final Ca } \\
(\mathrm{mg} / \mathrm{L})\end{array}$ \\
\hline$\overline{123-211 b}$ & 1 & 1 & 1.9970 & 8.11 & 8.30 & 549 & 451 & .04 & 5.73 & 10.05 & 17.25 \\
\hline $123-211 \mathrm{~b}$ & 3 & 1 & 1.9954 & 8.11 & 8.48 & 549 & 786 & .04 & 1.97 & 10.05 & 14.23 \\
\hline $123-211 \mathrm{~b}$ & 5 & 1 & 2.0028 & 8.06 & 8.30 & 613 & 798 & .05 & 2.03 & 10.60 & 15.35 \\
\hline $123-211 b$ & 6 & 1 & 2.0009 & 8.06 & 8.35 & 613 & 634 & .05 & 3.81 & 10.60 & 15.86 \\
\hline $123-211 \mathrm{~b}$ & 9 & 1 & 1.9991 & 8.27 & 8.27 & 549 & 645 & .05 & 1.10 & 10.74 & 14.79 \\
\hline $123-211 \mathrm{~b}$ & 10 & 1 & 2.0045 & 8.27 & 8.26 & 549 & 549 & .05 & 1.56 & 10.74 & 15.51 \\
\hline $123-21 \mathrm{lb}$ & 11 & 1 & 2.0058 & 8.27 & 8.29 & 549 & 502 & .05 & 1.69 & 10.74 & 14.66 \\
\hline $123-211 \mathrm{~b}$ & 13 & 1 & 1.9918 & 8.22 & 8.46 & 735 & 689 & .04 & 2.32 & 11.11 & 16.21 \\
\hline $123-211 b$ & 14 & 1 & 1.9996 & 8.22 & 8.36 & 735 & 535 & .04 & 1.62 & 11.11 & 14.84 \\
\hline $123-21 \mathrm{lb}$ & 15 & 1 & 1.9991 & 8.22 & 8.24 & 735 & 580 & .04 & 1.84 & 11.11 & 15.65 \\
\hline $123-211 \mathrm{~b}$ & 16 & 2 & & 8.03 & 8.22 & 573 & 735 & .05 & .04 & 11.86 & 11.11 \\
\hline $123-211 \mathrm{~b}$ & 17 & 3 & & 4.63 & 6.93 & 35 & 168 & .00 & .04 & .01 & .14 \\
\hline
\end{tabular}


Table 6. Basalt mass; initial and final aluminum, calcium, iron, magnesium, potassium, sodium, and strontium concentrations; initial and final specific conductance and $\mathrm{pH}$; and measured distribution coefficients of synthesized solutions - Continued

\begin{tabular}{|c|c|c|c|c|c|c|c|c|c|c|c|c|c|c|}
\hline $\begin{array}{c}\text { Sample } \\
\text { set }\end{array}$ & $\begin{array}{l}\text { Sample } \\
\text { number }\end{array}$ & $\begin{array}{c}\text { Sample } \\
\text { type }\end{array}$ & $\begin{array}{c}\text { Initial } \\
\text { Fe } \\
(\mathbf{m g} / \mathbf{L})\end{array}$ & $\begin{array}{c}\text { Final Fe } \\
(\mathbf{m g} / \mathbf{L})\end{array}$ & $\begin{array}{c}\text { Initial } \\
\mathbf{M g} \\
(\mathrm{mg} / \mathrm{L})\end{array}$ & $\begin{array}{c}\text { Final } \\
\text { Mg } \\
(\mathrm{mg} / \mathrm{L})\end{array}$ & $\begin{array}{c}\text { Initial } \\
\mathbf{K} \\
(\mathbf{m g} / \mathbf{L})\end{array}$ & $\begin{array}{c}\text { Final K } \\
(\mathrm{mg} / \mathrm{L})\end{array}$ & $\begin{array}{c}\text { Initial } \\
\mathrm{Na} \\
(\mathrm{mg} / \mathrm{L})\end{array}$ & $\begin{array}{c}\text { Final } \\
\mathrm{Na} \\
(\mathbf{m g} / \mathrm{L})\end{array}$ & $\begin{array}{c}\text { Initial } \\
\mathbf{S r} \\
(\mathbf{m g} / \mathrm{L})\end{array}$ & $\begin{array}{c}\text { Final Sr } \\
(\mathrm{mg} / \mathrm{L})\end{array}$ & $\Delta \mathrm{Sr}$ & SrKd \\
\hline $123-211 \mathrm{~b}$ & 1 & 1 & .01 & 4.96 & 1.84 & 6.61 & 3.63 & 4.18 & 106.8 & 106.8 & .00 & .09 & -.09 & -9.87 \\
\hline $123-211 \mathrm{~b}$ & 2 & 1 & .01 & 2.05 & 1.84 & 4.01 & 3.63 & 4.13 & 106.8 & 105.1 & .00 & .08 & -.08 & -9.86 \\
\hline $123-211 \mathrm{~b}$ & 3 & 1 & .01 & 1.04 & 1.84 & 3.34 & 3.63 & 4.08 & 106.8 & 107.6 & .00 & .08 & -.07 & -9.84 \\
\hline $123-211 \mathrm{~b}$ & 5 & 1 & .01 & 2.09 & 1.86 & 4.41 & 2.51 & 3.15 & 101.4 & 106.4 & 1.05 & .59 & .46 & 7.86 \\
\hline $123-211 \mathrm{~b}$ & 6 & 1 & .01 & 2.22 & 1.86 & 4.32 & 2.51 & 3.18 & 101.4 & 100.5 & 1.05 & .56 & .48 & 8.58 \\
\hline $123-211 b$ & 7 & 1 & .01 & 1.40 & 1.86 & 3.60 & 2.51 & 3.13 & 101.4 & 100.0 & 1.05 & .56 & .49 & 8.65 \\
\hline $123-211 b$ & 9 & 1 & $: 01$ & .40 & 1.89 & 2.94 & 2.50 & 3.21 & 105.4 & 108.0 & 2.69 & 1.47 & 1.22 & 8.35 \\
\hline $123-211 \mathrm{~b}$ & 10 & 1 & .01 & .88 & 1.89 & 3.37 & 2.50 & 3.15 & 105.4 & 107.2 & 2.69 & 1.49 & 1.20 & 8.07 \\
\hline $123-211 \mathrm{~b}$ & 11 & 1 & .01 & 1.27 & 1.89 & 3.65 & 2.50 & 3.10 & 105.4 & 106.3 & 2.69 & 1.45 & 1.24 & 8.56 \\
\hline $123-211 b$ & 13 & 1 & .01 & 1.03 & 1.84 & 3.32 & 2.40 & 3.07 & 103.8 & 106.3 & 5.40 & 3.10 & 2.31 & 7.48 \\
\hline $123-211 b$ & 14 & 1 & .01 & .91 & 1.84 & 3.24 & 2.40 & 3.13 & 103.8 & 106.8 & 5.40 & 3.06 & 2.34 & 7.67 \\
\hline $123-211 \mathrm{~b}$ & 15 & 1 & .01 & 5.74 & 1.84 & 7.51 & 2.40 & 2.99 & 103.8 & 104.7 & 5.40 & 3.13 & 2.27 & 7.26 \\
\hline $123-211 b$ & 4 & 2 & .01 & .01 & 2.06 & 1.84 & 3.63 & 3.63 & 112.1 & 106.8 & .00 & .00 & .00 & \\
\hline $123-211 \mathrm{~b}$ & 8 & 2 & .00 & .01 & 2.02 & 1.86 & 2.49 & 2.51 & 106.4 & 101.4 & 1.13 & 1.05 & .08 & \\
\hline $123-211 b$ & 12 & 2 & .00 & .01 & 2.02 & 1.89 & 2.58 & 2.50 & 106.1 & 105.4 & 2.80 & 2.69 & .11 & \\
\hline $123-211 b$ & 16 & 2 & .00 & .01 & 2.03 & 1.84 & 2.52 & 2.40 & 109.6 & 103.8 & 5.73 & 5.40 & .33 & \\
\hline $123-211 b$ & 17 & 3 & -.01 & .01 & .00 & .01 & .13 & .11 & -.8 & .4 & .00 & .00 & .00 & \\
\hline
\end{tabular}


Table 6. Basalt mass; initial and final aluminum, calcium, iron, magnesium, potassium, sodium, and strontium concentrations; initial and final specific conductance and $\mathrm{pH}$; and measured distribution coefficients of synthesized solutions - Continued

\begin{tabular}{|c|c|c|c|c|c|c|c|c|c|c|c|}
\hline $\begin{array}{l}\text { Sample } \\
\text { set }\end{array}$ & $\begin{array}{l}\text { Sample } \\
\text { number }\end{array}$ & $\begin{array}{c}\text { Sample } \\
\text { type }\end{array}$ & $\begin{array}{c}\text { Basalt } \\
\text { mass } \\
\text { (grams) }\end{array}$ & Initial pH & Final pH & $\begin{array}{c}\text { Initial } \\
\text { conductivity } \\
(\mu \mathrm{S} / \mathrm{cm})\end{array}$ & $\begin{array}{c}\text { Final } \\
\text { conductivity } \\
(\mu \mathrm{S} / \mathrm{cm})\end{array}$ & $\begin{array}{c}\text { Initial Al } \\
(\mathrm{mg} / \mathrm{L})\end{array}$ & $\begin{array}{c}\text { Final Al } \\
(\mathbf{m g} / \mathbf{L})\end{array}$ & $\begin{array}{c}\text { Initial Ca } \\
\text { (mg/L) }\end{array}$ & $\begin{array}{c}\text { Final Ca } \\
(\mathrm{mg} / \mathrm{L})\end{array}$ \\
\hline $123-221$ & 1 & 1 & 1.9985 & 8.20 & 8.25 & 636 & 593 & .04 & 1.81 & 10.12 & 12.33 \\
\hline $123-221$ & 3 & 1 & 2.0054 & 8.20 & 8.24 & 636 & 529 & .04 & 1.91 & 10.12 & 12.54 \\
\hline $123-221$ & 5 & 1 & 2.0007 & 8.23 & 8.27 & 421 & 527 & .04 & 1.57 & 10.61 & 12.87 \\
\hline $123-221$ & 6 & 1 & 2.0073 & 8.23 & 8.26 & 421 & 340 & .04 & 1.33 & 10.61 & 12.51 \\
\hline $123-221$ & 9 & 1 & 2.0090 & 8.24 & 8.29 & 601 & 612 & .04 & 1.30 & 10.69 & 12.77 \\
\hline $123-221$ & 10 & 1 & 1.9967 & 8.24 & 8.41 & 601 & 717 & .04 & 1.24 & 10.69 & 12.37 \\
\hline $123-221$ & 11 & 1 & 2.0020 & 8.24 & 8.28 & 601 & 439 & .04 & 2.38 & 10.69 & 13.79 \\
\hline $123-221$ & 13 & 1 & 2.0050 & 8.26 & 8.26 & 683 & 680 & .05 & 1.22 & 11.41 & 13.66 \\
\hline $123-221$ & 14 & 1 & 1.9964 & 8.26 & 8.37 & 683 & 458 & .05 & 1.22 & 11.41 & 13.68 \\
\hline $123-221$ & 15 & 1 & 1.9998 & 8.26 & 8.31 & 683 & 697 & .05 & .96 & 11.41 & 13.52 \\
\hline $123-221$ & 16 & 2 & & 8.00 & 8.26 & 563 & 683 & .04 & .04 & 10.45 & 11.41 \\
\hline $123-221$ & 17 & 3 & & 5.74 & 6.33 & 45 & 279 & .00 & .01 & .01 & .17 \\
\hline
\end{tabular}


Table 6. Basalt mass; initial and final aluminum, calcium, iron, magnesium, potassium, sodium, and strontium concentrations; initial and final specific conductance and $\mathrm{pH}$; and measured distribution coefficients of synthesized solutions - Continued

\begin{tabular}{|c|c|c|c|c|c|c|c|c|c|c|c|c|c|c|}
\hline $\begin{array}{c}\text { Sample } \\
\text { set }\end{array}$ & $\begin{array}{l}\text { Sample } \\
\text { number }\end{array}$ & $\begin{array}{c}\text { Sample } \\
\text { type }\end{array}$ & $\begin{array}{c}\text { Initial } \\
\mathbf{F e} \\
(\mathrm{mg} / \mathrm{L})\end{array}$ & $\begin{array}{c}\text { Final Fe } \\
(\mathrm{mg} / \mathbf{L})\end{array}$ & $\begin{array}{c}\text { Initial } \\
\text { Mg } \\
(\mathbf{m g} / \mathbf{L})\end{array}$ & $\begin{array}{c}\text { Final } \\
\text { Mg } \\
(\mathbf{m g} / \mathbf{L})\end{array}$ & $\begin{array}{c}\text { Initial K } \\
(\mathrm{mg} / \mathrm{L})\end{array}$ & $\begin{array}{c}\text { Final K } \\
(\mathrm{mg} / \mathrm{L})\end{array}$ & $\begin{array}{c}\text { Initial } \\
\mathrm{Na} \\
(\mathrm{mg} / \mathrm{L})\end{array}$ & $\begin{array}{c}\text { Final } \\
\mathrm{Na} \\
(\mathrm{mg} / \mathrm{L})\end{array}$ & $\begin{array}{c}\text { Initial } \\
\mathbf{S r} \\
(\mathbf{m g} / \mathrm{L})\end{array}$ & $\begin{array}{c}\text { Final Sr } \\
(\mathrm{mg} / \mathrm{L})\end{array}$ & $\Delta \mathbf{S r}$ & Sr Kd \\
\hline $123-221$ & 1 & 1 & .00 & .74 & 1.96 & 2.98 & 3.12 & 4.05 & 109.4 & 107.7 & .00 & .10 & -.10 & -9.89 \\
\hline $123-221$ & 2 & 1 & .00 & .74 & 1.96 & 2.97 & 3.12 & 3.88 & 109.4 & 109.4 & .00 & .10 & -.10 & -9.85 \\
\hline $123-221$ & 3 & 1 & .00 & .72 & 1.96 & 2.99 & 3.12 & 3.91 & 109.4 & 106.0 & .00 & .10 & -.10 & -9.86 \\
\hline $123-221$ & 5 & 1 & .00 & 1.00 & 1.90 & 3.23 & 2.35 & 3.29 & 104.8 & 104.7 & 1.06 & .47 & .59 & 12.41 \\
\hline $123-221$ & 6 & 1 & .00 & .46 & 1.90 & 2.85 & 2.35 & 3.22 & 104.8 & 105.4 & 1.06 & .46 & .60 & 13.03 \\
\hline $123-221$ & 7 & 1 & .00 & .68 & 1.90 & 2.94 & 2.35 & 3.31 & 104.8 & 102.3 & 1.06 & .45 & .61 & 13.51 \\
\hline $123-221$ & 9 & 1 & .01 & .44 & 1.85 & 2.96 & 2.33 & 3.31 & 103.0 & 103.5 & 2.63 & 1.10 & 1.53 & 13.79 \\
\hline $123-221$ & 10 & 1 & .01 & .39 & 1.85 & 2.68 & 2.33 & 3.30 & 103.0 & 102.7 & 2.63 & 1.08 & 1.56 & 14.47 \\
\hline $123-221$ & 11 & 1 & .01 & 1.44 & 1.85 & 3.68 & 2.33 & 3.40 & 103.0 & 101.5 & 2.63 & 1.09 & 1.55 & 14.19 \\
\hline $123-221$ & 13 & 1 & .01 & .45 & 1.91 & 2.99 & 2.29 & 3.31 & 104.4 & 104.1 & 5.32 & 2.46 & 2.86 & 11.58 \\
\hline $123-221$ & 14 & 1 & .01 & .48 & 1.91 & 2.90 & 2.29 & 3.29 & 104.4 & 106.2 & 5.32 & 2.42 & 2.90 & 11.97 \\
\hline $123-221$ & 15 & 1 & .01 & .43 & 1.91 & 2.90 & 2.29 & 3.24 & 104.4 & 105.2 & 5.32 & 2.46 & 2.86 & 11.65 \\
\hline $123-221$ & 4 & 2 & .00 & .00 & 1.86 & 1.96 & 3.02 & 3.12 & 105.2 & 109.4 & .00 & .00 & .00 & \\
\hline $123-221$ & 8 & 2 & .01 & .00 & 1.69 & 1.90 & 2.35 & 2.35 & 92.0 & 104.8 & .92 & 1.06 & -.14 & \\
\hline $123-221$ & 12 & 2 & .01 & .01 & 1.84 & 1.85 & 2.44 & 2.33 & 99.5 & 103.0 & 2.50 & 2.63 & -.13 & \\
\hline $123-221$ & 16 & 2 & .01 & .01 & 1.75 & 1.91 & 2.34 & 2.29 & 99.9 & 104.4 & 5.01 & 5.32 & -.31 & \\
\hline $123-221$ & 17 & 3 & -.01 & .00 & .00 & .00 & .12 & .06 & -.8 & .8 & .00 & .00 & .00 & \\
\hline
\end{tabular}


Table 6. Basalt mass; initial and final aluminum, calcium, iron, magnesium, potassium, sodium, and strontium concentrations; initial and final specific conductance and $\mathrm{pH}$; and measured distribution coefficients of synthesized solutions - Continued

\begin{tabular}{|c|c|c|c|c|c|c|c|c|c|c|c|}
\hline $\begin{array}{l}\text { Sample } \\
\text { set }\end{array}$ & $\begin{array}{l}\text { Sample } \\
\text { number }\end{array}$ & $\begin{array}{c}\text { Sample } \\
\text { type }\end{array}$ & $\begin{array}{c}\text { Basalt } \\
\text { mass } \\
\text { (grams) }\end{array}$ & Initial pH & Final pH & $\begin{array}{c}\text { Initial } \\
\text { conductivity } \\
(\mu \mathrm{S} / \mathrm{cm})\end{array}$ & $\begin{array}{c}\text { Final } \\
\text { conductivity } \\
(\mu \mathrm{S} / \mathrm{cm})\end{array}$ & $\begin{array}{c}\text { Initial Al } \\
\text { (mg/L) }\end{array}$ & $\begin{array}{c}\text { Final Al } \\
(\mathrm{mg} / \mathrm{L})\end{array}$ & $\begin{array}{c}\text { Initial Ca } \\
(\mathrm{mg} / \mathrm{L})\end{array}$ & $\begin{array}{c}\text { Final Ca } \\
(\mathrm{mg} / \mathrm{L})\end{array}$ \\
\hline WO-1-141 & 1 & 1 & 1.9990 & 8.10 & 8.08 & 747 & 675 & .04 & 2.03 & 10.26 & $\overline{13.56}$ \\
\hline WO-1-141 & 3 & 1 & 2.0086 & 8.10 & 8.09 & 747 & 694 & .04 & 1.48 & 10.26 & 12.64 \\
\hline WO-1-141 & 5 & 1 & 2.0000 & 8.15 & 8.09 & 657 & 692 & .04 & 1.80 & 10.76 & 13.26 \\
\hline WO-1-141 & 6 & 1 & 2.0057 & 8.15 & 8.15 & 657 & 588 & .04 & 1.34 & 10.76 & 12.78 \\
\hline WO-1-141 & 9 & 1 & 1.9999 & 8.14 & 8.07 & 545 & 588 & .04 & 2.30 & 10.46 & 15.37 \\
\hline WO-1-141 & 10 & 1 & 1.9985 & 8.14 & 8.08 & 545 & 681 & .04 & 1.01 & 10.46 & 13.83 \\
\hline WO-1-141 & 11 & 1 & 1.9936 & 8.14 & 8.11 & 545 & 819 & .04 & 1.13 & 10.46 & 13.12 \\
\hline WO-1-141 & 13 & 1 & 2.0042 & 8.09 & 8.01 & 577 & 607 & .04 & 0.36 & 11.13 & 14.42 \\
\hline WO-1-141 & 14 & 1 & 2.0015 & 8.09 & 8.03 & 577 & 530 & .04 & 0.74 & 11.13 & 14.42 \\
\hline WO-1-141 & 15 & 1 & 1.9961 & 8.09 & 8.38 & 577 & 859 & .04 & .72 & 11.13 & 13.95 \\
\hline WO-1-141 & 16 & 2 & & 8.03 & 8.09 & 573 & 577 & .05 & .40 & 11.86 & 11.13 \\
\hline WO-1-141 & 17 & 3 & & 4.63 & 8.01 & 35 & 109 & .00 & .01 & .01 & .18 \\
\hline
\end{tabular}


Table 6. Basalt mass; initial and final aluminum, calcium, iron, magnesium, potassium, sodium, and strontium concentrations; initial and final specific conductance and $\mathrm{pH}$; and measured distribution coefficients of synthesized solutions - Continued

\begin{tabular}{|c|c|c|c|c|c|c|c|c|c|c|c|c|c|c|}
\hline $\begin{array}{l}\text { Sample } \\
\text { set }\end{array}$ & $\begin{array}{l}\text { Sample } \\
\text { number }\end{array}$ & $\begin{array}{c}\text { Sample } \\
\text { type }\end{array}$ & $\begin{array}{c}\text { Initial } \\
\mathbf{F e} \\
(\mathrm{mg} / \mathrm{L})\end{array}$ & $\begin{array}{c}\text { Final Fe } \\
(\mathrm{mg} / \mathrm{L})\end{array}$ & $\begin{array}{c}\text { Initial } \\
\mathbf{M g} \\
(\mathbf{m g} / \mathbf{L})\end{array}$ & $\begin{array}{c}\text { Final } \\
\text { Mg } \\
(\mathrm{mg} / \mathrm{L})\end{array}$ & $\begin{array}{c}\text { Initial K } \\
(\mathrm{mg} / \mathrm{L})\end{array}$ & $\begin{array}{c}\text { Final K } \\
(\mathrm{mg} / \mathrm{L})\end{array}$ & $\begin{array}{c}\text { Initial } \\
\mathrm{Na} \\
(\mathrm{mg} / \mathrm{L})\end{array}$ & $\begin{array}{c}\text { Final } \\
\mathrm{Na} \\
(\mathrm{mg} / \mathrm{L})\end{array}$ & $\begin{array}{c}\text { Initial Sr } \\
(\mathbf{m g} / \mathrm{L})\end{array}$ & $\begin{array}{c}\text { Final Sr } \\
(\mathrm{mg} / \mathrm{L})\end{array}$ & $\Delta \mathrm{Sr}$ & Sr Kd \\
\hline WO-1-141 & 1 & 1 & .01 & 1.50 & 1.93 & 3.09 & 3.50 & 4.23 & 106.1 & 107.0 & .00 & .10 & -.09 & -9.85 \\
\hline WO-1-141 & 3 & 1 & .01 & .81 & 1.93 & 2.71 & 3.50 & 4.06 & 106.1 & 103.2 & .00 & .09 & -.09 & -9.79 \\
\hline WO-1-141 & 5 & 1 & .00 & 1.07 & 1.85 & 2.82 & 2.46 & 3.41 & 101.3 & 101.1 & 1.03 & .35 & .68 & 19.69 \\
\hline WO-1-141 & 6 & 1 & .00 & .77 & 1.85 & 2.70 & 2.46 & 3.40 & 101.3 & 99.4 & 1.03 & .34 & .69 & 20.24 \\
\hline WO-1-141 & 9 & 1 & .01 & 5.93 & 1.81 & 4.93 & 2.42 & 3.55 & 99.3 & 98.2 & 2.53 & .79 & 1.75 & 22.14 \\
\hline WO-1-141 & 10 & 1 & .01 & 3.92 & 1.81 & 4.39 & 2.42 & 3.33 & 99.3 & 97.9 & 2.53 & .78 & 1.76 & 22.68 \\
\hline WO-1-14l & 11 & 1 & .01 & 1.12 & 1.81 & 2.94 & 2.42 & 3.48 & 99.3 & 95.6 & 2.53 & .75 & 1.78 & 23.65 \\
\hline WO-1-141 & 13 & 1 & .01 & .22 & 1.80 & 2.90 & 2.34 & 3.39 & 101.5 & 101.8 & 5.25 & 1.69 & 3.55 & 20.96 \\
\hline WO-1-141 & 14 & 1 & .01 & .52 & 1.80 & 2.94 & 2.34 & 3.51 & 101.5 & 101.2 & 5.25 & 1.65 & 3.60 & 21.82 \\
\hline WO-1-141 & 15 & 1 & .01 & .45 & 1.80 & 2.77 & 2.34 & 3.47 & 101.5 & 99.9 & 5.25 & 1.60 & 3.65 & 22.88 \\
\hline WO-1-14I & 16 & 2 & .00 & .01 & 2.03 & 1.80 & 2.52 & 2.34 & 109.6 & 101.5 & 5.73 & 5.25 & .48 & \\
\hline WO-1-141 & 17 & 3 & -.01 & .00 & .00 & .01 & .13 & .11 & -.8 & -.1 & .00 & .00 & .00 & \\
\hline
\end{tabular}


Table 6. Basalt mass; initial and final aluminum, calcium, iron, magnesium, potassium, sodium, and strontium concentrations; initial and final specific conductance and $\mathrm{pH}$; and measured distribution coefficients of synthesized solutions - Continued

\begin{tabular}{|c|c|c|c|c|c|c|c|c|c|c|c|}
\hline $\begin{array}{l}\text { Sample } \\
\text { set }\end{array}$ & $\begin{array}{l}\text { Sample } \\
\text { number }\end{array}$ & $\begin{array}{c}\text { Sample } \\
\text { type }\end{array}$ & $\begin{array}{c}\text { Basalt mass } \\
\text { (grams) }\end{array}$ & Initial pH & Final pH & $\begin{array}{c}\text { Initial } \\
\text { conductivity } \\
(\mu \mathrm{S} / \mathrm{cm})\end{array}$ & $\begin{array}{c}\text { Final } \\
\text { conductivity } \\
(\mu \mathrm{S} / \mathrm{cm})\end{array}$ & $\begin{array}{c}\text { Initial AI } \\
\text { (mg/L) }\end{array}$ & $\begin{array}{c}\text { Final Al } \\
(\mathrm{mg} / \mathrm{L})\end{array}$ & $\begin{array}{c}\text { Initial } \mathbf{C a} \\
\text { (mg/L) }\end{array}$ & $\begin{array}{c}\text { Final Ca } \\
(\mathrm{mg} / \mathrm{L})\end{array}$ \\
\hline WO-1-146 & 1 & 1 & 2.0014 & 8.14 & 8.29 & 899 & 690 & .04 & 1.57 & 10.31 & 12.45 \\
\hline WO-1-146 & 3 & 1 & 2.0013 & 8.14 & 8.25 & 899 & 581 & .04 & 1.28 & 10.31 & 12.34 \\
\hline WO-1-146 & 5 & 1 & 1.9984 & 8.19 & 8.28 & 594 & 616 & .04 & 1.21 & 10.81 & 13.11 \\
\hline WO-1-146 & 6 & 1 & 1.9929 & 8.19 & 8.27 & 594 & 629 & .04 & 1.16 & 10.81 & 12.79 \\
\hline WO-1-146 & 9 & 1 & 2.0012 & 8.20 & 8.16 & 648 & 587 & .03 & 1.11 & 10.46 & 12.84 \\
\hline Wo-1-146 & 10 & 1 & 1.9919 & 8.20 & 8.16 & 648 & 554 & .03 & 1.07 & 10.46 & 12.74 \\
\hline WO-1-146 & 11 & 1 & 2.0083 & 8.20 & 8.20 & 648 & 1,194 & .03 & 1.37 & 10.46 & 12.88 \\
\hline WO-1-146 & 13 & 1 & 2.0015 & 8.18 & 8.16 & 621 & 585 & .05 & 1.06 & 11.35 & 14.02 \\
\hline WO-1-146 & 14 & 1 & 1.9993 & 8.18 & 8.16 & 621 & 678 & .05 & .89 & 11.35 & 13.74 \\
\hline WO-1-146 & 15 & 1 & 2.0053 & 8.18 & 8.08 & 621 & 605 & .05 & .81 & 11.35 & 13.78 \\
\hline WO-1-146 & 16 & 2 & & 8.03 & 8.18 & 573 & 621 & .05 & .05 & 11.86 & 11.35 \\
\hline WO-1-146 & 17 & 3 & & 4.63 & 6.15 & 35 & 1,103 & .00 & .01 & .01 & .15 \\
\hline
\end{tabular}


Table 6. Basalt mass; initial and final aluminum, calcium, iron, magnesium, potassium, sodium, and strontium concentrations; initial and final specific conductance and $\mathrm{pH}$; and measured distribution coefficients of synthesized solutions - Continued

\begin{tabular}{|c|c|c|c|c|c|c|c|c|c|c|c|c|c|c|}
\hline $\begin{array}{l}\text { Sample } \\
\text { set }\end{array}$ & $\begin{array}{l}\text { Sample } \\
\text { number }\end{array}$ & $\begin{array}{c}\text { Sample } \\
\text { type }\end{array}$ & $\begin{array}{c}\text { Initial } \\
\mathbf{F e} \\
(\mathrm{mg} / \mathrm{L})\end{array}$ & $\begin{array}{c}\text { Final } \\
\text { Fe } \\
(\mathrm{mg} / \mathrm{L})\end{array}$ & $\begin{array}{c}\text { Initial } \\
\mathbf{M g} \\
(\mathrm{mg} / \mathrm{L})\end{array}$ & $\begin{array}{c}\text { Final } \\
\text { Mg } \\
(\mathbf{m g} / \mathbf{L})\end{array}$ & $\begin{array}{c}\text { Initial } \\
\mathbf{K} \\
(\mathbf{m g} / \mathbf{L})\end{array}$ & $\begin{array}{l}\text { Final K } \\
(\mathbf{m g} / \mathbf{L})\end{array}$ & $\begin{array}{c}\text { Initial } \\
\mathrm{Na} \\
(\mathrm{mg} / \mathrm{L})\end{array}$ & $\begin{array}{c}\text { Final } \\
\mathrm{Na} \\
(\mathrm{mg} / \mathrm{L})\end{array}$ & $\begin{array}{c}\text { Initial } \\
\mathrm{Sr} \\
(\mathrm{mg} / \mathrm{L})\end{array}$ & $\begin{array}{c}\text { Final } \\
\mathrm{Sr} \\
(\mathrm{mg} / \mathrm{L})\end{array}$ & $\Delta \mathrm{Sr}$ & Sr Kd \\
\hline WO-1-146 & 1 & 1 & .01 & .60 & 1.91 & 2.59 & 3.48 & 4.12 & 107.7 & 108.8 & .00 & .09 &. .09 & -9.82 \\
\hline WO-1-146 & 3 & 1 & .01 & .90 & 1.91 & 2.66 & 3.48 & 4.07 & 107.7 & 107.2 & .00 & .09 & -.09 & -9.82 \\
\hline WO-1-146 & 5 & 1 & .00 & .92 & 1.85 & 2.84 & 2.43 & 3.30 & 103.7 & 105.3 & 1.06 & .56 & .50 & 8.86 \\
\hline Wo-1-146 & 6 & 1 & .00 & .58 & 1.85 & 2.55 & 2.43 & 3.27 & 103.7 & 101.7 & 1.06 & .54 & .52 & 9.75 \\
\hline WO-1-146 & 9 & 1 & .00 & .55 & 1.83 & 2.54 & 2.51 & 3.38 & 99.5 & 100.2 & 2.57 & 1.33 & 1.24 & 9.36 \\
\hline WO-1-146 & 10 & 1 & .00 & .59 & 1.83 & 2.58 & 2.51 & 3.39 & 99.5 & 99.4 & 2.57 & 1.27 & 1.29 & 10.17 \\
\hline Wo-1-146 & 11 & 1 & .00 & .72 & 1.83 & 2.60 & 2.51 & 3.33 & 99.5 & 99.2 & 2.57 & 1.30 & 1.26 & 9.65 \\
\hline WO-1-146 & 13 & 1 & .00 & .57 & 1.89 & 2.66 & 2.38 & 3.28 & 105.0 & 105.2 & 5.45 & 2.90 & 2.54 & 8.75 \\
\hline WO-I-146 & 14 & 1 & .00 & .42 & 1.89 & 2.57 & 2.38 & 3.26 & 105.0 & 104.4 & 5.45 & 2.85 & 2.60 & 9.10 \\
\hline WO-1-146 & 15 & 1 & .00 & .36 & 1.89 & 2.56 & 2.38 & 3.26 & 105.0 & 103.6 & 5.45 & 2.84 & 2.61 & 9.18 \\
\hline WO-1-146 & 16 & 2 & .00 & .00 & 2.03 & 1.89 & 2.52 & 2.38 & 109.6 & 105.0 & 5.73 & 5.45 & .28 & \\
\hline WO-1-146 & 17 & 3 & -.01 & .00 & .00 & .01 & .13 & .16 & -.8 & .1 & .00 & .00 & .00 & \\
\hline
\end{tabular}


Table 6. Basalt mass; initial and final aluminum, calcium, iron, magnesium, potassium, sodium, and strontium concentrations; initial and final specific conductance and $\mathrm{pH}$; and measured distribution coefficients of synthesized solutions - Continued

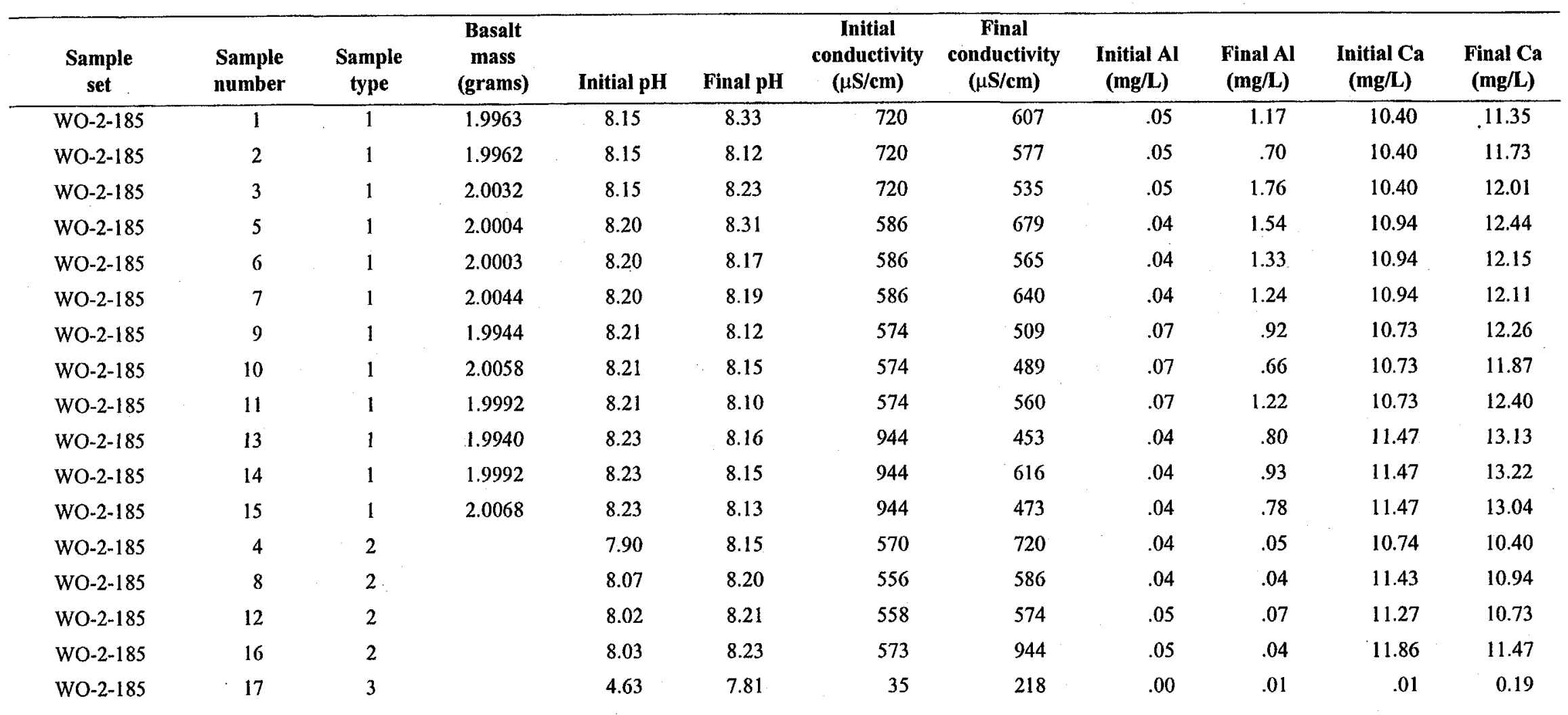


Table 6. Basalt mass; initial and final aluminum, calcium, iron, magnesium, potassium, sodium, and strontium concentrations; initial and final specific conductance and $\mathrm{pH}$; and measured distribution coefficients of synthesized solutions - Continued

\begin{tabular}{|c|c|c|c|c|c|c|c|c|c|c|c|c|c|c|}
\hline $\begin{array}{c}\text { Sample } \\
\text { set }\end{array}$ & $\begin{array}{l}\text { Sample } \\
\text { number }\end{array}$ & $\begin{array}{c}\text { Sample } \\
\text { type }\end{array}$ & $\begin{array}{c}\text { Initial } \\
\mathrm{Fe} \\
\text { (mg/L) }\end{array}$ & $\begin{array}{c}\text { Final } \\
\text { Fe } \\
(\mathrm{mg} / \mathrm{L})\end{array}$ & $\begin{array}{c}\text { Initial } \\
\mathrm{Mg} \\
(\mathrm{mg} / \mathrm{L})\end{array}$ & $\begin{array}{c}\text { Final } \\
\mathrm{Mg} \\
(\mathrm{mg} / \mathrm{L})\end{array}$ & $\begin{array}{c}\text { Initial } \\
\mathrm{K} \\
(\mathrm{mg} / \mathrm{L})\end{array}$ & $\begin{array}{c}\text { Final K } \\
(\mathrm{mg} / \mathrm{L})\end{array}$ & $\begin{array}{c}\text { Initial } \\
\mathrm{Na} \\
(\mathrm{mg} / \mathrm{L})\end{array}$ & $\begin{array}{c}\text { Final } \\
\text { Na } \\
(\mathrm{mg} / \mathrm{L})\end{array}$ & $\begin{array}{c}\text { Initial } \\
\text { Sr } \\
(\mathrm{mg} / \mathrm{L})\end{array}$ & $\begin{array}{c}\text { Final } \\
\text { Sr } \\
\text { (mg/L) }\end{array}$ & $\Delta \mathbf{S r}$ & Sr Kd \\
\hline WO-2-185 & 1 & 1 & .01 & .76 & 1.93 & 2.77 & 3.39 & 4.14 & 109.3 & 113.3 & .00 & .06 & -.06 & -9.74 \\
\hline WO-2-185 & 2 & 1 & .01 & .33 & 1.93 & 2.66 & 3.39 & 4.06 & 109.3 & 109.1 & .00 & .06 & -.06 & -9.74 \\
\hline WO-2-185 & 3 & 1 & .01 & 1.20 & 1.93 & 3.13 & 3.39 & 4.09 & 109.3 & 108.3 & .00 & .06 & -.06 & -9.71 \\
\hline WO-2-185 & 5 & 1 & .01 & 1.42 & 1.87 & 3.30 & 2.29 & 3.17 & 104.0 & 106.5 & 1.07 & .59 & .48 & 8.08 \\
\hline WO-2-185 & 6 & 1 & .01 & .85 & 1.87 & 2.77 & 2.29 & 3.15 & 104.0 & 104.9 & 1.07 & .59 & .48 & 8.14 \\
\hline WO-2-185 & 7 & 1 & .01 & 1.00 & 1.87 & 3.08 & 2.29 & 3.07 & 104.0 & 104.9 & 1.07 & .58 & .49 & 8.33 \\
\hline WO-2-185 & 9 & 1 & .11 & .64 & 1.92 & 2.90 & 2.36 & 3.16 & 104.4 & 103.6 & 2.66 & 1.47 & 1.19 & 8.10 \\
\hline WO-2-185 & 10 & 1 & .11 & .25 & 1.92 & 2.62 & 2.36 & 3.05 & 104.4 & 102.5 & 2.66 & 1.48 & 1.18 & 7.96 \\
\hline WO-2-185 & 11 & 1 & .11 & 1.97 & 1.92 & 3.89 & 2.36 & 3.11 & 104.4 & 102.3 & 2.66 & 1.45 & 1.22 & 8.41 \\
\hline WO-2-185 & 13 & 1 & .01 & .46 & 1.90 & 3.03 & 2.28 & 3.10 & 106.6 & 108.5 & 5.36 & 3.17 & 2.18 & 6.91 \\
\hline WO-2-185 & 14 & 1 & .01 & .44 & 1.90 & 2.92 & 2.28 & 3.06 & 106.6 & 105.6 & 5.36 & 3.20 & 2.16 & 6.77 \\
\hline WO-2-185 & 15 & 1 & .01 & .48 & 1.90 & 2.89 & 2.28 & 3.01 & 106.6 & 103.0 & 5.36 & 3.12 & 2.24 & 7.15 \\
\hline WO-2-185 & 4 & 2 & .01 & .01 & 2.06 & 1.93 & 3.63 & 3.39 & 112.1 & 109.3 & .00 & .00 & .00 & \\
\hline WO-2-185 & 8 & 2 & .00 & .01 & 2.02 & 1.87 & 2.49 & 2.29 & 106.4 & 104.0 & 1.13 & 1.07 & .06 & \\
\hline WO-2-185 & 12 & 2 & .00 & .11 & 2.02 & 1.92 & 2.59 & 2.36 & 106.1 & 104.4 & 2.80 & 2.66 & .14 & \\
\hline WO-2-185 & 16 & 2 & .00 & .01 & 2.03 & 1.90 & 2.52 & 2.28 & 109.6 & 106.6 & 5.73 & 5.36 & .37 & \\
\hline WO-2-185 & 17 & 3 & -.01 & .00 & .00 & .01 & .13 & .07 & -.8 & .4 & .00 & .00 & .00 & \\
\hline
\end{tabular}


Table 6. Basalt mass; initial and final aluminum, calcium, iron, magnesium, potassium, sodium, and strontium concentrations; initial and final specific conductance and $\mathrm{pH}$; and measured distribution coefficients of synthesized solutions - Continued

\begin{tabular}{|c|c|c|c|c|c|c|c|c|c|c|c|}
\hline $\begin{array}{l}\text { Sample } \\
\text { set }\end{array}$ & $\begin{array}{l}\text { Sample } \\
\text { number }\end{array}$ & $\begin{array}{l}\text { Sample } \\
\text { type }\end{array}$ & $\begin{array}{c}\text { Basalt } \\
\text { mass } \\
\text { (grams) }\end{array}$ & Initial pH & Final pH & $\begin{array}{c}\text { Initial } \\
\text { conductivity } \\
(\mu \mathrm{S} / \mathrm{cm})\end{array}$ & $\begin{array}{c}\text { Final } \\
\text { conductivity } \\
(\mu \mathrm{S} / \mathrm{cm})\end{array}$ & $\begin{array}{c}\text { Initial Al } \\
\text { (mg/L) }\end{array}$ & $\begin{array}{c}\text { Final Al } \\
(\mathrm{mg} / \mathrm{L})\end{array}$ & $\begin{array}{c}\text { Initial Ca } \\
(\mathrm{mg} / \mathrm{L})\end{array}$ & $\begin{array}{c}\text { Final Ca } \\
(\mathrm{mg} / \mathrm{L})\end{array}$ \\
\hline WO-2-186 & 1 & 1 & 1.9978 & 8.11 & 8.11 & 677 & 721 & .04 & 5.34 & 10.32 & 14.78 \\
\hline WO-2-186 & 3 & 1 & 2.0001 & 8.11 & 8.19 & 677 & 695 & .04 & 3.14 & 10.32 & $12.73^{\circ}$ \\
\hline WO-2-186 & 5 & 1 & 2.0041 & 8.16 & 8.17 & 559 & 589 & .04 & 1.90 & 10.89 & 12.80 \\
\hline WO-2-186 & 6 & 1 & 2.0024 & 8.16 & 8.03 & 559 & 863 & .04 & 1.94 & 10.89 & 12.40 \\
\hline WO-2-186 & 9 & 1 & 2.0009 & 8.19 & 8.17 & 534 & 561 & .04 & 3.38 & 10.56 & 13.49 \\
\hline WO-2-186 & 10 & 1 & 1.9956 & 8.19 & 8.11 & 534 & 389 & .04 & 1.39 & 10.56 & 11.88 \\
\hline WO-2-186 & 11 & 1 & 1.9990 & 8.19 & 8.11 & 534 & 684 & .04 & .95 & 10.56 & 11.48 \\
\hline WO-2-186 & 13 & 1 & 2.0009 & 8.32 & 8.18 & 617 & 628 & .04 & .96 & 10.96 & 12.41 \\
\hline WO-2-186 & 14 & 1 & 2.0034 & 8.32 & 8.29 & 617 & 522 & .04 & 1.40 & 10.96 & 12.46 \\
\hline WO-2-186 & 15 & 1 & 1.9994 & 8.32 & 8.35 & 617 & 516 & .04 & 1.13 & 10.96 & 12.40 \\
\hline WO-2-186 & 16 & 2 & & 8.03 & 8.32 & 573 & 617 & .05 & .04 & 11.86 & 10.96 \\
\hline WO-2-186 & 17 & 3 & & 4.63 & 7.45 & 35 & 182 & .00 & .00 & .01 & .14 \\
\hline
\end{tabular}


Table 6. Basalt mass; initial and final aluminum, calcium, iron, magnesium, potassium, sodium, and strontium concentrations; initial and final specific conductance and $\mathrm{pH}$; and measured distribution coefficients of synthesized solutions - Continued

\begin{tabular}{|c|c|c|c|c|c|c|c|c|c|c|c|c|c|c|}
\hline $\begin{array}{l}\text { Sample } \\
\text { set }\end{array}$ & $\begin{array}{l}\text { Sample } \\
\text { number }\end{array}$ & $\begin{array}{c}\text { Sample } \\
\text { type }\end{array}$ & $\begin{array}{c}\text { Initial } \\
\mathbf{F e} \\
(\mathrm{mg} / \mathrm{L})\end{array}$ & $\begin{array}{c}\text { Final Fe } \\
(\mathrm{mg} / \mathrm{L})\end{array}$ & $\begin{array}{c}\text { Initial } \\
\mathrm{Mg} \\
(\mathrm{mg} / \mathrm{l})\end{array}$ & $\begin{array}{c}\text { Final } \\
\mathrm{Mg} \\
(\mathrm{mg} / \mathrm{L})\end{array}$ & $\begin{array}{c}\text { Initial } \\
\mathbf{K} \\
(\mathrm{mg} / \mathrm{L})\end{array}$ & $\begin{array}{c}\text { Final K } \\
(\mathrm{mg} / \mathrm{L})\end{array}$ & $\begin{array}{c}\text { Initial } \\
\mathrm{Na} \\
(\mathrm{mg} / \mathrm{L})\end{array}$ & $\begin{array}{c}\text { Final } \\
\mathrm{Na} \\
(\mathrm{mg} / \mathrm{L})\end{array}$ & $\begin{array}{c}\text { Initial } \\
\mathrm{Sr} \\
(\mathrm{mg} / \mathrm{L})\end{array}$ & $\begin{array}{c}\text { Final Sr } \\
(\mathrm{mg} / \mathrm{L})\end{array}$ & $\Delta \mathrm{Sr}$ & Sr Kd \\
\hline WO-2-186 & 1 & 1 & .01 & 4.44 & 1.90 & 4.92 & 3.26 & 3.96 & 108.1 & 109.7 & .00 & .06 &. .06 & -9.74 \\
\hline WO-2-186 & 2 & 1 & .01 & 1.26 & 1.90 & 3.08 & 3.26 & 3.92 & 108.1 & 108.0 & .00 & .05 & -.05 & -9.67 \\
\hline WO-2-186 & 3 & 1 & .01 & 3.13 & 1.90 & 4.08 & 3.26 & 3.91 & 108.1 & 107.6 & .00 & .05 & -.05 & -9.69 \\
\hline WO-2-186 & 5 & 1 & .01 & 3.45 & 1.83 & 4.50 & 2.35 & 3.00 & 102.6 & 105.0 & 1.03 & .66 & .38 & 5.72 \\
\hline WO-2-186 & 6 & 1 & .01 & .89 & 1.83 & 2.83 & 2.35 & 3.01 & 102.6 & 103.1 & 1.03 & .62 & .41 & 6.58 \\
\hline WO-2-186 & 7 & 1 & .01 & 9.13 & 1.83 & 7.83 & 2.35 & 3.00 & 102.6 & 101.6 & 1.03 & .63 & .41 & 6.52 \\
\hline WO-2-186 & 9 & 1 & .00 & 1.75 & 1.83 & 3.25 & 2.40 & 3.16 & 101.2 & 101.7 & 2.56 & 1.61 & .94 & 5.85 \\
\hline WO-2-186 & 10 & 1 & .00 & .70 & 1.83 & 2.71 & 2.40 & 3.01 & 101.2 & 101.7 & 2.56 & 1.59 & .97 & 6.14 \\
\hline WO-2-186 & 11 & 1 & .00 & .46 & 1.83 & 2.56 & 2.40 & 3.04 & 101.2 & 101.1 & 2.56 & 1.58 & .98 & 6.23 \\
\hline WO-2-186 & 13 & 1 & .01 & .56 & 1.81 & 2.68 & 2.32 & 3.19 & 100.5 & 103.9 & 5.15 & 3.39 & 1.76 & 5.19 \\
\hline WO-2-186 & 14 & 1 & .01 & 1.09 & 1.81 & 2.94 & 2.32 & 3.15 & 100.5 & 101.8 & 5.15 & 3.29 & 1.86 & 5.65 \\
\hline WO-2-186 & 15 & 1 & .01 & 6.41 & 1.81 & 6.64 & 2.32 & 3.18 & 100.5 & 101.1 & 5.15 & 3.39 & 1.77 & 5.21 \\
\hline WO-2-186 & 4 & 2 & .01 & .01 & 2.06 & 1.90 & 3.63 & 3.26 & 112.1 & 108.1 & .00 & .00 & .00 & \\
\hline WO-2-186 & 8 & 2 & .00 & .01 & 2.02 & 1.83 & 2.49 & 2.35 & 106.4 & 102.6 & 1.13 & 1.03 & .10 & \\
\hline WO-2-186 & 12 & 2 & .00 & .00 & 2.02 & 1.83 & 2.59 & 2.40 & 106.1 & 101.2 & 2.80 & 2.56 & .24 & \\
\hline WO-2-186 & 16 & 2 & .00 & .01 & 2.03 & 1.81 & 2.52 & 2.32 & 109.6 & 100.5 & 5.73 & 5.15 & .57 & \\
\hline Wo-2-186 & 17 & 3 & -.01 & .00 & .00 & .01 & .13 & .10 & -.8 & -.3 & .00 & .00 & .00 & \\
\hline
\end{tabular}


Table 6. Basalt mass; initial and final aluminum, calcium, iron, magnesium, potassium, sodium, and strontium concentrations; initial and final specific conductance and $\mathrm{pH}$; and measured distribution coefficients of synthesized solutions - Continued

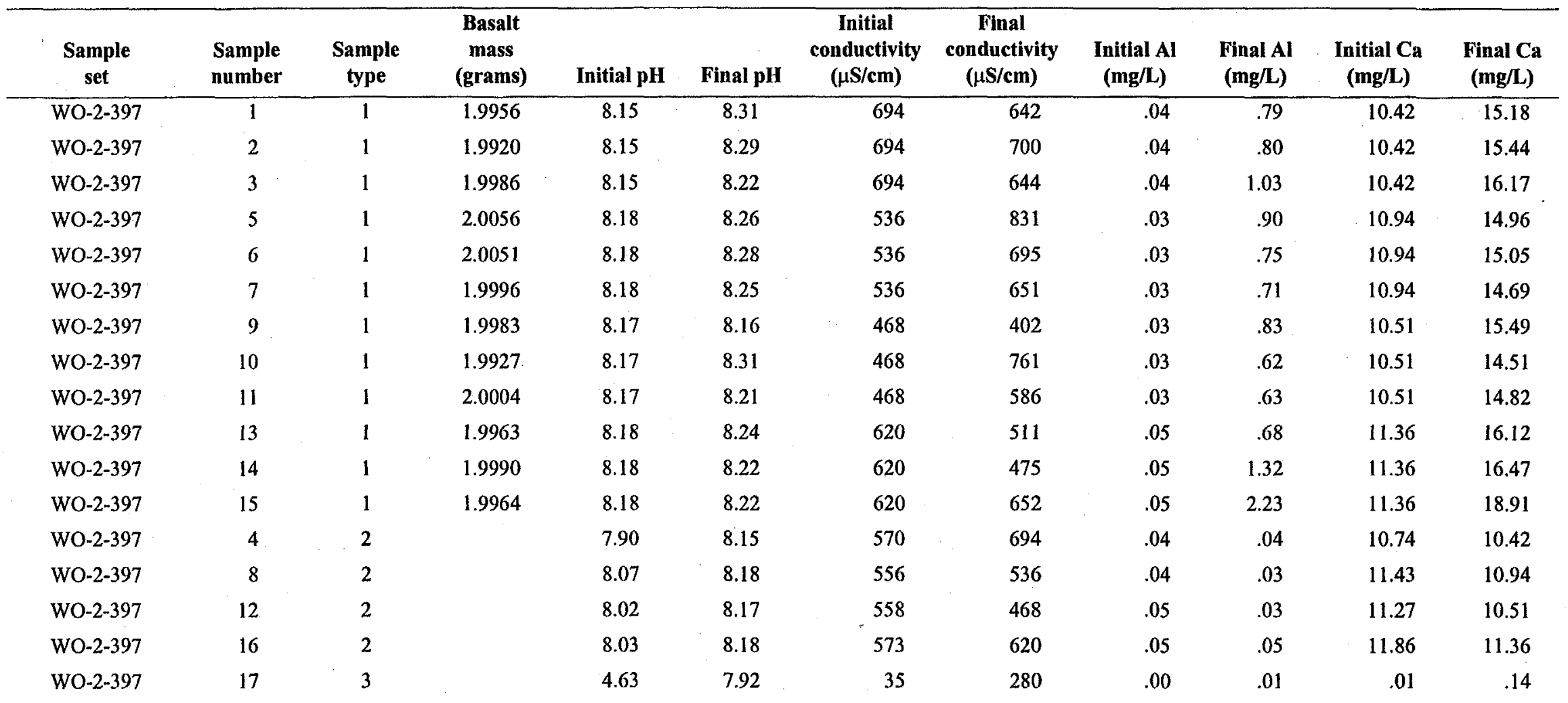


Table 6. Basalt mass; initial and final aluminum, calcium, iron, magnesium, potassium, sodium, and strontium concentrations; initial and final specific conductance and $\mathrm{pH}$; and measured distribution coefficients of synthesized solutions - Continued

\begin{tabular}{|c|c|c|c|c|c|c|c|c|c|c|c|c|c|c|}
\hline $\begin{array}{l}\text { Sample } \\
\text { set }\end{array}$ & $\begin{array}{l}\text { Sample } \\
\text { number }\end{array}$ & $\begin{array}{c}\text { Sample } \\
\text { type }\end{array}$ & $\begin{array}{c}\text { Initial } \\
\mathbf{F e} \\
(\mathbf{m g} / \mathbf{L})\end{array}$ & $\begin{array}{c}\text { Final } \\
\mathrm{Fe} \\
(\mathrm{mg} / \mathrm{L})\end{array}$ & $\begin{array}{c}\text { Initial } \\
\mathbf{M g} \\
(\mathbf{m g} / \mathbf{L})\end{array}$ & $\begin{array}{c}\text { Final } \\
\text { Mg } \\
(\mathrm{mg} / \mathrm{L})\end{array}$ & $\begin{array}{c}\text { Initial } \\
\mathbf{K} \\
(\mathrm{mg} / \mathrm{L})\end{array}$ & $\begin{array}{c}\text { Final K } \\
(\mathrm{mg} / \mathrm{L})\end{array}$ & $\begin{array}{c}\text { Initial } \\
\mathrm{Na} \\
(\mathrm{mg} / \mathrm{L})\end{array}$ & $\begin{array}{c}\text { Final } \\
\mathrm{Na} \\
(\mathrm{mg} / \mathrm{L})\end{array}$ & $\begin{array}{c}\text { Initial } \\
\mathbf{S r} \\
(\mathbf{m g} / \mathrm{L})\end{array}$ & $\begin{array}{c}\text { Final } \\
\text { Sr } \\
(\mathrm{mg} / \mathrm{L})\end{array}$ & $\Delta \mathrm{Sr}$ & Sr Kd \\
\hline WO-2-397 & 1 & 1 & .01 & 1.07 & 1.94 & 3.89 & 3.46 & 4.25 & 111.0 & 112.3 & .00 & .05 & -.05 & -9.71 \\
\hline WO-2-397 & 3 & 1 & .01 & 2.54 & 1.94 & 4.65 & 3.46 & 4.04 & 111.0 & 110.4 & .00 & .05 & -.05 & -9.70 \\
\hline WO-2-397 & 5 & 1 & .01 & 1.54 & 1.91 & 4.14 & 2.48 & 3.23 & 105.0 & 107.7 & 1.09 & .58 & .51 & 8.74 \\
\hline WO-2-397 & 6 & 1 & .01 & .88 & 1.91 & 3.71 & 2.48 & 3.20 & 105.0 & 104.6 & 1.09 & .58 & .51 & 8.67 \\
\hline WO-2-397 & 9 & 1 & .01 & 1.05 & 1.83 & 3.68 & 2.47 & 3.18 & 101.1 & 102.6 & 2.62 & 1.46 & 1.16 & 7.97 \\
\hline WO-2-397 & 10 & 1 & .01 & .86 & 1.83 & 3.65 & 2.47 & 3.17 & 101.1 & 101.2 & 2.62 & 1.42 & 1.21 & 8.57 \\
\hline WO-2-397 & 11 & 1 & .01 & .71 & 1.83 & 3.54 & 2.47 & 3.08 & 101.1 & 101.5 & 2.62 & 1.42 & 1.20 & 8.44 \\
\hline WO-2-397 & 13 & 1 & .01 & .79 & 1.93 & 3.93 & 2.35 & 3.14 & 107.8 & 109.4 & 5.47 & 3.18 & 2.30 & 7.26 \\
\hline WO-2-397 & 14 & 1 & .01 & 2.37 & 1.93 & 4.63 & 2.35 & 3.05 & 107.8 & 106.8 & 5.47 & 3.12 & 2.35 & 7.54 \\
\hline WO-2-397 & 15 & 1 & .01 & 14.51 & 1.93 & 10.88 & 2.35 & 3.04 & 107.8 & 106.9 & 5.47 & 3.13 & 2.34 & 7.50 \\
\hline WO-2-397 & 16 & 2 & .00 & .01 & 2.03 & 1.93 & 2.52 & 2.35 & 109.6 & 107.8 & 5.73 & 5.47 & .25 & \\
\hline WO-2-397 & 17 & 3 & -.01 & .00 & .00 & .01 & .13 & .07 & -.8 & .2 & .00 & .00 & .00 & \\
\hline
\end{tabular}


Table 6. Basalt mass; initial and final aluminum, calcium, iron, magnesium, potassium, sodium, and strontium concentrations; initial and final specific conductance and $\mathrm{pH}$; and measured distribution coefficients of synthesized solutions - Continued

\begin{tabular}{|c|c|c|c|c|c|c|c|c|c|c|c|}
\hline $\begin{array}{l}\text { Sample } \\
\text { set }\end{array}$ & $\begin{array}{l}\text { Sample } \\
\text { number }\end{array}$ & $\begin{array}{l}\text { Sample } \\
\text { type }\end{array}$ & $\begin{array}{c}\text { Basalt } \\
\text { mass } \\
\text { (grams) }\end{array}$ & Initial pH & Final pH & $\begin{array}{c}\text { Initial } \\
\text { conductivity } \\
(\mu \mathrm{S} / \mathrm{cm})\end{array}$ & $\begin{array}{c}\text { Final } \\
\text { conductivity } \\
(\mu \mathrm{S} / \mathrm{cm})\end{array}$ & $\begin{array}{c}\text { Initial AI } \\
(\mathrm{mg} / \mathrm{L})\end{array}$ & $\begin{array}{c}\text { Final Al } \\
(\mathrm{mg} / \mathrm{L})\end{array}$ & $\begin{array}{c}\text { Initial Ca } \\
(\mathrm{mg} / \mathrm{L})\end{array}$ & $\begin{array}{c}\text { Final Ca } \\
(\mathrm{mg} / \mathrm{L})\end{array}$ \\
\hline WO-2-400 & 1 & 1 & 2.0068 & 8.11 & 8.25 & 695 & 640 & .03 & 1.31 & 10.10 & 11.00 \\
\hline WO-2-400 & 2 & 1 & 2.0087 & 8.11 & 8.27 & 695 & 597 & .03 & 1.23 & 10.10 & 10.45 \\
\hline WO-2-400 & 3 & 1 & 1.9956 & 8.11 & 8.29 & 695 & 801 & .03 & 1.24 & 10.10 & 10.74 \\
\hline WO-2-400 & 5 & 1. & 2.0098 & 8.14 & 8.19 & 591 & 600 & .04 & 1.15 & 10.64 & 11.31 \\
\hline Wo-2-400 & 6 & 1 & 2.0091 & 8.14 & 8.22 & 591 & 565 & .04 & .86 & 10.64 & 10.81 \\
\hline WO-2-400 & 7 & 1 & 1.9997 & 8.14 & 8.25 & 591 & 634 & .04 & 1.35 & 10.64 & 11.30 \\
\hline WO-2-400 & 9 & 1 & 1.9940 & 8.15 & 8.13 & 648 & 565 & .03 & 1.14 & 10.36 & 11.07 \\
\hline WO-2-400 & 10 & 1 & 2.0003 & 8.15 & 8.14 & 648 & 446 & .03 & .97 & 10.36 & 11.18 \\
\hline WO-2-400 & 11 & 1 & 1.9999 & 8.15 & 8.07 & 648 & 631 & .03 & 1.03 & 10.36 & 11.06 \\
\hline WO-2-400 & 13 & 1 & 2.0014 & 8.27 & 8.10 & 1,255 & 551 & .04 & .82 & 11.46 & 12.39 \\
\hline Wo-2-400 & 14 & 1 & 2.0051 & 8.27 & 8.15 & 1,255 & 648 & .04 & 1.02 & 11.46 & 12.36 \\
\hline WO-2-400 & 15 & 1 & 2.0071 & 8.27 & 8.18 & 1,255 & 654 & .04 & .94 & 11.46 & 12.28 \\
\hline WO- $2-400$ & 4 & 2 & & 7.91 & 8.11 & 559 & 695 & .04 & .03 & 10.74 & 10.10 \\
\hline WO-2-400 & 8 & 2 & & 8.09 & 8.14 & 546 & 591 & .04 & .04 & 11.43 & 10.64 \\
\hline WO- $2-400$ & 12 & 2 & & 8.02 & 8.15 & 542 & 648 & .05 & .03 & 11.27 & 10.36 \\
\hline WO-2-400 & 16 & 2 & & 8.05 & 8.27 & 560 & 1,255 & .05 & .04 & 11.86 & 11.46 \\
\hline WO-2-400 & 17 & 3 & & 8.25 & 8.07 & 11 & 178 & .00 & .01 & .01 & .18 \\
\hline
\end{tabular}


Table 6. Basalt mass; initial and final aluminum, calcium, iron, magnesium, potassium, sodium, and strontium concentrations; initial and final specific conductance and $\mathrm{pH}$; and measured distribution coefficients of synthesized solutions - Continued

\begin{tabular}{|c|c|c|c|c|c|c|c|c|c|c|c|c|c|c|}
\hline $\begin{array}{l}\text { Sample } \\
\text { set }\end{array}$ & $\begin{array}{l}\text { Sample } \\
\text { number }\end{array}$ & $\begin{array}{c}\text { Sample } \\
\text { type }\end{array}$ & $\begin{array}{c}\text { Initial } \\
\mathrm{Fe} \\
(\mathrm{mg} / \mathrm{L})\end{array}$ & $\begin{array}{r}\text { FinalFe } \\
(\mathrm{mg} / \mathrm{L})\end{array}$ & $\begin{array}{c}\text { Initial } \\
\mathbf{M g} \\
(\mathrm{mg} / \mathrm{L})\end{array}$ & $\begin{array}{c}\text { Final } \\
\mathbf{M g} \\
(\mathbf{m g} / \mathbf{L})\end{array}$ & $\begin{array}{c}\text { Initial } \\
\mathbf{K} \\
(\mathrm{mg} / \mathrm{L})\end{array}$ & $\begin{array}{c}\text { Final K } \\
(\mathrm{mg} / \mathrm{L})\end{array}$ & $\begin{array}{c}\text { Initial } \\
\mathrm{Na} \\
(\mathrm{mg} / \mathrm{L})\end{array}$ & $\begin{array}{c}\text { Final } \\
\mathrm{Na} \\
(\mathrm{mg} / \mathrm{L})\end{array}$ & $\begin{array}{c}\text { Initial } \\
\mathrm{Sr} \\
(\mathrm{mg} / \mathrm{L})\end{array}$ & $\begin{array}{c}\text { Final Sr } \\
(\mathrm{mg} / \mathrm{L})\end{array}$ & $\Delta \mathbf{S r}$ & Sr Kd \\
\hline WO-2-400 & 1 & 1 & .00 & 1.38 & 1.91 & 3.26 & 3.42 & 4.19 & 107.3 & 110.2 & .02 & .04 & -.03 & -6.33 \\
\hline WO-2-400 & 2 & 1 & .00 & 1.10 & 1.91 & 3.08 & 3.42 & 4.07 & 107.3 & 108.3 & .02 & .04 & -.03 & -6.11 \\
\hline WO- $2-400$ & 3 & 1 & .00 & 1.36 & 1.91 & 3.27 & 3.42 & 4.03 & 107.3 & 109.0 & .02 & .04 & -.03 & -6.22 \\
\hline WO-2-400 & 5 & 1 & .00 & 2.00 & 1.87 & 3.70 & 2.36 & 3.19 & 104.0 & 104.9 & 1.04 & .60 & .44 & 7.29 \\
\hline WO-2-400 & 6 & 1 & .00 & .65 & 1.87 & 2.89 & 2.36 & 3.19 & 104.0 & 104.7 & 1.04 & .59 & .45 & 7.66 \\
\hline WO-2-400 & 7 & 1 & .00 & 2.56 & 1.87 & 3.90 & 2.36 & 3.21 & 104.0 & 105.2 & 1.04 & .62 & .43 & 6.87 \\
\hline WO-2-400 & 9 & 1 & .00 & 1.36 & 1.83 & 3.19 & 2.44 & 3.29 & 100.8 & 103.2 & 2.58 & 1.53 & 1.05 & 6.83 \\
\hline WO-2-400 & 10 & 1 & .00 & .74 & 1.83 & 2.84 & 2.44 & 3.28 & 100.8 & 100.6 & 2.58 & 1.55 & 1.03 & 6.66 \\
\hline WO- $2-400$ & 11 & 1 & .00 & .79 & 1.83 & 2.88 & 2.44 & 3.23 & 100.8 & 100.3 & 2.58 & 1.56 & 1.02 & 6.58 \\
\hline WO-2-400 & 13 & 1 & .01 & .67 & 1.94 & 3.14 & 2.33 & 3.17 & 104.2 & 107.9 & 5.46 & 3.42 & 2.04 & 5.97 \\
\hline WO-2-400 & 14 & 1 & .01 & .91 & 1.94 & 3.21 & 2.33 & 3.12 & 104.2 & 104.3 & 5.46 & 3.45 & 2.01 & 5.81 \\
\hline WO-2-400 & 15 & 1 & .01 & .68 & 1.94 & 3.09 & 2.33 & 3.08 & 104.2 & 105.4 & 5.46 & 3.44 & 2.02 & 5.84 \\
\hline WO-2-400 & 4 & 2 & .01 & .00 & 2.06 & 1.91 & 3.63 & 3.42 & 112.1 & 107.3 & .00 & .00 & .00 & \\
\hline WO-2-400 & 8 & 2 & .00 & .00 & 2.02 & 1.87 & 2.49 & 2.36 & 106.4 & 104.0 & 1.13 & 1.04 & .09 & \\
\hline WO-2-400 & 12 & 2 & .00 & .00 & 2.02 & 1.83 & 2.59 & 2.44 & 106.1 & 100.8 & 2.80 & 2.58 & .22 & \\
\hline WO-2-400 & 16 & 2 & .00 & .01 & 2.03 & 1.94 & 2.52 & 2.33 & 109.6 & 104.2 & 5.73 & 5.46 & .27 & \\
\hline WO-2-400 & 17 & 3 & -.01 & .01 & .00 & .01 & .13 & .09 & -.8 & .7 & .00 & .00 & .00 & \\
\hline
\end{tabular}


Table 6. Basalt mass; initial and final aluminum, calcium, iron, magnesium, potassium, sodium, and strontium concentrations; initial and final specific conductance and $\mathrm{pH}$; and measured distribution coefficients of synthesized solutions - Continued

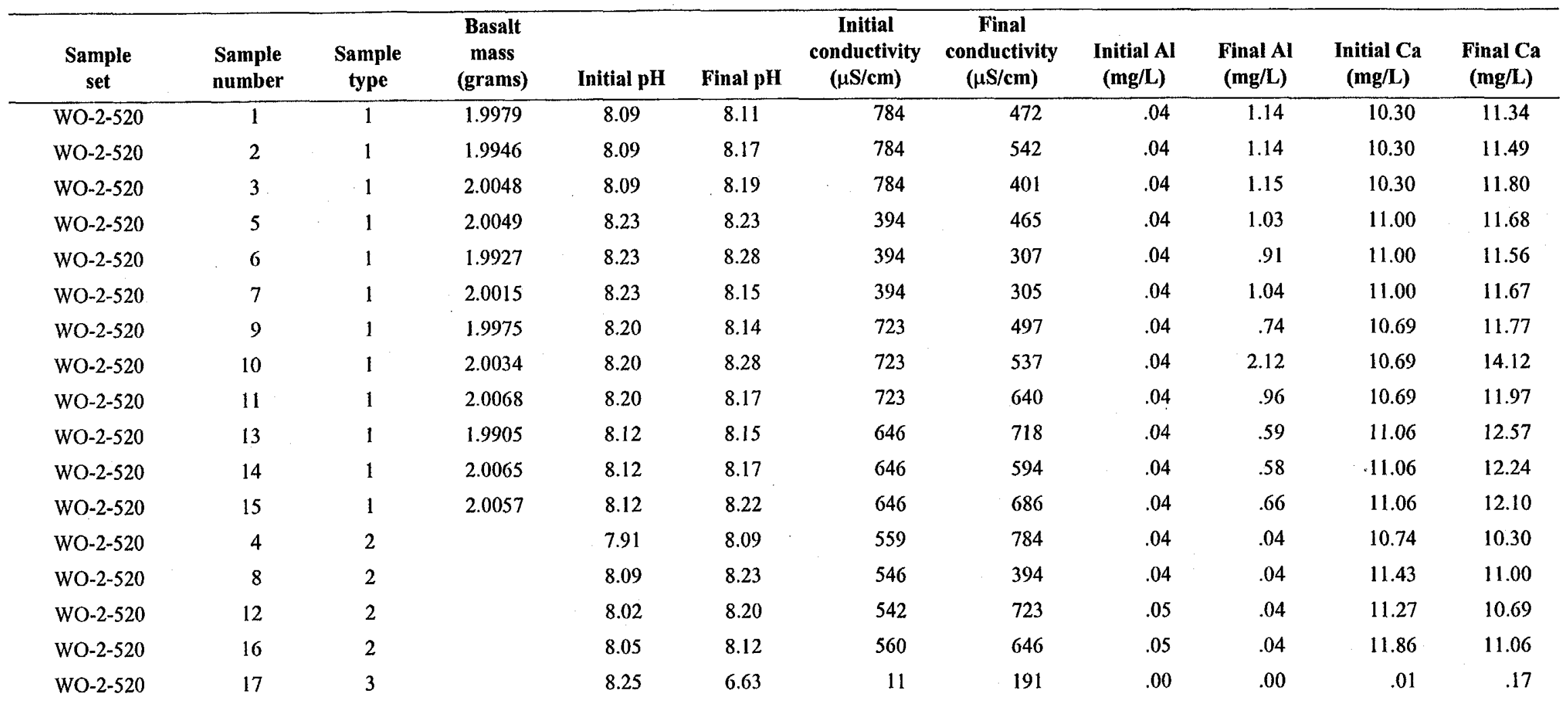


Table 6. Basalt mass; initial and final aluminum, calcium, iron, magnesium, potassium, sodium, and strontium concentrations; initial and final specific conductance and $\mathrm{pH}$; and measured distribution coefficients of synthesized solutions - Continued

\begin{tabular}{|c|c|c|c|c|c|c|c|c|c|c|c|c|c|c|}
\hline $\begin{array}{c}\text { Sample } \\
\text { set }\end{array}$ & $\begin{array}{l}\text { Sample } \\
\text { number }\end{array}$ & $\begin{array}{c}\text { Sample } \\
\text { type }\end{array}$ & $\begin{array}{c}\text { Initial } \\
\mathrm{Fe} \\
(\mathrm{mg} / \mathrm{L})\end{array}$ & $\begin{array}{c}\text { Final Fe } \\
(\mathrm{mg} / \mathrm{L})\end{array}$ & $\begin{array}{c}\text { Initial } \\
\mathrm{Mg} \\
(\mathrm{mg} / \mathrm{L})\end{array}$ & $\begin{array}{c}\text { Final } \\
\mathrm{Mg} \\
(\mathrm{mg} / \mathrm{L})\end{array}$ & $\begin{array}{c}\text { Initial } \\
\mathrm{K} \\
(\mathrm{mg} / \mathrm{L})\end{array}$ & $\begin{array}{c}\text { Final K } \\
(\mathrm{mg} / \mathrm{L})\end{array}$ & $\begin{array}{c}\text { Initial } \\
\mathrm{Na} \\
(\mathrm{mg} / \mathrm{L})\end{array}$ & $\begin{array}{c}\text { Final } \\
\mathrm{Na} \\
(\mathrm{mg} / \mathrm{L})\end{array}$ & $\begin{array}{c}\text { Initial } \\
\mathrm{Sr} \\
(\mathrm{mg} / \mathrm{L})\end{array}$ & $\begin{array}{r}\text { Final Sr } \\
(\mathrm{mg} / \mathrm{L})\end{array}$ & $\Delta \mathbf{S r}$ & Sr Kd \\
\hline WO-2-520 & 1 & 1 & .01 & 1.50 & 1.92 & 4.04 & 3.37 & 3.72 & 105.1 & 105.1 & .00 & .07 & -.07 & -9.77 \\
\hline WO-2-520 & 2 & 1 & .01 & 1.42 & 1.92 & 4.15 & 3.37 & 3.86 & 105.1 & 105.6 & .00 & .07 & -.07 & -9.79 \\
\hline WO-2-520 & 3 & 1 & .01 & 1.61. & 1.92 & 4.23 & 3.37 & 3.81 & 105.1 & 103.8 & .00 & .07 & -.07 & -9.74 \\
\hline WO-2-520 & 5 & 1 & .01 & 1.48 & 1.91 & 4.08 & 2.40 & 3.09 & 102.3 & 102.2 & 1.06 & .36 & .71 & 19.68 \\
\hline WO-2-520 & 6 & 1 & .01 & 1.08 & 1.91 & 4.04 & 2.40 & 3.10 & 102.3 & 101.4 & 1.06 & .35 & .71 & 20.06 \\
\hline WO-2-520 & 7 & 1 & .01 & 1.57 & 1.91 & 4.23 & 2.40 & 3.15 & 102.3 & 100.9 & 1.06 & .36 & .71 & 19.76 \\
\hline WO-2-520 & 9 & 1 & .01 & .87 & 1.94 & 4.11 & 2.41 & 3.18 & 103.9 & 105.5 & 2.68 & .87 & 1.81 & 20.95 \\
\hline WO-2-520 & 10 & 1 & .01 & 14.95 & 1.94 & 10.90 & 2.41 & 3.23 & 103.9 & 103.3 & 2.68 & .88 & 1.79 & 20.27 \\
\hline WO-2-520 & 11 & 1 & .01 & 1.51 & 1.94 & 4.24 & 2.41 & 3.20 & 103.9 & 101.2 & 2.68 & .86 & 1.82 & 21.18 \\
\hline WO-2-520 & 13 & 1 & .01 & .64 & 1.89 & 4.20 & 2.30 & 3.07 & 106.6 & 106.7 & 5.34 & 1.85 & 3.49 & 18.99 \\
\hline WO-2-520 & 14 & 1 & .01 & .96 & 1.89 & 4.15 & 2.30 & 3.03 & 106.6 & 103.9 & 5.34 & 1.81 & 3.53 & 19.41 \\
\hline WO-2-520 & 15 & 1 & .01 & .84 & 1.89 & 4.01 & 2.30 & 2.97 & 106.6 & 101.3 & 5.34 & 1.76 & 3.58 & 20.25 \\
\hline WO-2-520 & 4 & 2 & .01 & .01 & 2.06 & 1.92 & 3.63 & 3.37 & 112.1 & 105.1 & .00 & .00 & .00 & \\
\hline WO-2-520 & 8 & 2 & .00 & .01 & 2.02 & 1.91 & 2.49 & 2.40 & 106.4 & 102.3 & 1.13 & 1.06 & .07 & \\
\hline WO-2-520 & 12 & 2 & .00 & .01 & 2.02 & 1.94 & 2.59 & 2.41 & 106.1 & 103.9 & 2.80 & 2.68 & .13 & \\
\hline WO-2-520 & 16 & 2 & .00 & .01 & 2.03 & 1.89 & 2.52 & 2.30 & 109.6 & 106.6 & 5.73 & 5.34 & .38 & \\
\hline WO- $2-520$ & 17 & 3 & -.01 & .01 & .00 & .01 & .13 & .09 & -.8 & .3 & .00 & .00 & .00 & \\
\hline
\end{tabular}


Table 6. Basalt mass; initial and final aluminum, calcium, iron, magnesium, potassium, sodium, and strontium concentrations; initial and final specific conductance and $\mathrm{pH}$; and measured distribution coefficients of synthesized solutions - Continued

\begin{tabular}{|c|c|c|c|c|c|c|c|c|c|c|c|}
\hline $\begin{array}{l}\text { Sample } \\
\text { set }\end{array}$ & $\begin{array}{l}\text { Sample } \\
\text { number }\end{array}$ & $\begin{array}{l}\text { Sample } \\
\text { type }\end{array}$ & $\begin{array}{l}\text { Basalt mass } \\
\text { (grams) }\end{array}$ & Initial pH & Final pH & $\begin{array}{c}\text { Initial } \\
\text { conductivity } \\
(\mu \mathrm{S} / \mathrm{cm})\end{array}$ & $\begin{array}{c}\text { Final } \\
\text { conductivity } \\
(\mu \mathrm{S} / \mathrm{cm})\end{array}$ & $\begin{array}{c}\text { Initial Al } \\
(\mathrm{mg} / \mathrm{L})\end{array}$ & $\begin{array}{c}\text { Final Al } \\
(\mathrm{mg} / \mathrm{L})\end{array}$ & $\begin{array}{c}\text { Initial Ca } \\
\text { (mg/L) }\end{array}$ & $\begin{array}{c}\text { Final Ca } \\
(\mathrm{mg} / \mathrm{L})\end{array}$ \\
\hline TAN CH1 83 & 1 & 1 & 2.0042 & 8.25 & 8.08 & 921 & 671 & .04 & 4.18 & 10.15 & 12.75 \\
\hline TAN CH1 83 & 3 & 1 & 2.0024 & 8.25 & 8.13 & 921 & 593 & .04 & 3.19 & 10.15 & 12.05 \\
\hline TAN CH1 83 & 5 & 1 & 2.0014 & 8.23 & 8.21 & 612 & 522 & .04 & 2.48 & 10.68 & 12.24 \\
\hline TAN CH1 83 & 6 & 1 & 2.0085 & 8.23 & 8.35 & 612 & 482 & .04 & 2.59 & 10.68 & 12.12 \\
\hline TAN CHI 83 & 9 & 1 & 2.0023 & 8.19 & 8.08 & 627 & 533 & .04 & 1.42 & 10.82 & 12.92 \\
\hline TAN CH1 83 & 10 & 1 & 1.9997 & 8.19 & 8.17 & 627 & 523 & .04 & 1.34 & 10.82 & 12.65 \\
\hline TAN CH1 83 & 11 & 1 & 2.0052 & 8.19 & 8.23 & 627 & 559 & .04 & 1.53 & 10.82 & 12.89 \\
\hline TAN CHI 83 & 13 & 1 & 2.0039 & 8.14 & 7.89 & 557 & 619 & .05 & 1.32 & 11.49 & 13.98 \\
\hline TAN CH1 83 & 14 & 1 & 2.0004 & 8.14 & 7.97 & 557 & 620 & .05 & .63 & 11.49 & 13.44 \\
\hline TAN CH1 83 & 15 & 1 & 1.9966 & 8.14 & 8.07 & 557 & 579 & .05 & 1.52 & 11.49 & 13.95 \\
\hline TAN CH1 83 & 16 & 2 & & 8.05 & 8.14 & 560 & 557 & .05 & .05 & 11.86 & 11.49 \\
\hline TAN CH1 83 & 17 & 3 & & 8.25 & 7.95 & 11 & 145 & .00 & .01 & .01 & .20 \\
\hline
\end{tabular}


Table 6. Basalt mass; initial and final aluminum, calcium, iron, magnesium, potassium, sodium, and strontium concentrations; initial and final specific conductance and $\mathrm{pH}$; and measured distribution coefficients of synthesized solutions - Continued

\begin{tabular}{|c|c|c|c|c|c|c|c|c|c|c|c|c|c|c|}
\hline $\begin{array}{l}\text { Sample } \\
\text { set }\end{array}$ & $\begin{array}{l}\text { Sample } \\
\text { number }\end{array}$ & $\begin{array}{c}\text { Sample } \\
\text { type }\end{array}$ & $\begin{array}{c}\text { Initial } \\
\text { Fe } \\
(\mathrm{mg} / \mathrm{L})\end{array}$ & $\begin{array}{c}\text { Final } \\
\text { Fe } \\
(\mathrm{mg} / \mathrm{L})\end{array}$ & $\begin{array}{c}\text { Initial } \\
\mathrm{Mg} \\
(\mathrm{mg} / \mathrm{L})\end{array}$ & $\begin{array}{c}\text { Final } \\
\mathrm{Mg} \\
(\mathrm{mg} / \mathrm{L})\end{array}$ & $\begin{array}{c}\text { Initial } \\
\mathbf{K} \\
(\mathrm{mg} / \mathrm{L})\end{array}$ & $\begin{array}{c}\text { Final K } \\
(\mathrm{mg} / \mathrm{L})\end{array}$ & $\begin{array}{c}\text { Initial } \\
\mathrm{Na} \\
(\mathrm{mg} / \mathrm{L})\end{array}$ & $\begin{array}{c}\text { Final } \\
\mathrm{Na} \\
(\mathrm{mg} / \mathrm{L})\end{array}$ & $\begin{array}{c}\text { Initial } \\
\mathrm{Sr} \\
(\mathrm{mg} / \mathrm{L})\end{array}$ & $\begin{array}{c}\text { Final } \\
\mathrm{Sr} \\
(\mathrm{mg} / \mathrm{L})\end{array}$ & $\Delta \mathbf{S r}$ & Sr Kd \\
\hline TAN CH1 83 & 1 & 1 & .00 & 2.37 & 1.87 & 3.09 & 3.55 & 4.22 & 108.9 & 106.6 & .00 & .08 & -.08 & -9.82 \\
\hline TAN CH1 83 & 2 & 1 & .00 & 1.31 & 1.87 & 2.73 & 3.55 & 4.21 & 108.9 & 108.2 & .00 & .08 & -.07 & -9.82 \\
\hline TAN CH1 83 & 3 & 1 & .00 & 1.23 & 1.87 & 2.70 & 3.55 & 4.18 & 108.9 & 107.5 & .00 & .08 & -.07 & -9.81 \\
\hline TAN CH 183 & 5 & 1 & .01 & .97 & 1.81 & 2.57 & 2.40 & 3.28 & 103.4 & 103.9 & 1.04 & .52 & .52 & 9.91 \\
\hline TAN CH1 83 & 6 & 1 & .01 & 1.46 & 1.81 & 2.68 & 2.40 & 3.25 & 103.4 & 101.5 & 1.04 & .51 & .54 & 10.48 \\
\hline TAN CH1 83 & 7 & 1 & .01 & 1.41 & 1.81 & 2.67 & 2.40 & 3.27 & 103.4 & 101.6 & 1.04 & .53 & .52 & 9.78 \\
\hline TAN CHI 83 & 9 & 1 & .01 & .58 & 1.91 & 2.62 & 2.45 & 3.40 & 104.8 & 105.8 & 2.68 & 1.34 & 1.34 & 10.02 \\
\hline TAN CH1 83 & 10 & 1 & .01 & 1.25 & 1.91 & 2.86 & 2.45 & 3.26 & 104.8 & 103.3 & 2.68 & 1.32 & 1.35 & 10.25 \\
\hline TAN CH1 83 & 11 & 1 & .01 & 2.38 & 1.91 & 3.37 & 2.45 & 3.33 & 104.8 & 102.5 & 2.68 & 1.30 & 1.38 & 10.60 \\
\hline TAN CH1 83 & 13 & 1 & .01 & .80 & 1.94 & 2.82 & 2.37 & 3.26 & 106.6 & 107.7 & 5.50 & 2.90 & 2.60 & 8.93 \\
\hline TAN CH1 83 & 14 & 1 & .01 & .35 & 1.94 & 2.55 & 2.37 & 3.22 & 106.6 & 108.2 & 5.50 & 2.89 & 2.61 & 9.00 \\
\hline TAN CH1 83 & 15 & 1 & .01 & 1.92 & 1.94 & 3.27 & 2.37 & 3.30 & 106.6 & 106.2 & 5.50 & 2.83 & 2.66 & 9.41 \\
\hline TAN CH 183 & 4 & 2 & .01 & .00 & 2.06 & 1.87 & 3.63 & 3.55 & 112.1 & 108.9 & .00 & .00 & .00 & \\
\hline TAN CH1 83 & 8 & 2 & .00 & .01 & 2.02 & 1.81 & 2.49 & 2.40 & 106.4 & 103.4 & 1.13 & 1.04 & .09 & \\
\hline TAN CH1 83 & 12 & 2 & .00 & .01 & 2.02 & 1.91 & 2.59 & 2.45 & 106.1 & 104.8 & 2.80 & 2.68 & .12 & \\
\hline TAN CH1 83 & 16 & 2 & .00 & .01 & 2.03 & 1.94 & 2.52 & 2.37 & 109.6 & 106.6 & 5.73 & 5.50 & .23 & \\
\hline TAN CH1 83 & 17 & 3 & -.01 & .00 & .00 & .01 & .13 & .04 & -.8 & -.1 & .00 & .00 & .00 & \\
\hline
\end{tabular}


Table 6. Basalt mass; initial and final aluminum, calcium, iron, magnesium, potassium, sodium, and strontium concentrations; initial and final specific conductance and $\mathrm{pH}$; and measured distribution coefficients of synthesized solutions - Continued

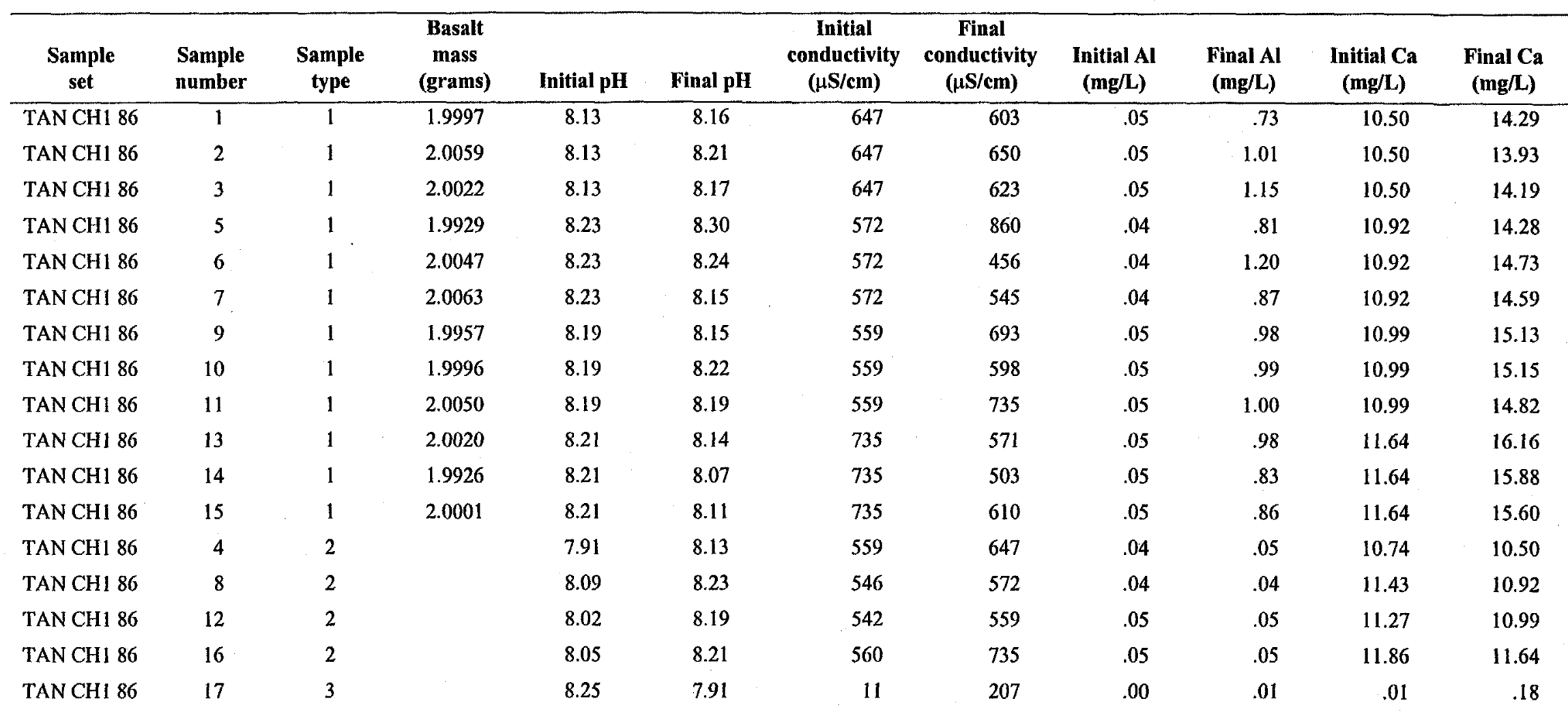


Table 6. Basalt mass; initial and final aluminum, calcium, iron, magnesium, potassium, sodium, and strontium concentrations; initial and final specific conductance and $\mathrm{pH}$; and measured distribution coefficients of synthesized solutions - Continued

\begin{tabular}{|c|c|c|c|c|c|c|c|c|c|c|c|c|c|c|}
\hline $\begin{array}{l}\text { Sample } \\
\text { set }\end{array}$ & $\begin{array}{l}\text { Sample } \\
\text { number }\end{array}$ & $\begin{array}{c}\text { Sample } \\
\text { type }\end{array}$ & $\begin{array}{c}\text { Initial } \\
\text { Fe } \\
(\mathrm{mg} / \mathrm{L})\end{array}$ & $\begin{array}{c}\text { Final Fe } \\
(\mathbf{m g} / \mathbf{L})\end{array}$ & $\begin{array}{c}\text { Initial } \\
\mathrm{Mg} \\
(\mathrm{mg} / \mathrm{L})\end{array}$ & $\begin{array}{c}\text { Final } \\
\text { Mg } \\
(\mathbf{m g} / \mathbf{L})\end{array}$ & $\begin{array}{c}\text { Initial K } \\
(\mathbf{m g} / \mathbf{L})\end{array}$ & $\begin{array}{c}\text { Final K } \\
(\mathrm{mg} / \mathrm{L})\end{array}$ & $\begin{array}{c}\text { Initial } \\
\mathrm{Na} \\
(\mathrm{mg} / \mathrm{L})\end{array}$ & $\begin{array}{c}\text { Final } \\
\mathrm{Na} \\
(\mathrm{mg} / \mathrm{L})\end{array}$ & $\begin{array}{c}\text { Initial } \\
\mathrm{Sr} \\
(\mathrm{mg} / \mathrm{L})\end{array}$ & $\begin{array}{c}\text { Final Sr } \\
(\mathbf{m g} / \mathbf{L})\end{array}$ & $\Delta \mathbf{S r}$ & Sr Kd \\
\hline TAN CH1 86 & 1 & 1 & .00 & .22 & 1.99 & 3.00 & 3.59 & 4.36 & 109.4 & 111.2 & .00 & .14 &. .14 & -9.97 \\
\hline TAN CHI 86 & 3 & 1 & .00 & .61 & 1.99 & 3.22 & 3.59 & 4.26 & 109.4 & 107.9 & .00 & .14 & -.14 & -9.95 \\
\hline TAN CH1 86 & 5 & 1 & .00 & .32 & 1.93 & 3.03 & 2.50 & 3.61 & 104.9 & 103.1 & 1.07 & .38 & .70 & 18.62 \\
\hline TAN CH1 86 & 6 & 1 & .00 & .79 & 1.93 & 3.42 & 2.50 & 3.43 & 104.9 & 101.4 & 1.07 & .36 & .71 & 19.41 \\
\hline TAN CH1 86 & 9 & 1 & .00 & 1.45 & 1.98 & 4.11 & 2.58 & 3.62 & 104.8 & 100.6 & 2.76 & .77 & 1.99 & 25.86 \\
\hline TAN CH1 86 & 10 & 1 & .00 & .66 & 1.98 & 3.41 & 2.58 & 3.66 & 104.8 & 100.5 & 2.76 & .74 & 2.01 & 27.15 \\
\hline TAN CH1 86 & 11 & 1 & .00 & .32 & 1.98 & 3.16 & 2.58 & 3.66 & 104.8 & 100.4 & 2.76 & .72 & 2.03 & 28.09 \\
\hline TAN CH1 86 & 13 & 1 & .01 & .53 & 1.98 & 3.43 & 2.44 & 3.55 & 104.8 & 104.1 & 5.58 & 1.54 & 4.04 & 26.26 \\
\hline TAN CH1 86 & 14 & 1 & .01 & .44 & 1.98 & 3.36 & 2.44 & 3.63 & 104.8 & 103.6 & 5.58 & 1.57 & 4.01 & 25.67 \\
\hline TAN CH1 86 & 15 & 1 & .01 & .38 & 1.98 & 3.21 & 2.44 & 3.57 & 104.8 & 102.6 & 5.58 & 1.52 & 4.06 & 26.63 \\
\hline TAN CH1 86 & 16 & 2 & .00 & .01 & 2.03 & 1.98 & 2.52 & 2.44 & 109.6 & 104.8 & 5.73 & 5.58 & .15 & \\
\hline TAN CH1 86 & 17 & 3 & -.01 & .00 & .00 & .01 & .13 & .14 & -.8 & .3 & .00 & .00 & .00 & \\
\hline
\end{tabular}


Table 6. Basalt mass; initial and final aluminum, calcium, iron, magnesium, potassium, sodium, and strontium concentrations; initial and final specific conductance and $\mathrm{pH}$; and measured distribution coefficients of synthesized solutions - Continued

\begin{tabular}{|c|c|c|c|c|c|c|c|c|c|c|c|}
\hline $\begin{array}{l}\text { Sample } \\
\text { set }\end{array}$ & $\begin{array}{l}\text { Sample } \\
\text { number }\end{array}$ & $\begin{array}{c}\text { Sample } \\
\text { type }\end{array}$ & $\begin{array}{c}\text { Basalt } \\
\text { mass } \\
\text { (grams) }\end{array}$ & Initial pH & Final pH & $\begin{array}{c}\text { Initial } \\
\text { conductivity } \\
(\mu \mathrm{S} / \mathrm{cm})\end{array}$ & $\begin{array}{c}\text { Final } \\
\text { conductivity } \\
(\mu \mathrm{S} / \mathrm{cm})\end{array}$ & $\begin{array}{c}\text { Initial Al } \\
\text { (mg/L) }\end{array}$ & $\begin{array}{c}\text { Final Al } \\
(\mathrm{mg} / \mathrm{L})\end{array}$ & $\begin{array}{c}\text { Initial Ca } \\
\text { (mg/L) }\end{array}$ & $\begin{array}{c}\text { Final Ca } \\
(\mathrm{mg} / \mathrm{L})\end{array}$ \\
\hline TAN CH 128 & 1 & 1 & 1.9937 & 8.22 & 8.16 & 607 & 473 & .05 & 2.30 & 10.69 & 12.62 \\
\hline TAN CH1 128 & 2 & 1 & 1.9952 & 8.22 & 8.37 & 607 & 641 & .05 & 1.79 & 10.69 & 12.18 \\
\hline TAN CH1 128 & 3 & 1 & 2.0021 & 8.22 & 8.31 & 607 & 578 & .05 & 1.65 & 10.69 & 12.12 \\
\hline TAN CH1 128 & 5 & 1 & 1.9931 & 8.18 & 8.31 & 586 & 764 & .05 & 1.34 & 11.10 & 12.58 \\
\hline TAN CH1 128 & 6 & 1 & 1.9977 & 8.18 & 8.20 & 586 & 666 & .05 & 2.02 & 11.10 & 13.05 \\
\hline TAN CH1 128 & 7 & 1 & 1.9986 & 8.18 & 8.19 & 586 & 653 & .05 & 1.47 & 11.10 & 12.48 \\
\hline TAN CH1 128 & 9 & 1 & 1.9967 & 8.21 & 8.06 & 612 & 504 & .05 & 1.55 & 10.77 & 13.19 \\
\hline TAN CH1 128 & 10 & 1 & 1.9963 & 8.21 & 8.16 & 612 & 1,067 & .05 & 1.36 & 10.77 & 12.83 \\
\hline TAN CH 1128 & 11 & 1 & 2.0081 & 8.21 & 8.13 & 612 & 534 & .05 & 1.90 & 10.77 & 13.14 \\
\hline TAN CH1 128 & 13 & 1 & 1.9952 & 8.18 & 8.11 & 605 & 635 & .05 & 1.53 & 11.32 & 13.76 \\
\hline TAN CH1 128 & 14 & 1 & 2.0027 & 8.18 & 8.08 & 605 & 562 & .05 & 1.23 & 11.32 & 13.46 \\
\hline TAN CH1 128 & 15 & 1 & 2.0099 & 8.18 & 8.11 & 605 & 593 & .05 & 1.09 & 11.32 & 13.11 \\
\hline TAN CH1 128 & 4 & 2 & & 7.91 & 8.22 & 559 & 607 & .04 & .05 & 10.74 & 10.69 \\
\hline TAN CH1 128 & 8 & 2 & & 8.09 & 8.18 & 546 & 586 & .04 & .05 & 11.43 & 11.10 \\
\hline TAN CH1 128 & 12 & 2 & & 8.02 & 8.21 & 542 & 612 & .05 & .05 & 11.27 & 10.77 \\
\hline TAN CH1 128 & 16 & 2 & & 8.05 & 8.18 & 560 & 605 & .05 & .05 & 11.86 & 11.32 \\
\hline TAN CH1 128 & 17 & 3 & & 8.25 & 7.83 & 11 & 142 & .00 & .01 & .01 & .20 \\
\hline
\end{tabular}


Table 6. Basalt mass; initial and final aluminum, calcium, iron, magnesium, potassium, sodium, and strontium concentrations; initial and final specific conductance and $\mathrm{pH}$; and measured distribution coefficients of synthesized solutions - Continued

\begin{tabular}{|c|c|c|c|c|c|c|c|c|c|c|c|c|c|c|}
\hline $\begin{array}{l}\text { Sample } \\
\text { set }\end{array}$ & $\begin{array}{l}\text { Sample } \\
\text { number }\end{array}$ & $\begin{array}{c}\text { Sample } \\
\text { type }\end{array}$ & $\begin{array}{c}\text { Initial } \\
\text { Fe } \\
(\mathrm{mg} / \mathrm{L})\end{array}$ & $\begin{array}{c}\text { Final } \\
\mathrm{Fe} \\
(\mathrm{mg} / \mathrm{L})\end{array}$ & $\begin{array}{c}\text { Initial } \\
\mathbf{M g} \\
(\mathbf{m g} / \mathbf{L})\end{array}$ & $\begin{array}{c}\text { Final } \\
\text { Mg } \\
(\mathrm{mg} / \mathrm{L})\end{array}$ & $\begin{array}{c}\text { Initial } \\
\mathbf{K} \\
(\mathbf{m g} / \mathbf{L})\end{array}$ & $\begin{array}{c}\text { Final K } \\
(\mathrm{mg} / \mathrm{L})\end{array}$ & $\begin{array}{c}\text { Initial } \\
\mathrm{Na} \\
(\mathrm{mg} / \mathrm{L})\end{array}$ & $\begin{array}{c}\text { Final } \\
\mathrm{Na} \\
(\mathrm{mg} / \mathrm{L})\end{array}$ & $\begin{array}{c}\text { Initial } \\
\mathrm{Sr} \\
(\mathbf{m g} / \mathbf{L})\end{array}$ & $\begin{array}{c}\text { FinalSr } \\
(\mathrm{mg} / \mathrm{L})\end{array}$ & $\Delta \mathrm{Sr}$ & Sr Kd \\
\hline TAN CH1 128 & 1 & 1 & .01 & 2.05 & 1.99 & 3.26 & 3.51 & 3.96 & 110.2 & 109.1 & .00 & .06 & -.06 & -9.74 \\
\hline TAN CH 128 & 2 & 1 & .01 & 1.27 & 1.99 & 2.98 & 3.51 & 3.99 & 110.2 & 108.8 & .00 & .06 & -.05 & -9.72 \\
\hline TAN CH1 128 & 3 & 1 & .01 & 1.23 & 1.99 & 2.93 & 3.51 & 3.92 & 110.2 & 108.7 & .00 & .06 & -.05 & -9.68 \\
\hline TAN CH1 128 & 5 & 1 & .01 & .87 & 1.91 & 2.92 & 2.35 & 3.14 & 102.5 & 106.4 & 1.08 & .50 & .58 & 11.81 \\
\hline TAN CHI 128 & 6 & 1 & .01 & 1.58 & 1.91 & 3.21 & 2.35 & 3.12 & 102.5 & 106.4 & 1.08 & .51 & .58 & 11.39 \\
\hline TAN CH 128 & 7 & 1 & .01 & 1.03 & 1.91 & 2.94 & 2.35 & 3.10 & 102.5 & 102.8 & 1.08 & .49 & .59 & 12.25 \\
\hline TAN CH1 128 & 9 & 1 & .02 & 1.15 & 1.94 & 3.15 & 2.44 & 3.14 & 104.9 & 108.6 & 2.67 & 1.27 & 1.41 & 11.14 \\
\hline TAN CH1 128 & 10 & 1 & .02 & .88 & 1.94 & 2.92 & 2.44 & 3.18 & 104.9 & 106.0 & 2.67 & 1.22 & 1.45 & 11.90 \\
\hline TAN CH1 128 & 11 & 1 & .02 & 3.42 & 1.94 & 4.05 & 2.44 & 3.11 & 104.9 & 104.7 & 2.67 & 1.21 & 1.46 & 11.97 \\
\hline TAN CHI 128 & 13 & 1 & .01 & 2.73 & 1.92 & 4.12 & 2.40 & 3.07 & 106.9 & 107.6 & 5.44 & 2.65 & 2.79 & 10.53 \\
\hline TAN CH1 128 & 14 & 1 & .01 & .85 & 1.92 & 3.01 & 2.40 & 3.14 & 106.9 & 106.4 & 5.44 & 2.63 & 2.81 & 10.69 \\
\hline TAN CH1 128 & 15 & 1 & .01 & .67 & 1.92 & 2.87 & 2.40 & 3.00 & 106.9 & 105.5 & 5.44 & 2.60 & 2.84 & 10.84 \\
\hline TAN CH1 128 & 4 & 2 & .01 & .01 & 2.06 & 1.99 & 3.63 & 3.51 & 112.1 & 110.2 & .00 & .00 & .00 & \\
\hline TAN CHI 128 & 8 & 2 & .00 & .01 & 2.02 & 1.91 & 2.49 & 2.35 & 106.4 & 102.5 & 1.13 & 1.08 & .05 & \\
\hline TAN CH 128 & 12 & 2 & .00 & .02 & 2.02 & 1.94 & 2.59 & 2.44 & 106.1 & 104.9 & 2.80 & 2.67 & .13 & \\
\hline TAN CH1 128 & 16 & 2 & .00 & .01 & 2.03 & 1.92 & 2.52 & 2.40 & 109.6 & 106.9 & 5.73 & 5.44 & .29 & \\
\hline TAN CH1 128 & 17 & 3 & -.01 & .01 & .00 & .01 & .13 & .07 & -.8 & .1 & .00 & .01 &. .01 & \\
\hline
\end{tabular}


Table 6. Basalt mass; initial and final aluminum, calcium, iron, magnesium, potassium, sodium, and strontium concentrations; initial and final specific conductance and $\mathrm{pH}$; and measured distribution coefficients of synthesized solutions - Continued

\begin{tabular}{|c|c|c|c|c|c|c|c|c|c|c|c|}
\hline $\begin{array}{l}\text { Sample } \\
\text { set }\end{array}$ & $\begin{array}{l}\text { Sample } \\
\text { number }\end{array}$ & $\begin{array}{c}\text { Sample } \\
\text { type }\end{array}$ & $\begin{array}{c}\text { Basalt } \\
\text { mass } \\
\text { (grams) }\end{array}$ & Initial pH & Final pH & $\begin{array}{c}\text { Initial } \\
\text { conductivity } \\
(\mu \mathrm{S} / \mathrm{cm})\end{array}$ & $\begin{array}{c}\text { Final } \\
\text { conductivity } \\
(\mu \mathrm{S} / \mathrm{cm})\end{array}$ & $\begin{array}{c}\text { Initial Al } \\
\text { (mg/L) }\end{array}$ & $\begin{array}{c}\text { Final Al } \\
(\mathrm{mg} / \mathrm{L})\end{array}$ & $\begin{array}{c}\text { Initial Ca } \\
(\mathbf{m g} / \mathrm{L})\end{array}$ & $\begin{array}{c}\text { Final Ca } \\
(\mathrm{mg} / \mathrm{L})\end{array}$ \\
\hline TAN CH1 176 & 1 & 1 & 2.0048 & 8.02 & 8.18 & 662 & 627 & .04 & 1.25 & 10.10 & 11.96 \\
\hline TAN CH1 176 & 2 & 1 & 2.0096 & 8.02 & 8.12 & 662 & 461 & .04 & 1.32 & 10.10 & 11.70 \\
\hline TAN CH! 176 & 3 & 1 & 1.9956 & 8.02 & 8.14 & 662 & 389 & .04 & 2.75 & 10.10 & 13.26 \\
\hline TAN CHI 176 & 5 & 1 & 1.9975 & 8.09 & 8.26 & 574 & 588 & .05 & 1.55 & 11.07 & 13.28 \\
\hline TAN CHI 176 & 6 & 1 & 1.9967 & 8.09 & 8.28 & 574 & 532 & .05 & 1.13 & 11.07 & 12.73 \\
\hline TAN CH1 176 & 7 & 1 & 2.0046 & 8.09 & 8.30 & 574 & 622 & .05 & 1.95 & 11.07 & 14.14 \\
\hline TAN CHI 176 & 9 & 1 & 2.0033 & 8.16 & 8.25 & 610 & 623 & .05 & 1.03 & 10.73 & 12.80 \\
\hline TAN CH1 176 & 10 & 1 & 2.0009 & 8.16 & 8.25 & 610 & 657 & .05 & .94 & 10.73 & 12.48 \\
\hline TAN CH1 176 & 11 & 1 & 2.0029 & 8.16 & 8.17 & 610 & 605 & .05 & .99 & 10.73 & 12.49 \\
\hline TAN CHI 176 & 13 & 1 & 2.0045 & 8.13 & 8.20 & 571 & 608 & .05 & .85 & 11.18 & 13.10 \\
\hline TAN CH1 176 & 14 & 1 & 1.9969 & 8.13 & 8.25 & 571 & 633 & .05 & .90 & 11.18 & 13.30 \\
\hline TAN CH1 176 & 15 & 1 & 1.9952 & 8.13 & 8.27 & 571 & 567 & .05 & .84 & 11.18 & 13.04 \\
\hline TAN CH1 176 & 4 & 2 & & 7.91 & 8.02 & 559 & 662 & .04 & .04 & 10.74 & 10.10 \\
\hline TAN CH1 176 & 8 & 2 & & 8.09 & 8.09 & 546 & 574 & .04 & .05 & 11.43 & 11.07 \\
\hline TAN CHI 176 & 12 & 2 & & 8.02 & 8.16 & 542 & 610 & .05 & .05 & 11.27 & 10.73 \\
\hline TAN CH1 176 & 16 & 2 & & 8.05 & 8.13 & 560 & 571 & .05 & .05 & 11.86 & 11.18 \\
\hline TAN CH1 176 & 17 & 3 & & 8.25 & 7.89 & 11 & 187 & .00 & .01 & .01 & .20 \\
\hline
\end{tabular}


Table 6. Basalt mass; initial and final aluminum, calcium, iron, magnesium, potassium, sodium, and strontium concentrations; initial and final specific conductance and $\mathrm{pH}$; and measured distribution coefficients of synthesized solutions - Continued

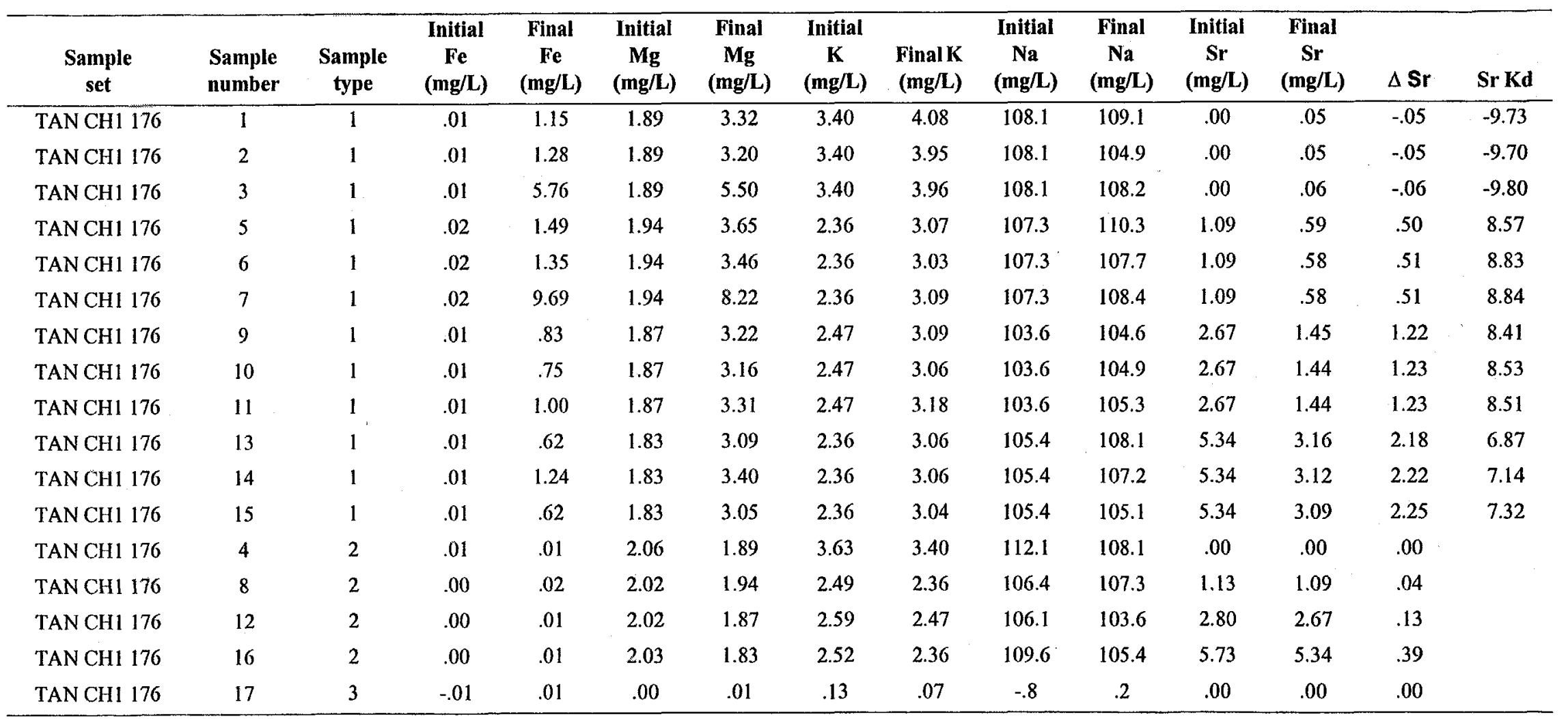


Table 7. Calculated and measured strontium distribution coefficients of basalt samples from the Idaho National Engineering and Environmental Laboratory

[Calculated strontium distribution coefficients $\left(\mathrm{K}_{d} \mathrm{~s}\right)$ are the slope of the linear isotherms; uncertainties are the standard error of the linear regression. Measured $\mathrm{K}_{\mathrm{d}}$ 's are the average of three replicate determinations reported to the largest whole number; uncertainties are the standard deviation of the three replicate determinations. Abbreviations: $\mathrm{mL} / \mathrm{g}$, milliliter per gram; $\mathrm{mg} / \mathrm{L}$, milligram per liter]

\begin{tabular}{|c|c|c|c|}
\hline Sample name & Calculated $K_{d}(\mathrm{~mL} / \mathrm{g})$ & $\begin{array}{c}\text { Initial strontium } \\
\text { concentration (mg/L) }\end{array}$ & Measured $K_{d}(\mathrm{~mL} / \mathrm{g})$ \\
\hline \multirow[t]{4}{*}{$123-14 a$} & $13.4 \pm 1.5$ & 0.0 & $-9.8 \pm 0.02$ \\
\hline & & 1.0 & $15.3 \pm 0.51$ \\
\hline & & 2.5 & $15.2 \pm 1.1$ \\
\hline & & 5.0 & $13.1 \pm 0.29$ \\
\hline \multirow[t]{4}{*}{$123-14 b$} & $7.4 \pm 0.96$ & .0 & $-9.6 \pm 0.02$ \\
\hline & & 1.0 & $8.8 \pm 0.34$ \\
\hline & & 2.5 & $8.3 \pm 0.34$ \\
\hline & & 5.0 & $7.3 \pm 0.18$ \\
\hline \multirow[t]{4}{*}{$123-64$} & $10.7 \pm 1.2$ & .0 & $-9.8 \pm 0.03$ \\
\hline & & 1.0 & $12.4 \pm 0.71$ \\
\hline & & 2.5 & $10.6 \pm 0.45$ \\
\hline & & 5.0 & $10.4 \pm 0.45$ \\
\hline \multirow[t]{4}{*}{$123-68$} & $7.7 \pm 1.4$ & .0 & $-9.7 \pm 0.03$ \\
\hline & & 1.0 & $8.8 \pm 0.71$ \\
\hline & & 2.5 & $9.1 \pm 0.45$ \\
\hline & & 5.0 & $7.5 \pm 0.45$ \\
\hline \multirow[t]{4}{*}{$123-130$} & $3.6 \pm 1.3$ & .0 & $-9.6 \pm 0.03$ \\
\hline & & 1.0 & $5.4 \pm 0.39$ \\
\hline & & 2.5 & $5.0 \pm 0.13$ \\
\hline & & 5.0 & $3.6 \pm 0.30$ \\
\hline \multirow[t]{4}{*}{$123-153$} & $4.0 \pm 0.79$ & .0 & $-9.6 \pm 0.00$ \\
\hline & & 1.0 & $5.6 \pm 0.23$ \\
\hline & & 2.5 & $4.5 \pm 0.19$ \\
\hline & & 5.0 & $4.0 \pm 0.18$ \\
\hline \multirow[t]{4}{*}{$123-156$} & $4.4 \pm 1.0$ & .0 & $-9.7 \pm 0.03$ \\
\hline & & 1.0 & $5.2 \pm 0.17$ \\
\hline & & 2.5 & $5.5 \pm 0.13$ \\
\hline & & 5.0 & $4.3 \pm 0.10$ \\
\hline
\end{tabular}


Table 7. Calculated and measured strontium distribution coefficients of basalt samples from the Idaho National Engineering and Environmental Laboratory--Continued

\begin{tabular}{|c|c|c|c|}
\hline Sample name & Calculated $K_{d}(\mathrm{~mL} / \mathrm{g})$ & $\begin{array}{l}\text { Initial strontium } \\
\text { concentration (mg/L) }\end{array}$ & Measured $K_{d}(\mathrm{~mL} / \mathrm{g})$ \\
\hline \multirow[t]{4}{*}{$123-172$} & $8.7 \pm 1.1$ & .0 & $-9.8 \pm 0.02$ \\
\hline & & 1.0 & $8.7 \pm 0.21$ \\
\hline & & 2.5 & $9.2 \pm 0.30$ \\
\hline & & 5.0 & $8.2 \pm 0.06$ \\
\hline \multirow[t]{4}{*}{$123-189$} & $4.1 \pm 0.95$ & .0 & $-9.6 \pm 0.01$ \\
\hline & & 1.0 & $5.5 \pm 0.18$ \\
\hline & & 2.5 & $5.0 \pm 0.08$ \\
\hline & & 5.0 & $4.0 \pm 0.11$ \\
\hline \multirow[t]{4}{*}{$123-209$} & $7.1 \pm 1.0$ & .0 & $-9.7 \pm 0.02$ \\
\hline & & 1.0 & $8.3 \pm 0.50$ \\
\hline & & 2.5 & $8.2 \pm 0.21$ \\
\hline & & 5.0 & $7.0 \pm 0.23$ \\
\hline \multirow[t]{4}{*}{$123-211 \mathrm{a}$} & $7.3 \pm 1.7$ & .0 & $-9.8 \pm 0.02$ \\
\hline & & 1.0 & $9.5 \pm 0.57$ \\
\hline & & 2.5 & $9.0 \pm 0.38$ \\
\hline & & 5.0 & $7.2 \pm 0.54$ \\
\hline \multirow[t]{4}{*}{$123-211 \mathrm{~b}$} & $7.8 \pm 1.1$ & .0 & $-9.8 \pm 0.01$ \\
\hline & & 1.0 & $8.4 \pm 0.44$ \\
\hline & & 2.5 & $8.3 \pm 0.24$ \\
\hline & & 5.0 & $7.5 \pm 0.20$ \\
\hline \multirow[t]{4}{*}{$123-221$} & $12.3 \pm 1.8$ & .0 & $-9.9 \pm 0.02$ \\
\hline & & 1.0 & $13.0 \pm 0.55$ \\
\hline & & 2.5 & $14.2 \pm 0.34$ \\
\hline & & 5.0 & $11.7 \pm 0.21$ \\
\hline \multirow[t]{4}{*}{ Wo-1-141 } & $23.3 \pm 1.4$ & .0 & $-9.8 \pm 0.03$ \\
\hline & & 1.0 & $20.1 \pm 0.32$ \\
\hline & & 2.5 & $22.8 \pm 0.77$ \\
\hline & & 5.0 & $21.9 \pm 0.96$ \\
\hline
\end{tabular}


Table 7. Calculated and measured strontium distribution coefficients of basalt samples from the Idaho National Engineering and Environmental Laboratory--Continued

\begin{tabular}{|c|c|c|c|}
\hline Sample name & Calculated $K_{d}(\mathrm{~mL} / \mathrm{g})$ & $\begin{array}{c}\text { Initial strontium } \\
\text { concentration (mg/L) }\end{array}$ & Measured $K_{d}(\mathrm{~mL} / \mathrm{g})$ \\
\hline \multirow[t]{4}{*}{ WO-1-146 } & $9.4 \pm 1.0$ & .0 & $-9.8 \pm 0.00$ \\
\hline & & 1.0 & $9.4 \pm 0.45$ \\
\hline & & 2.5 & $9.7 \pm 0.41$ \\
\hline & & 5.0 & $9.0 \pm 0.23$ \\
\hline \multirow[t]{4}{*}{ WO-2-185 } & $7.1 \pm 1.1$ & .0 & $-9.7 \pm 0.02$ \\
\hline & & 1.0 & $8.2 \pm 0.13$ \\
\hline & & 2.5 & $8.2 \pm 0.23$ \\
\hline & & 5.0 & $6.9 \pm 0.20$ \\
\hline \multirow[t]{4}{*}{ WO-2-186 } & $5.5 \pm 0.88$ & .0 & $-9.7 \pm 0.04$ \\
\hline & & 1.0 & $6.3 \pm 0.48$ \\
\hline & & 2.5 & $6.1 \pm 0.20$ \\
\hline & & 5.0 & $5.4 \pm 0.26$ \\
\hline \multirow[t]{4}{*}{ WO-2-397 } & $7.6 \pm 0.92$ & .0 & $-9.7 \pm 0.01$ \\
\hline & & 1.0 & $8.7=0.04$ \\
\hline & 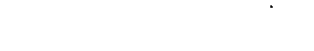 & 2.5 & $8.3=0.31$ \\
\hline & & 5.0 & $7.4 \pm 0.26$ \\
\hline \multirow[t]{4}{*}{ WO-2-400 } & $5.9 \pm 0.78$ & .0 & $-6.2 \pm 0.11$ \\
\hline & & 1.0 & $7.3 \pm 0.39$ \\
\hline & & 2.5 & $6.7 \pm 0.13$ \\
\hline & & 5.0 & $5.9 \pm 0.09$ \\
\hline \multirow[t]{4}{*}{ WO-2-520 } & $20.4 \pm 1.2$ & .0 & $-9.8 \pm 0.02$ \\
\hline & & 1.0 & $19.8 \pm 0.20$ \\
\hline & & 2.5 & $20.8 \pm 0.47$ \\
\hline & & 5.0 & $19.6 \pm 0.65$ \\
\hline \multirow[t]{4}{*}{ TAN CH1 83} & $9.4 \pm 1.2$ & .0 & $-9.8 \pm 0.01$ \\
\hline & & 1.0 & $10.1 \pm 0.38$ \\
\hline & & 2.5 & $10.3 \pm 0.29$ \\
\hline & & 5.0 & $9.1 \pm 0.26$ \\
\hline \multirow[t]{4}{*}{ TAN CH1 86} & $29.4 \pm 1.6$ & .0 & $-10.0 \pm 0.02$ \\
\hline & & 1.0 & $19.1 \pm 0.45$ \\
\hline & & 2.5 & $27.0 \pm 1.1$ \\
\hline & & 5.0 & $26.2 \pm 0.48$ \\
\hline
\end{tabular}


Table 7. Calculated and measured strontium distribution coefficients of basalt samples from the Idaho National Engineering and Environmental Laboratory--Continued

\begin{tabular}{cccc}
\hline Sample name & Calculated $\mathbf{K}_{\mathbf{d}}(\mathbf{m L} / \mathbf{g})$ & $\begin{array}{c}\text { Initial strontium } \\
\text { concentration }(\mathbf{m g} / \mathbf{l})\end{array}$ & Measured $\mathbf{K}_{\mathbf{d}}(\mathbf{m L} / \mathbf{g})$ \\
\hline TAN CH1 128 & $10.9 \pm 0.96$ & .0 & $-9.7 \pm 0.03$ \\
& 1.0 & $11.8 \pm 0.43$ \\
& 2.5 & $11.7 \pm 0.46$ \\
& 5.0 & $10.7 \pm 0.16$ \\
TAN CH1 176 & \multirow{2}{*}{$7.2 \pm 1.2$} & .0 & $-9.8 \pm 0.05$ \\
& & 1.0 & $8.8 \pm 0.15$ \\
& & 2.5 & $8.5 \pm 0.07$ \\
& & 5.0 & $7.1 \pm 0.22$ \\
\hline
\end{tabular}

